Prepared in cooperation with the Utah Department of Natural Resources and the U.S. Bureau of Land Management

\title{
Groundwater Model of the Great Basin Carbonate and Alluvial Aquifer System Version 3.0: Incorporating Revisions in Southwestern Utah and East Central Nevada
}

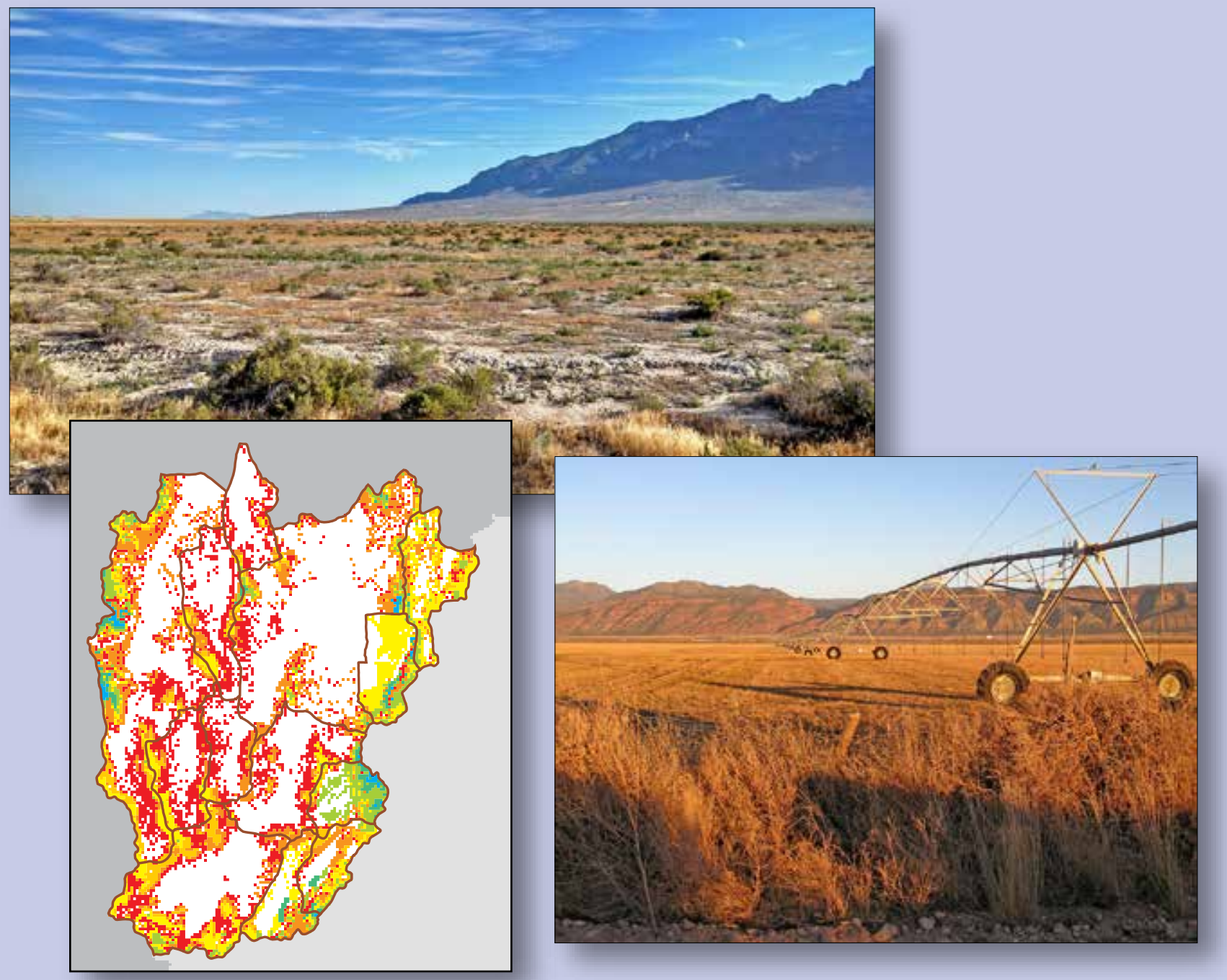

Scientific Investigations Report 2017-5072 
Cover photographs: Upper left, Tule Valley, just north of Highway 50 , looking north with the House Range on the right. Photograph by Phillip Gardner, U.S. Geological Survey, September 2013.

Lower right, Parowan Valley looking east toward the Red Cliffs. Photograph by Tom Marston, U.S. Geological Survey, November 2013. 


\section{Groundwater Model of the Great Basin Carbonate and Alluvial Aquifer System Version 3.0: Incorporating Revisions in Southwestern Utah and East Central Nevada}

By Lynette E. Brooks

Prepared in cooperation with the Utah Department of Natural Resources and the U.S. Bureau of Land Management

Scientific Investigations Report 2017-5072 


\title{
U.S. Department of the Interior \\ RYAN K. ZINKE, Secretary
}

\section{U.S. Geological Survey William H. Werkheiser, Acting Director}

\author{
U.S. Geological Survey, Reston, Virginia: 2017
}

For more information on the USGS - the Federal source for science about the Earth, its natural and living resources, natural hazards, and the environment-visit http://www.usgs.gov or call 1-888-ASK-USGS.

For an overview of USGS information products, including maps, imagery, and publications, visit http://store.usgs.gov/.

Any use of trade, firm, or product names is for descriptive purposes only and does not imply endorsement by the U.S. Government.

Although this information product, for the most part, is in the public domain, it also may contain copyrighted materials as noted in the text. Permission to reproduce copyrighted items must be secured from the copyright owner.

Suggested citation:

Brooks, L.E., 2017, Groundwater model of the Great Basin carbonate and alluvial aquifer system version 3.0: Incorporating revisions in southwestern Utah and east central Nevada: U.S. Geological Survey Scientific Investigations Report 2017-5072, 77 p., 2 appendixes, https://doi.org/10.3133/sir20175072.

ISSN 2328-0328 (online) 


\section{Contents}

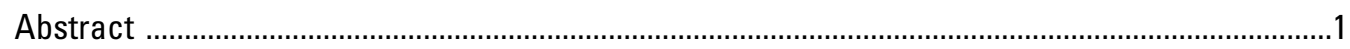

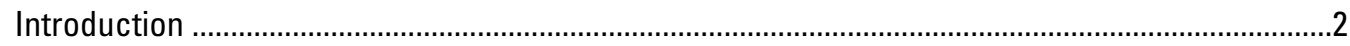

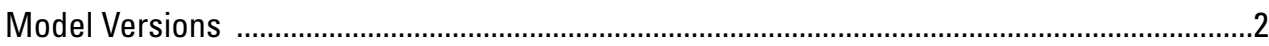

Hydrographic Areas and Model Focus Area ..................................................................

Previous Great Basin Carbonate and Alluvial Aquifer System Models ....................................

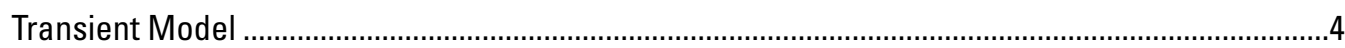

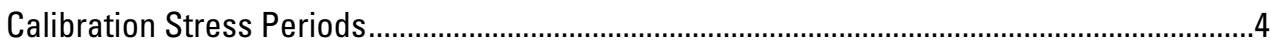

Storage Parameters and Transient Stresses .....................................................................6

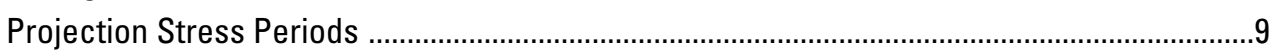

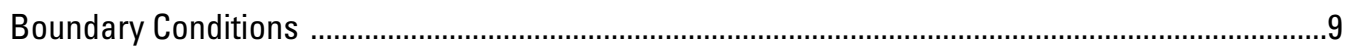

Specified-Flow Boundaries ............................................................................................

Recharge from Precipitation, Streams, and Irrigation ....................................................

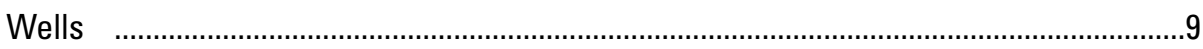

Head-Dependent Boundaries .......................................................................................

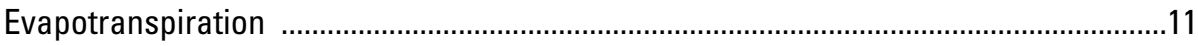

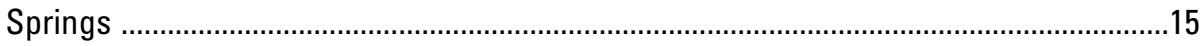

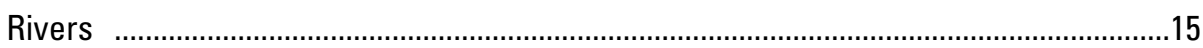

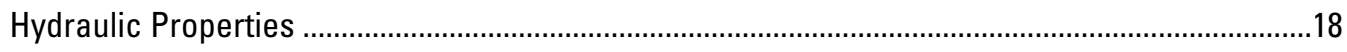

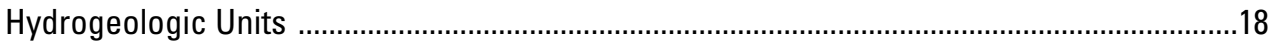

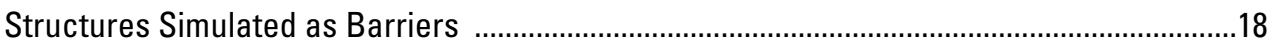

Observations Used in Model Calibration ................................................................................18

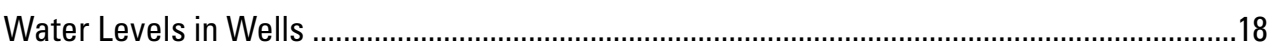

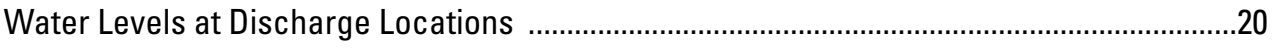

Groundwater Discharge and Uncertainty .......................................................................20

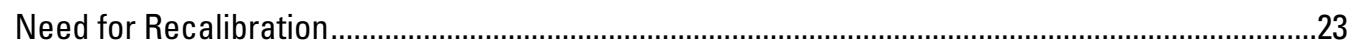

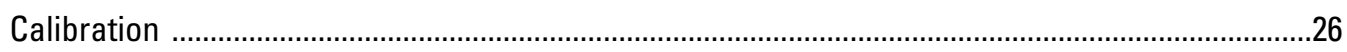

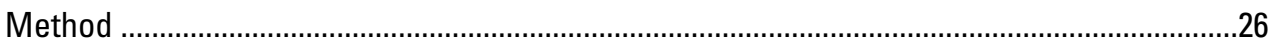

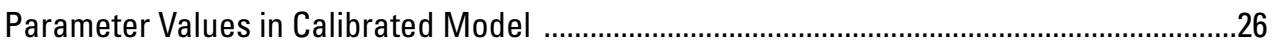

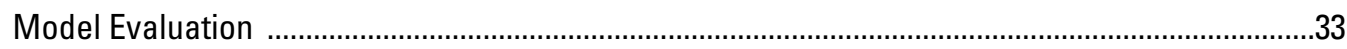

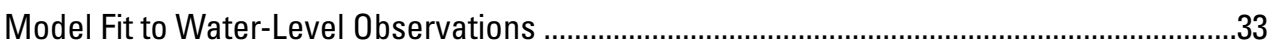

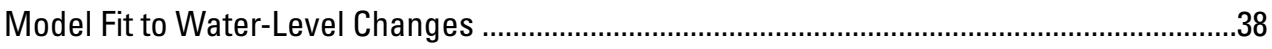

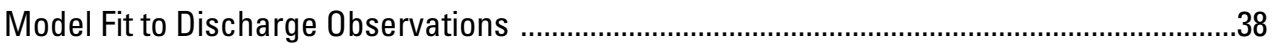

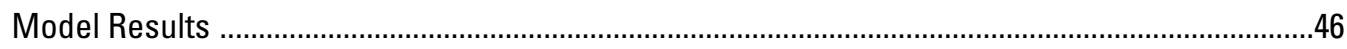

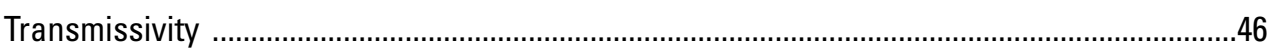

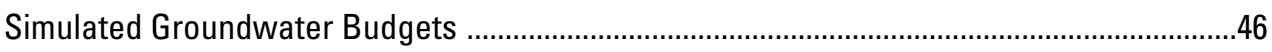

Pine and Wah Wah Valleys .........................................................................................

Effects of Groundwater Development ...................................................................50

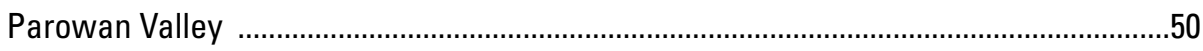

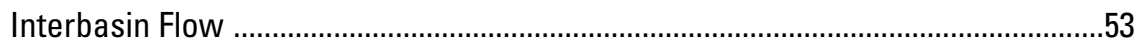

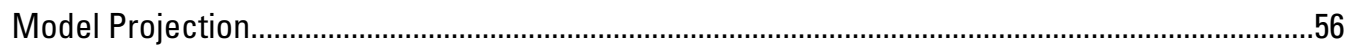

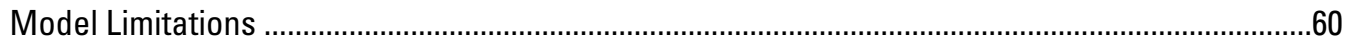

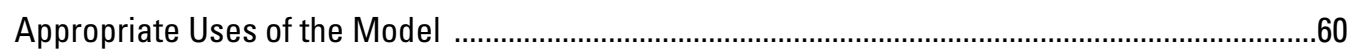

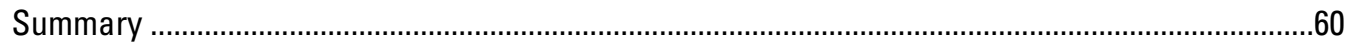


References

Appendix 1. Observations and Error Analysis Used in the Groundwater Model .65

Appendix 2. Model Parameter Statistics 68

\section{Figures}

1. Map showing location of model, valleys of interest, model focus area, and child model, Great Basin carbonate and alluvial aquifer system study area

2. Map showing altitude of the top of the model minus the simulated water level in layer 1 for stress period 1 of the GBCAAS v. 3.0 groundwater model, model focus area, Utah and Nevada

3. Graphs showing selected groundwater levels, precipitation, and well withdrawals in Parowan Valley, Utah, and stress periods of the GBCAAS v. 3.0 groundwater model, Great Basin carbonate and alluvial aquifer system study area, 1937 to 2015 .....7

4. Cross sections showing hydrogeologic units and model layers in the GBCAAS v. 3.0 groundwater model, Parowan Valley, Utah

5. Maps showing source of irrigation by surface water and rate of conceptual recharge from runoff and irrigation by surface water in Parowan Valley, Utah

6. Graph showing multiplier for conceptual recharge in Parowan Valley, Utah, for each transient stress period of the GBCAAS v. 3.0 groundwater model

7. Map showing distribution of simulated recharge for stress period 1 of the GBCAAS v. 3.0 groundwater model, model focus area, Utah and Nevada

8. Map showing location and deepest model layer of simulated well withdrawals in and near Parowan Valley, Utah, in the GBCAAS v. 3.0 groundwater model

9. Graphs showing conceptual and simulated well withdrawals in and near Parowan Valley, Utah, for each calibration stress period of the GBCAAS v. 3.0 groundwater model, 1940 to 2015

10. Map showing location and observed discharge by evapotranspiration in the GBCAAS v. 3.0 groundwater model, model focus area, Utah and Nevada

11. Map showing location and observed discharge to springs and rivers in the GBCAAS v. 3.0 groundwater model, model focus area, Utah and Nevada

12. Map showing location and conductance parameter of horizontal-flow barriers simulated using the Horizontal-Flow Barrier Package in the GBCAAS v. $3.0 \mathrm{~g}$ roundwater model, model focus area, Utah and Nevada

13. Map showing model-layer distribution of steady-state water-level observations at wells in the GBCAAS v. 3.0 groundwater model, model focus area, Utah and Nevada

14. Map showing model-layer distribution of transient water-level observations at wells in the GBCAAS v. 3.0 groundwater model, Parowan Valley, Utah

15. Map showing steady-state water-level residuals using the GBCAAS v. 2.0 groundwater model, model focus area, Utah and Nevada

16. Map showing steady-state evapotranspiration simulated by the GBCAAS v. 2.0 groundwater model, as percent of observed evapotranspiration, model focus area, Utah and Nevada

17. Graphs showing composite scaled sensitivities of final parameters in the GBCAAS v. 3.0 groundwater model, model focus area, Utah and Nevada 
18. Graphs showing values and linear confidence intervals of final parameters in the GBCAAS v. 3.0 groundwater model, model focus area, Utah and Nevada

19. Map showing simulated water-level change in layer 1 from GBCAAS v. 2.0 to the steady-state period of the GBCAAS v. 3.0 groundwater model, model focus area and surrounding areas, Utah and Nevada

20. Map showing simulated potentiometric surface and steady-state water-level residuals in the GBCAAS v. 3.0 groundwater model, model focus area, Utah and Nevada

21. Graphs showing weighted residuals in the GBCAAS v. 3.0 groundwater model, model focus area, Utah and Nevada

22. Map showing water-level residuals in the GBCAAS v 3.0 groundwater model for the first water level in the transient periods, Parowan Valley, Utah

23. Map showing location of selected wells used for comparison of measured and simulated water-level altitude in the transient periods of the GBCAAS v. 3.0 groundwater model, Parowan Valley, Utah

24. Graphs showing water-level altitudes simulated at the end of each stress period of the GBCAAS v. 3.0 groundwater model and measured water-level altitudes at selected wells during 1940 to 2013, Parowan Valley, Utah

25. Map showing simulated water-level change in layer 1 from the steady-state period to the end of stress period 16 of the GBCAAS v. 3.0 groundwater model, Parowan Valley, Utah

26. Map showing steady-state evapotranspiration simulated by the GBCAAS v. 3.0 groundwater model, as percent of observed evapotranspiration, model focus area, Utah and Nevada

27. Map showing steady-state simulated discharge to springs and rivers simulated by the GBCAAS v. 3.0 groundwater model, as percent of observed discharge, model focus area, Utah and Nevada

28. Map showing simulated transmissivity in the GBCAAS v. 3.0 groundwater model, model focus area, Utah and Nevada

29. Map showing simulated transmissivity in the GBCAAS $v 3.0$ groundwater model as a ratio of simulated transmissivity in the GBCAAS v. 2.0 groundwater model, model focus area, Utah and Nevada

30. Graphs showing estimates of recharge, Pine and Wah Wah Valleys, Utah

31. Graphs showing groundwater-budget components for the calibration stress periods of the GBCAAS v. 3.0 groundwater model, Parowan Valley, Utah, 1940 to 2013

32. Graphs showing groundwater-budget components for the projection stress periods of the GBCAAS v. 3.0 groundwater model, model focus area, Utah and Nevada

33. Map showing simulated water-level changes caused by reduced withdrawals in Parowan Valley and increased withdrawals in Pine and Wah Wah Valleys in the GBCAAS v. 3.0 groundwater model, Utah and Nevada 


\section{Tables}

1. Description of stress periods in the GBCAAS v. 3.0 groundwater model, Great Basin carbonate and alluvial aquifer system study area

2. Changes to previously used estimates of evapotranspiration in the GBCAAS v. 3.0 groundwater model, model focus area, Utah and Nevada

3. Summary statistics of observations in the GBCAAS v. 3.0 groundwater model, model focus area, Utah and Nevada

4. Horizontal hydraulic conductivity estimates for hydrogeologic units in the Death Valley regional groundwater flow system and the Great Basin carbonate and alluvial aquifer system study area

5. Estimates of properties describing parameter values for vertical anisotropy, horizontal-flow barriers, recharge, evapotranspiration, drains, rivers, withdrawals, and storage properties in the GBCAAS v. 3.0 groundwater model, Great Basin carbonate and alluvial aquifer system study area

6. Summary statistics for measures of model fit in the GBCAAS v. 3.0 groundwater model, model focus area, Utah and Nevada

7. Prior information statistics for selected parameters in the GBCAAS v. 3.0 groundwater model, Great Basin carbonate and alluvial aquifer system study area

8. Conceptual and steady-state simulated groundwater budgets for each hydrographic area in the model focus area, GBCAAS v. 1.0 and GBCAAS v. 3.0 groundwater models, Utah and Nevada

9. Comparison of interbasin flow simulated in the GBCAAS v. 1.0 and GBCAAS v. 3.0 groundwater models, model focus area, Utah and Nevada .....

10. Conceptual groundwater budget for November 2012 to October 2013 and simulated groundwater budget for stress periods 15 and 16 of the GBCAAS v. 3.0 groundwater model, Parowan Valley, Utah

11. Simulated groundwater budget for each calibration stress period of the GBCAAS v. 3.0 groundwater model, Parowan Valley, Utah

12. Reduction in natural discharge of at least 5 percent of initial discharge or rate of withdrawal as a result of withdrawals in Pine and Wah Wah Valleys during the projection simulation of the GBCAAS v. 3.0 groundwater model, model focus area and surrounding areas, Utah and Nevada

1-1. Selected springs not simulated explicitly in the GBCAAS v. 3.0 groundwater model, model focus area, Utah and Nevada

1-2. Springs added to the GBCAAS v. 3.0 groundwater model, model focus area, Utah and Nevada

1-3. Changes to springs simulated using the Drain Package in the GBCAAS v. 3.0 groundwater model, model focus area, Utah and Nevada

1-4. Changes to the riverbed hydraulic conductivity parameter and river observations in the GBCAAS v. 3.0 groundwater model, model focus area, Utah and Nevada

1-5. Well data, water-level observation, uncertainty, simulated values, and simulated residuals for observations of water levels in wells in the GBCAAS v. 3.0 groundwater model, Great Basin carbonate and alluvial aquifer system study area

1-6. Comparison of observed and simulated discharge for each discharge observation in the GBCAAS v. 3.0 groundwater model, Great Basin carbonate and alluvial aquifer system study area

2-1. Comparison of parameter values in different versions of the Great Basin carbonate and alluvial aquifer system groundwater model 
2-2. Model zones, multiplier arrays, and parameter values and statistics for recharge and withdrawals in the GBCAAS v. 3.0 groundwater model, model focus area, Utah and Nevada

2-3. Hydrogeologic zones, model zones, and parameter values and statistics for horizontal hydraulic conductivity of the confining units in the GBCAAS v. 3.0 groundwater model, model focus area, Utah and Nevada

2-4. Hydrogeologic zones, model zones, and parameter values and statistics for horizontal hydraulic conductivity of the carbonate aquifer units in the GBCAAS v. 3.0 groundwater model, model focus area, Utah and Nevada

2-5. Hydrogeologic zones, model zones, and parameter values and statistics for horizontal hydraulic conductivity of the volcanic and basin-fill units in the GBCAAS v. 3.0 groundwater model, model focus area, Utah and Nevada

2-6. Parameter values and statistics for horizontal-to-vertical anisotropy of all hydrogeologic units in the GBCAAS v. 3.0 groundwater model, model focus area, Utah and Nevada

2-7. Parameter values and statistics for evapotranspiration conductance or rate multiplier, drain leakance, and river conductivity in the GBCAAS v. 3.0 groundwater model, model focus area, Utah and Nevada

2-8. Parameter values and statistics for the hydraulic characteristic of horizontal-flow barriers in the GBCAAS v. 3.0 groundwater model, model focus area, Utah and Nevada

2-9. Parameter values and statistics for storage properties in the GBCAAS v. 3.0 groundwater model, model focus area, Utah and Nevada 


\section{Conversion Factors and Datums}

Inch/Pound to International System of Units

\begin{tabular}{|c|c|c|}
\hline Multiply & By & To obtain \\
\hline \multicolumn{3}{|c|}{ Length } \\
\hline foot $(\mathrm{ft})$ & 0.3048 & meter $(\mathrm{m})$ \\
\hline mile (mi) & 1.609 & kilometer $(\mathrm{km})$ \\
\hline \multicolumn{3}{|c|}{ Area } \\
\hline acre & 4,047 & square meter $\left(\mathrm{m}^{2}\right)$ \\
\hline acre & 0.4047 & hectare (ha) \\
\hline acre & 0.04047 & square hectometer $\left(\mathrm{hm}^{2}\right)$ \\
\hline acre & 0.004047 & square kilometer $\left(\mathrm{km}^{2}\right)$ \\
\hline square mile $\left(\mathrm{mi}^{2}\right)$ & 259.0 & hectare (ha) \\
\hline square mile $\left(\mathrm{mi}^{2}\right)$ & 2.590 & square kilometer $\left(\mathrm{km}^{2}\right)$ \\
\hline \multicolumn{3}{|c|}{ Volume } \\
\hline acre-foot (acre-ft) & 1,233 & cubic meter $\left(\mathrm{m}^{3}\right)$ \\
\hline acre-foot (acre-ft) & 0.001233 & cubic hectometer $\left(\mathrm{hm}^{3}\right)$ \\
\hline \multicolumn{3}{|c|}{ Flow rate } \\
\hline acre-foot per year (acre-ft/yr) & 1,233 & cubic meter per year $\left(\mathrm{m}^{3} / \mathrm{yr}\right)$ \\
\hline acre-foot per year (acre-ft/yr) & 0.001233 & cubic hectometer per year $\left(\mathrm{hm}^{3} / \mathrm{yr}\right)$ \\
\hline foot per year (ft/yr) & 0.3048 & meter per year $(\mathrm{m} / \mathrm{yr})$ \\
\hline cubic foot per day $\left(\mathrm{ft}^{3} / \mathrm{d}\right)$ & 0.02832 & cubic meter per day $\left(\mathrm{m}^{3} / \mathrm{d}\right)$ \\
\hline gallon per minute (gal/min) & 0.06309 & liter per second $(\mathrm{L} / \mathrm{s})$ \\
\hline gallon per day (gal/d) & 0.003785 & cubic meter per day $\left(\mathrm{m}^{3} / \mathrm{d}\right)$ \\
\hline million gallons per day (Mgal/d) & 0.04381 & cubic meter per second $\left(\mathrm{m}^{3} / \mathrm{s}\right)$ \\
\hline inch per year (in/yr) & 25.4 & millimeter per year $(\mathrm{mm} / \mathrm{yr})$ \\
\hline \multicolumn{3}{|c|}{ Hydraulic conductivity } \\
\hline foot per day (ft/d) & 0.3048 & meter per day $(\mathrm{m} / \mathrm{d})$ \\
\hline \multicolumn{3}{|c|}{ Transmissivity* $^{*}$} \\
\hline foot squared per day $\left(\mathrm{ft}^{2} / \mathrm{d}\right)$ & 0.09290 & meter squared per day $\left(\mathrm{m}^{2} / \mathrm{d}\right)$ \\
\hline \multicolumn{3}{|c|}{ Leakance $^{* *}$} \\
\hline per day $(/ d)$ & 1 & per day $(/ d)$ \\
\hline
\end{tabular}

Vertical coordinate information is referenced to the North American Vertical Datum of 1988 (NAVD 88).

Horizontal coordinate information is referenced to the North American Datum of 1983 (NAD 83). Altitude, as used in this report, refers to distance above the vertical datum.

*Transmissivity: The standard unit for transmissivity is cubic foot per day per square foot times foot of aquifer thickness [(ft $\left.\left.\mathrm{ft}^{3} / \mathrm{d}\right) / \mathrm{ft}^{2}\right] \mathrm{ft}$. In this report, the mathematically reduced form, foot squared per day $\left(\mathrm{ft}^{2} / \mathrm{d}\right)$, is used for convenience.

**Leakance: The standard unit for leakance is foot per day per foot [(ft/d)/ft]. In this report, the mathematically reduced form, per day $(/ d)$, is used for convenience. 


\section{Abbreviations}

BCM Basin characterization model to estimate recharge

ET Evapotranspiration

ETg Evapotranspiration from groundwater

GBCAAS Great Basin carbonate and alluvial aquifer system

GIS Geographic information system

HA Hydrographic area

HFB Horizontal-flow barrier

HGU Hydrogeologic unit

NED Land surface as defined by the 1-arc second (about 30 meters) National Elevation Dataset

NWIS U.S. Geological Survey National Water Information System

USGS U.S. Geological Survey 


\section{Wells by the Cadastral System of Land Subdivision}

The well-numbering system used in Utah is based on the Cadastral system of land subdivision. The well-numbering system is familiar to most water users in Utah, and the well number shows the location of the well by quadrant, township, range, section, and position within the section. Well numbers for most of the State are referenced to the Salt Lake Base Line and Meridian. This system is also used for spring numbers.

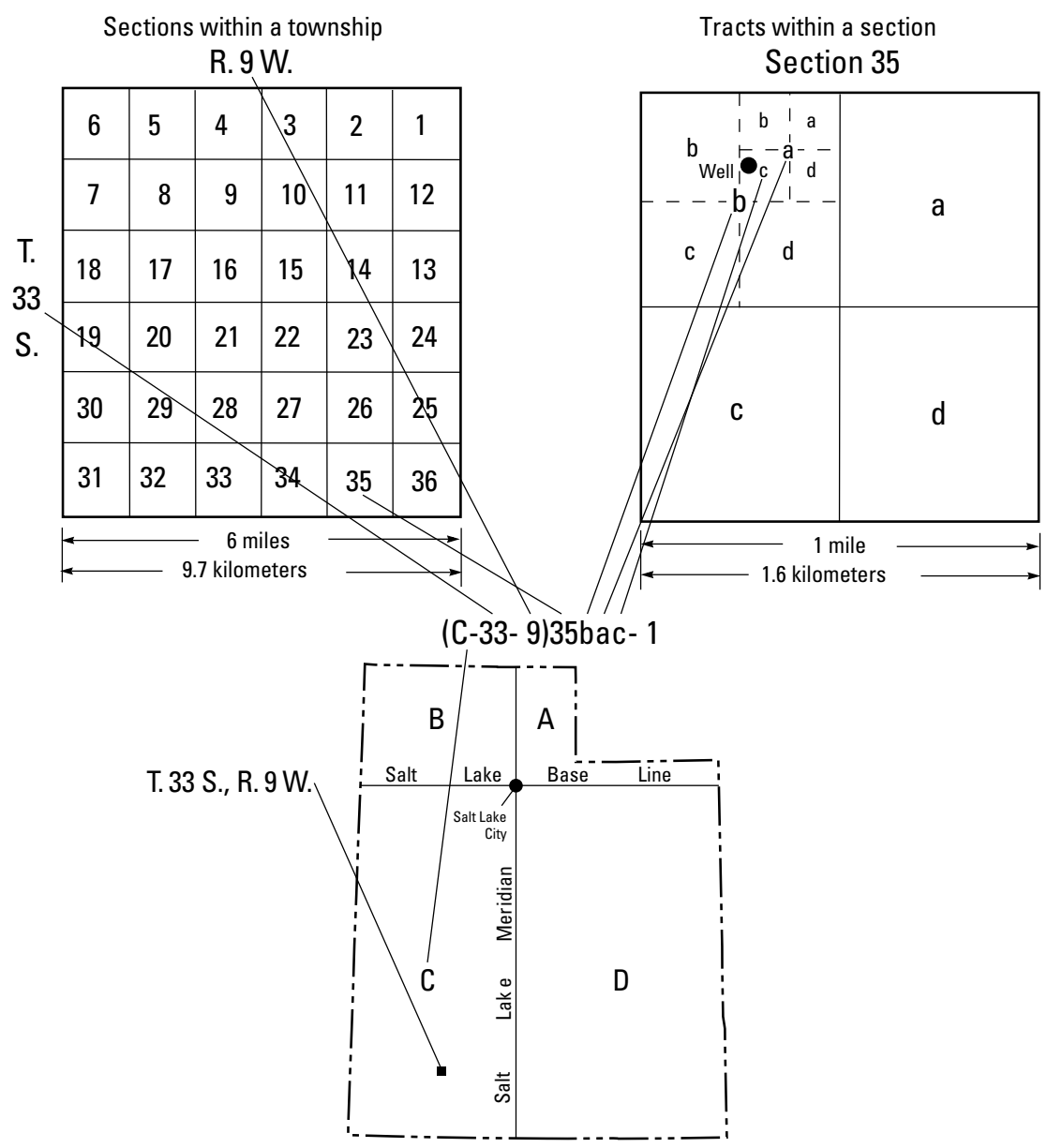

\section{Surface-Water Sites-Downstream Order and Station Number}

Since October 1, 1950, hydrologic-station records in U.S. Geological Survey reports have been listed in order of downstream direction along the mainstem. All stations on a tributary entering upstream from a mainstem station are listed before that station. A station on a tributary entering between two mainstem stations is listed between those stations.

As an added means of identification, each hydrologic station and partial-record station has been assigned a station number. These station numbers are in the same downstream order used in this report. In assigning a station number, no distinction is made between partial-record stations and other stations; therefore, the station number for a partial-record station indicates downstream order position in a list comprising both types of stations. Gaps are consecutive. The complete 8-digit (or 10-digit) number for each station such as 10125600, which appears just to the left of the station name, includes a 2-digit part number "10" plus the 6-digit (or 8-digit) downstream order number "125600." In areas of high station density, an additional two digits may be added to the station identification number to yield a 10-digit number. The stations are numbered in downstream order as described above between stations of consecutive 8-digit numbers. 


\title{
Groundwater Model of the Great Basin Carbonate and Alluvial Aquifer System Version 3.0: Incorporating Revisions in Southwestern Utah and East Central Nevada
}

\author{
By Lynette E. Brooks
}

\section{Abstract}

The groundwater model described in this report is a new version of previously published steady-state numerical groundwater flow models of the Great Basin carbonate and alluvial aquifer system, and was developed in conjunction with U.S. Geological Survey studies in Parowan, Pine, and Wah Wah Valleys, Utah. This version of the model is GBCAAS v. 3.0 and supersedes previous versions. The objectives of the model for Parowan Valley were to simulate revised conceptual estimates of recharge and discharge, to estimate simulated aquifer storage properties and the amount of reduction in storage as a result of historical groundwater withdrawals, and to assess reduction in groundwater withdrawals necessary to mitigate groundwater-level declines in the basin. The objectives of the model for the area near Pine and Wah Wah Valleys were to recalibrate the model using new observations of groundwater levels and evapotranspiration of groundwater; to provide new estimates of simulated recharge, hydraulic conductivity, and interbasin flow; and to simulate the effects of proposed groundwater withdrawals on the regional flow system. Meeting these objectives required the addition of 15 transient calibration stress periods and 14 projection stress periods, aquifer storage properties, historical withdrawals in Parowan Valley, and observations of water-level changes in Parowan Valley.

Recharge in Parowan Valley and withdrawal from wells in Parowan Valley and two nearby wells in Cedar City Valley vary for each calibration stress period representing conditions from March 1940 to November 2013. Stresses, including recharge, are the same in each stress period as in the steadystate stress period for all areas outside of Parowan Valley. The model was calibrated to transient conditions only in Parowan Valley. Simulated storage properties outside of Parowan Valley were set the same as the Parowan Valley properties and are not considered calibrated.

Model observations in GBCAAS v. 3.0 are groundwater levels at wells and discharge locations; water-level changes; and discharge to springs, evapotranspiration of groundwater, rivers, and lakes. All observations in the model outside of Parowan Valley are considered to represent steady-state conditions. Composite scaled sensitivities indicate the observations of discharge to rivers and springs provide more information about model parameters in the model focus area than do water-level observations. Water levels and water-level changes, however, provide the only information about specific yield and specific storage parameters and provide more information about recharge and withdrawals in Parowan Valley than any other observation group.

Comparisons of simulated water levels and measured water levels in Parowan Valley indicated that the model fits the overall trend of declining water levels and provides reasonable estimates of long-term reduction in storage and of storage changes from 2012 to 2013. The conceptual and simulated groundwater budgets for Parowan Valley from November 2012 to November 2013 are similar, with recharge of about 20,000 acre-feet and discharge of about 45,000 acre-ft. In the simulation, historical withdrawals averaging about 28,000 acre-feet per year (acre-ft/yr) cause major changes in the groundwater system in Parowan Valley. These changes include the cessation of almost all natural discharge in the valley and the long-term removal of water from storage.

Simulated recharge in Pine Valley of 11,000 acre-ft/yr and in Wah Wah Valley of 3,200 acre-ft/yr is substantially less in GBCAAS v. 3.0 than that simulated by previous model versions. In addition, the valleys have less simulated inflow from and outflow to other hydrographic areas than were simulated by previous model versions. The effects of groundwater development in these valleys, however, are independent of the amount of water recharging in and flowing through the valleys. Groundwater withdrawals in Pine and Wah Wah Valleys will decrease groundwater storage (causing drawdown) until discharge in surrounding areas and mountain springs around the two valleys is reduced by the rate of withdrawal.

The model was used to estimate that reducing withdrawals in Parowan Valley from 35,000 to about 22,000 acre-ft/yr would likely stabilize groundwater levels in the valley if recharge varies as it did from about 1950 to 2012. The model was also used to demonstrate that withdrawals of 15,000 acre-ft/yr from Pine Valley and 6,500 acre-ft/yr from Wah Wah Valley could ultimately cause long-term steadystate water-level declines of about 1,900 feet near the withdrawal wells and of more than 5 feet in an area of about 10,500 square miles. The timing of drawdown and capture and the ultimate amount of drawdown are dependent on the proximity to areas of simulated natural groundwater discharge, simulated transmissivity, and simulated storage properties. The model projections are a representation of possible effects. 


\section{Introduction}

The groundwater model described in this report was developed in conjunction with U.S. Geological Survey (USGS) studies in Parowan, Pine, and Wah Wah Valleys, Utah (fig. 1). Conceptual recharge, groundwater movement, and discharge are described in Marston (2017) for Parowan Valley, by Philip Gardner (U.S. Geological Survey, written commun., July 21, 2016) for Pine and Wah Wah Valleys, and by Heilweil and Brooks (2011) for other parts of the study area. The scope of the USGS studies, as related to the groundwater model, was limited to specific objectives in each study area. The objectives of the model for Parowan Valley were as follows: (1) to simulate revised conceptual estimates of recharge from irrigation and discharge to evapotranspiration (ETg), springs, and wells; (2) to estimate aquifer storage properties and the amount of reduction in storage that results from historical groundwater withdrawals; and (3) to assess the reduction in groundwater withdrawals necessary to mitigate groundwaterlevel declines in the basin. Meeting these objectives required adding transient stress periods, aquifer storage properties, historical withdrawals, and observations of water-level changes to the model. The objectives of the model for the area near Pine and Wah Wah Valleys were as follows: (1) to recalibrate the model using recent observations of groundwater levels and ETg; (2) to provide revised estimates of simulated recharge, hydraulic conductivity, and interbasin flow; and (3) to simulate the effects of proposed groundwater withdrawals on the regional flow system.

The model is a new version of previously published steady-state numerical groundwater flow models of the Great Basin carbonate and alluvial aquifer system (GBCAAS). The purpose of this report is to provide documentation of the changes in the model and model results for this version. Hydrogeology, model construction, model observations, and calibration techniques are discussed more fully in Brooks and others (2014) and Stolp and others (2017). Additional model details are also available in the model files (Brooks, 2017).

\section{Model Versions}

This version of the model is GBCAAS v. 3.0 and supersedes previous versions. The original version of the model (Brooks and others, 2014) used MODFLOW-2005 and is called GBCAAS v. 1.0 in this report. A second version (GBCAAS v. 2.0) of the model (Stolp and others, 2017) included local grid refinement in Malad-Lower Bear River Area (HA 273) in northern Utah (fig. 1) using MODFLOWLGR (Mehl and Hill, 2013). GBCAAS v. 2.0 includes a child model that incorporates Malad-Lower Bear River Area and a parent model that incorporates the rest of the GBCAAS area. Only minor modifications were made in the parent model, and these were only near the child model. As a result, most of GBCAAS v. 2.0 is the same as GBCAAS v. 1.0. Although the changes in GBCAAS v. 2.0 did not affect the study area for this report, GBCAAS v. 2.0 was used as the base model for GBCAAS v. 3.0 so that one version of the model incorporates all refinements that improve the entire model. The model data release of GBCAAS v. 3.0 (Brooks, 2017) includes files for both the child and parent models. GBCAAS v. 3.0 must be run using MODFLOW-LGR.

In this report, model parameters and values are compared with those in GBCAAS v. 1.0 and GBCAAS v. 2.0. Typically, the comparison is with "previous versions," but the comparison is with GBCAAS v. 1.0 if the referenced values are reported in Brooks and others (2014) and with GBCAAS v. 2.0 if discussing starting conditions for GBCAAS v. 3.0. Many of the details of model construction and calibration for GBCAAS v. 1.0 are not included in this report; Brooks and others (2014) provide the background material. Because the changes made in GBCAAS v. 2.0 did not affect the study area described in this report, the documentation for GBCAAS v. 2.0 (Stolp and others, 2017) is not needed as background material. This report discusses only the parent model, and no changes were made from GBCAAS v. 2.0 to the child model (other than adding transient stress periods) or to the parent model near the child model.

\section{Hydrographic Areas and Model Focus Area}

This report uses hydrographic areas (HAs) to describe locations, name model observations, and present groundwater budgets. The terminology is consistent with previously published reports about the Great Basin carbonate and alluvial aquifer system (Heilweil and Brooks, 2011; Brooks and others, 2014). Most HAs represent a single watershed, including basin fill and the adjacent mountain blocks up to the topographic divide (Harrill and Prudic, 1998); some divisions, however, are arbitrary (Welch and others, 2007). This study utilizes the naming and numbering convention for HAs used by Harrill and others (1988).

Because the HAs in the area of model revisions are hydraulically connected (Heilweil and Brooks, 2011, pl. 2; Brooks and others, 2014, fig. A3-1 and table A3-3), the model focus area (fig. 1) for recalibration was extended to several HAs, not just Parowan (HA 281), Pine (HA 255), and Wah Wah (HA 256) Valleys. Understanding flow in and between Snake Valley (HA 254), Pine Valley (HA 255), Wah Wah Valley (HA 256), Tule Valley (HA 257), and Sevier Desert (HA 287) is critical to understanding groundwater flow in this area and the effects of groundwater withdrawals. The model focus area is in the southern part of the Great Salt Lake Desert model region defined by Brooks and others (2014, fig. 43). The extent of the focus area was chosen to minimize the area of revisions, but to still incorporate most of the area that may contribute water to Sevier Desert, Tule Valley, and Fish Springs Flat (HA 258; Heilweil and Brooks, 2011, pl. 2). 


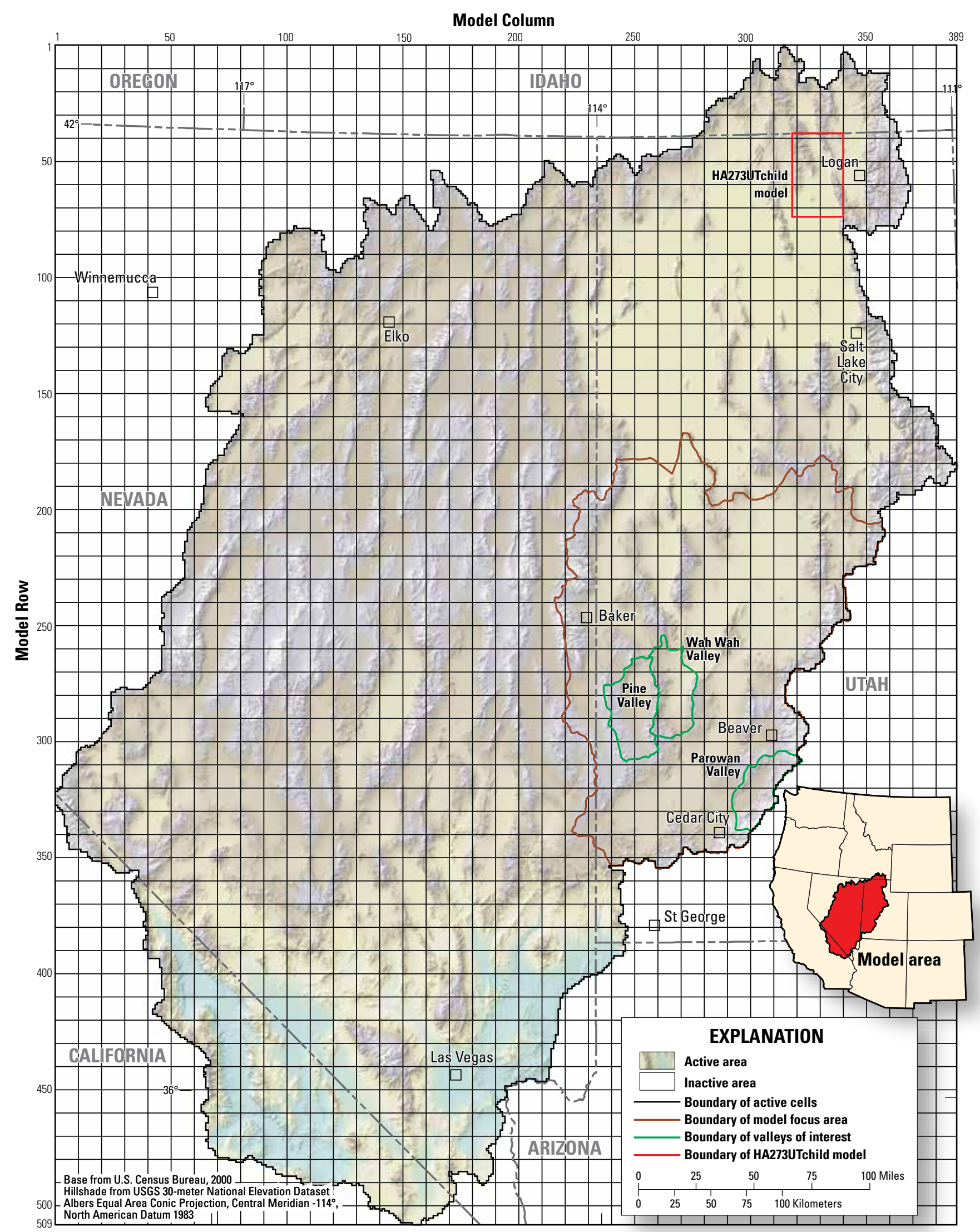

Figure 1. Location of model, valleys of interest, model focus area, and child model, Great Basin carbonate and alluvial aquifer system study area. 


\section{Previous Great Basin Carbonate and Alluvial Aquifer System Models}

The GBCAAS v. 1.0 model (Brooks and others, 2014) was constructed using MODFLOW-2005 (Harbaugh, 2005) and simulates the groundwater system in about 110,000 square miles $\left(\mathrm{mi}^{2}\right)$ in Utah, Nevada, California, Idaho, and Arizona (fig. 1). Model construction, discretization, recharge, discharge, and MODFLOW Packages used are described in Brooks and others (2014) and are summarized here. The model simulates steady-state pre-pumping conditions and consists of 509 rows, 389 columns, and 8 layers. Model grid rows are oriented in an east-west direction, and model grid columns are oriented in a north-south direction. Model grid spacing is 1 mile (mi) in both the north-south and east-west directions. Although the top of the groundwater system is unconfined, all model layers were designated as confined because simulating layer 1 as confined is more numerically stable and efficient (Brooks and others, 2014, p. 19). For a steady-state model, the only implication of this is that the transmissivity of the layer does not change with change in simulated water level. Simulating layer 1 as confined is a reasonable approximation if the simulated saturated thickness is close to the specified saturated thickness (Reilly and Harbaugh, 2004, p. 15). The top of the model and thicknesses of layers were adjusted during calibration of all model versions to allow the top of the model to be close to the altitude of simulated water levels (fig. 2), to ensure that the bottom of layer 1 was lower than simulated heads, and to ensure that the top of layer 1 was not above land surface at the center of the cell, as defined by the 1-arc second (about 30 meters) National Elevation Dataset (NED) available from the USGS (U.S. Geological Survey EROS Data Center, 1999). The thickness of layers 2 through 6 was also adjusted so that no layer was less than 10 feet (ft) thick.

The model incorporates unconsolidated basin fill and consolidated rock as a connected system, where most recharge is on consolidated rock in the mountains, and most discharge is ETg in the basins. The model simulates recharge from precipitation and from irrigation with surface water, but irrigation recharge was assigned to generalized areas within each HA where irrigation from surface water is simulated, not to specific fields or crops (Brooks and others, 2014, p. 20). Recharge from rivers and canals is not explicitly simulated, but the estimated amount is applied as areal recharge to selected cells in each HA. The model simulates groundwater discharge to ETg and to selected springs, rivers, and lakes. Numerical instability prevented the use of the Evapotranspiration Package (Harbaugh, 2005, p. 8-46 to 8-48), and ETg was simulated using the Drain Package (Harbaugh, 2005, p. 8-43 to 8-44; Brooks and others, 2014, p. 27). Impermeable boundaries were assumed below an altitude of $-12,000 \mathrm{ft}$ and along all lateral boundaries, except for two small areas that are far from the model focus area of this report (Brooks and others, 2014, pl. 1).
The nine hydrogeologic units (HGUs) described in Sweetkind and others (2011a) were the basis for assigning horizontal hydraulic conductivity and vertical anisotropy to the model layers. The HGUs are simulated by using the HydrogeologicUnit Flow (HUF) Package (Anderman and Hill, 2000, 2003) of MODFLOW-2005, which can represent the complexities of the geology (Brooks and others, 2014, fig. 3). Hydrogeologic structures that act as barriers to groundwater flow are simulated by using the Horizontal-Flow Barrier (HFB) Package (Harbaugh, 2005, p. 5-21 to 5-22).

\section{Transient Model}

An objective of the model for Parowan Valley (HA 281) was to estimate storage properties and the reduction in aquifer storage that results from groundwater withdrawals. Specifically, the model was to provide an estimate of the reduction in storage from November 2012 to November 2013 during a period of streamflow, withdrawal, and water-level data collection. This objective of the model required adding transient stress periods to the steady-state period used in previous versions of the model.

\section{Calibration Stress Periods}

Because the annual variation in location and amount of historical withdrawals from each well and of irrigation recharge in Parowan Valley (HA 281) was not known, it could not be simulated. These local variations could have caused observed annual water-level changes that are more specific than can be simulated with this model. For this reason, instead of annual stress periods, 15 transient stress periods representing multi-year changes in measured water level in multiple wells, precipitation, and historical groundwater withdrawals were defined (table 1, fig. 3). This method provided enough variation to calibrate to transient conditions of recharge and groundwater withdrawals in Parowan Valley (HA 281) from March 1950 to November 2013, but provided some smoothing of the unknown variation in local annual stresses. Water levels have been monitored by the USGS in Parowan Valley since the 1930s and are typically measured in March. Model stress periods were typically delineated from the beginning of March to the end of February (table 1). To account for the intensive data collection during November 2012 to November 2013, stress periods 14 to 16 have shorter lengths. Stress period 15 is from November 2012 to February 2013, and no pumping or recharge is simulated. During this time of the year, municipal water is mostly supplied by springs, and precipitation is typically snow, so recharge does not occur until snowmelt in spring. 


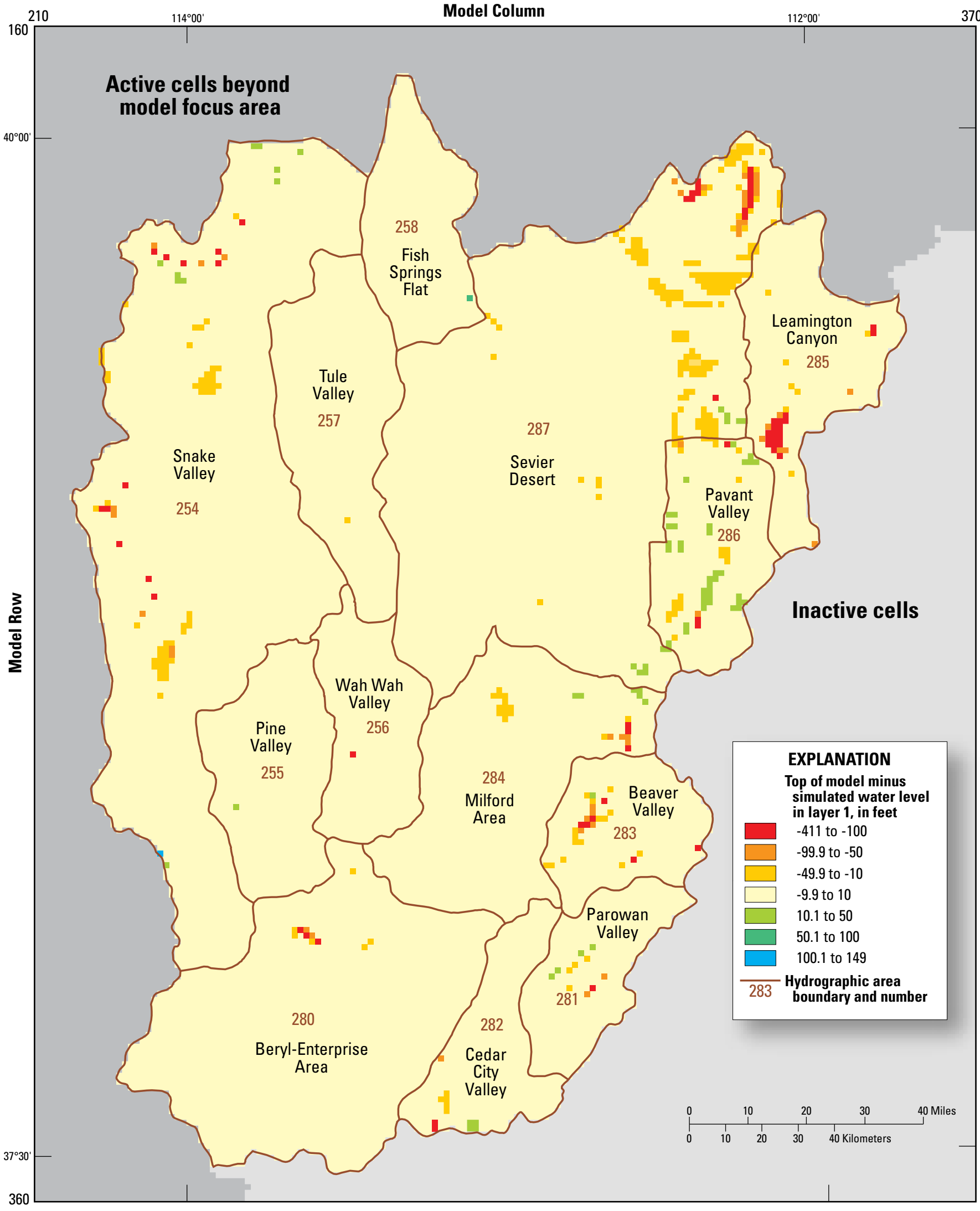

Figure 2. Altitude of the top of the model minus the simulated water level in layer 1 for stress period 1 of the GBCAAS v. 3.0 groundwater model, model focus area, Utah and Nevada. 


\section{Storage Parameters and Transient Stresses}

Parameters defining specific yield for model layer 1 and specific storage for all HGUs were added to the HUF Package. Although the top model layer is simulated as confined, the parameter definition allows the top layer to be represented using specific yield, not specific storage (Anderman and Hill, 2003, p. 4). Because all layers are confined, simulated transmissivity is not reduced when the simulated water levels decline. Because the declines are small in relation to total simulated thickness (fig. 4), however, the effect is likely insubstantial. Any possible effects are limited to Parowan Valley (HA 281) and the projection simulation.
Simulated storage properties outside of Parowan Valley were set the same as the Parowan Valley properties and are not considered calibrated. The model may not accurately represent transient conditions outside of Parowan Valley. Because of improvements in calibration to steady-state conditions, however, this model should be used instead of previous versions (Brooks and others, 2014; Stolp and others, 2017) to simulate the Great Basin carbonate and alluvial aquifer system during pre-development steady-state conditions, and can be used for management guidance with the limitations described.

Stresses, including recharge, are the same in each stress period as in the steady-state stress period for all areas outside of Parowan Valley (HA 281), and simulated water-levels do

Table 1. Description of stress periods in the GBCAAS v. 3.0 groundwater model, Great Basin carbonate and alluvial aquifer system study area.

\begin{tabular}{|c|c|c|c|c|}
\hline \multicolumn{5}{|c|}{ Reason for stress period delination } \\
\hline \multicolumn{5}{|c|}{ Calibration periods } \\
\hline & Stress period & Dates simulated & $\begin{array}{l}\text { General water-level trend in } \\
\text { Parowan Valley, Utah }\end{array}$ & $\begin{array}{c}\text { Precipitation in } \\
\text { Parowan Valley, Utah }\end{array}$ \\
\hline 1 & steady-state & March 1940 to February 1950 & - & - \\
\hline 2 & transient & March 1950 to February 1961 & Decline & Below average \\
\hline 3 & transient & March 1961 to February 1965 & Flat or decline less steeply & Slightly below average \\
\hline 4 & transient & March 1965 to February 1976 & Flat or decline less steeply & Slightly above average \\
\hline 5 & transient & March 1976 to February 1979 & Steep decline & Below average \\
\hline 6 & transient & March 1979 to February 1983 & Flat or increase & Above average \\
\hline 7 & transient & March 1983 to February 1985 & Increase & Above average \\
\hline 8 & transient & March 1985 to February 1989 & Variable, mostly flat or decline & Above average \\
\hline 9 & transient & March 1989 to February 1995 & Decline & Average \\
\hline 10 & transient & March 1995 to February 1999 & Variable & Average \\
\hline 11 & transient & March 1999 to February 2005 & Steep decline & Below average \\
\hline 12 & transient & March 2005 to February 2010 & Variable & Average \\
\hline 13 & transient & March 2010 to February 2012 & Flat or increase & Above average \\
\hline 14 & transient & March 2012 to November 2012 & \multicolumn{2}{|c|}{ Delineated to match data-collection period } \\
\hline 15 & transient & December 2012 to February 2013 & \multicolumn{2}{|c|}{ Delineated to match data-collection period } \\
\hline 16 & transient & March 2013 to November 2013 & \multicolumn{2}{|c|}{ Delineated to match data-collection period } \\
\hline \multicolumn{5}{|c|}{ Projection periods } \\
\hline & Stress period & Time simulated & \multicolumn{2}{|c|}{ Recharge during stress period } \\
\hline 1 & transient & 11 years & \multicolumn{2}{|c|}{ Same length and recharge as stress period 2} \\
\hline 2 & transient & 4 years & \multicolumn{2}{|c|}{ Same length and recharge as stress period 3} \\
\hline 3 & transient & 11 years & \multicolumn{2}{|c|}{ Same length and recharge as stress period 4} \\
\hline 4 & transient & 3 years & \multicolumn{2}{|c|}{ Same length and recharge as stress period 5} \\
\hline 5 & transient & 4 years & \multicolumn{2}{|c|}{ Same length and recharge as stress period 6} \\
\hline 6 & transient & 2 years & \multicolumn{2}{|c|}{ Same length and recharge as stress period 7} \\
\hline 7 & transient & 4 years & \multicolumn{2}{|c|}{ Same length and recharge as stress period 8} \\
\hline 8 & transient & 6 years & \multicolumn{2}{|c|}{ Same length and recharge as stress period 9} \\
\hline 9 & transient & 4 years & \multicolumn{2}{|c|}{ Same length and recharge as stress period 10} \\
\hline 10 & transient & 6 years & \multicolumn{2}{|c|}{ Same length and recharge as stress period 11} \\
\hline 11 & transient & 5 years & \multicolumn{2}{|c|}{ Same length and recharge as stress period 12} \\
\hline 12 & transient & 2 years & \multicolumn{2}{|c|}{ Same length and recharge as stress period 13} \\
\hline 13 & transient & 938 years & \multicolumn{2}{|c|}{ Same recharge as steady-state long-term average } \\
\hline 14 & transient & 4,000 years & \multicolumn{2}{|c|}{ Same recharge as steady-state long-term average } \\
\hline
\end{tabular}



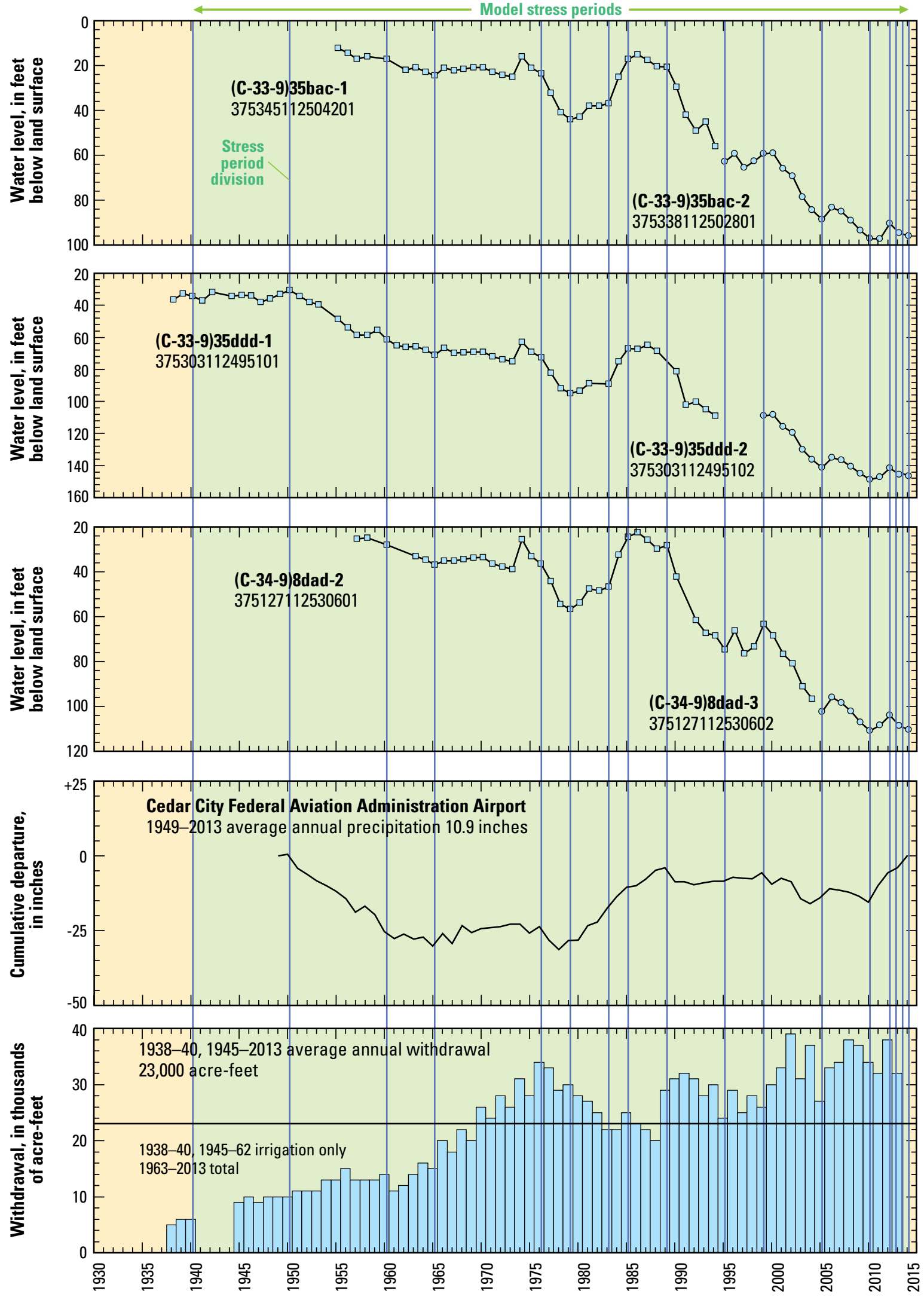

Figure 3. Selected groundwater levels, precipitation, and well withdrawals in Parowan Valley, Utah, and stress periods of the GBCAAS v. 3.0 groundwater model, Great Basin carbonate and alluvial aquifer system study area, 1937 to 2015 (modified from Burden and others, 2016). 

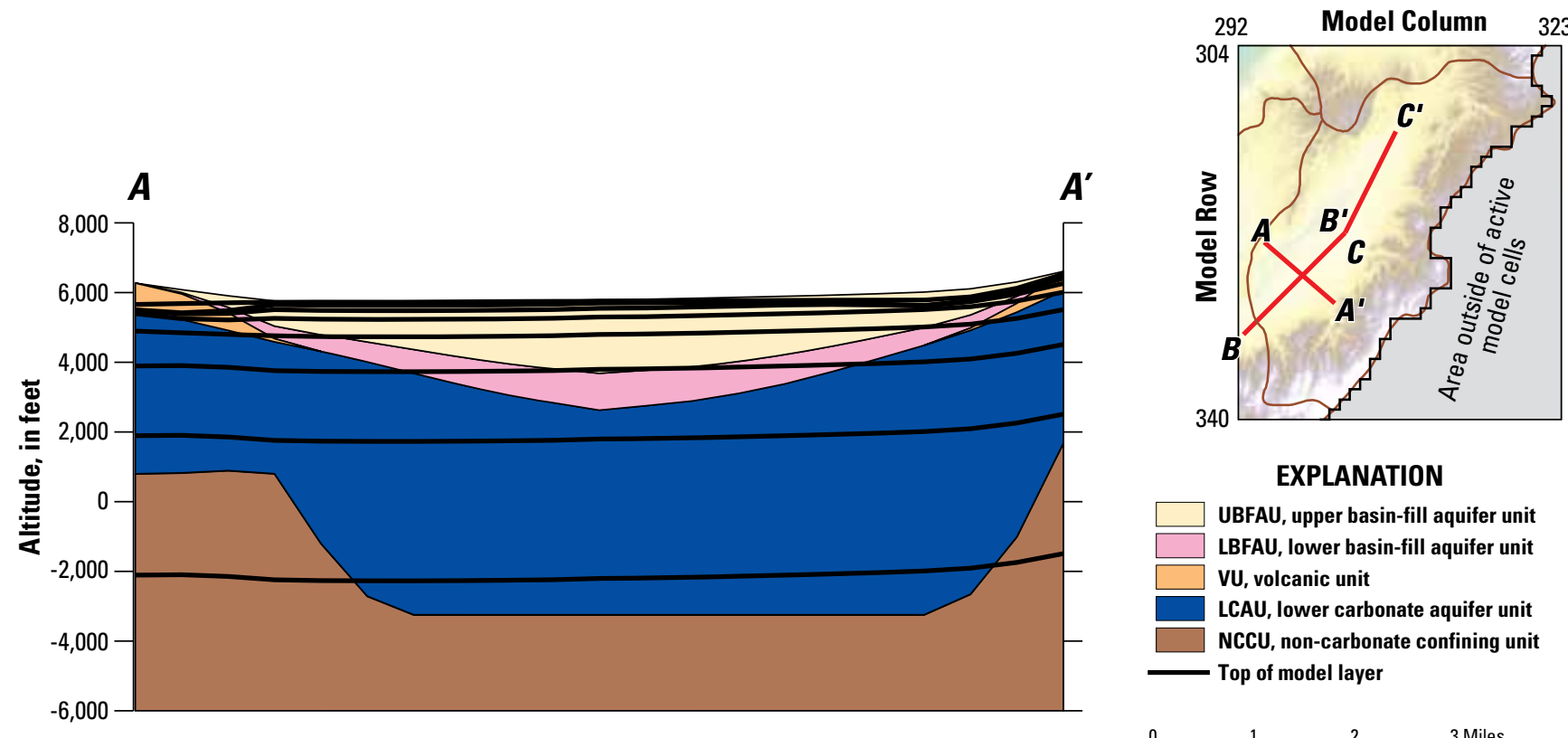

\section{EXPLANATION}

UBFAU, upper basin-fill aquifer unit LBFAU, lower basin-fill aquifer unit VU, volcanic unit

LCAU, lower carbonate aquifer unit NCCU, non-carbonate confining unit Top of model layer
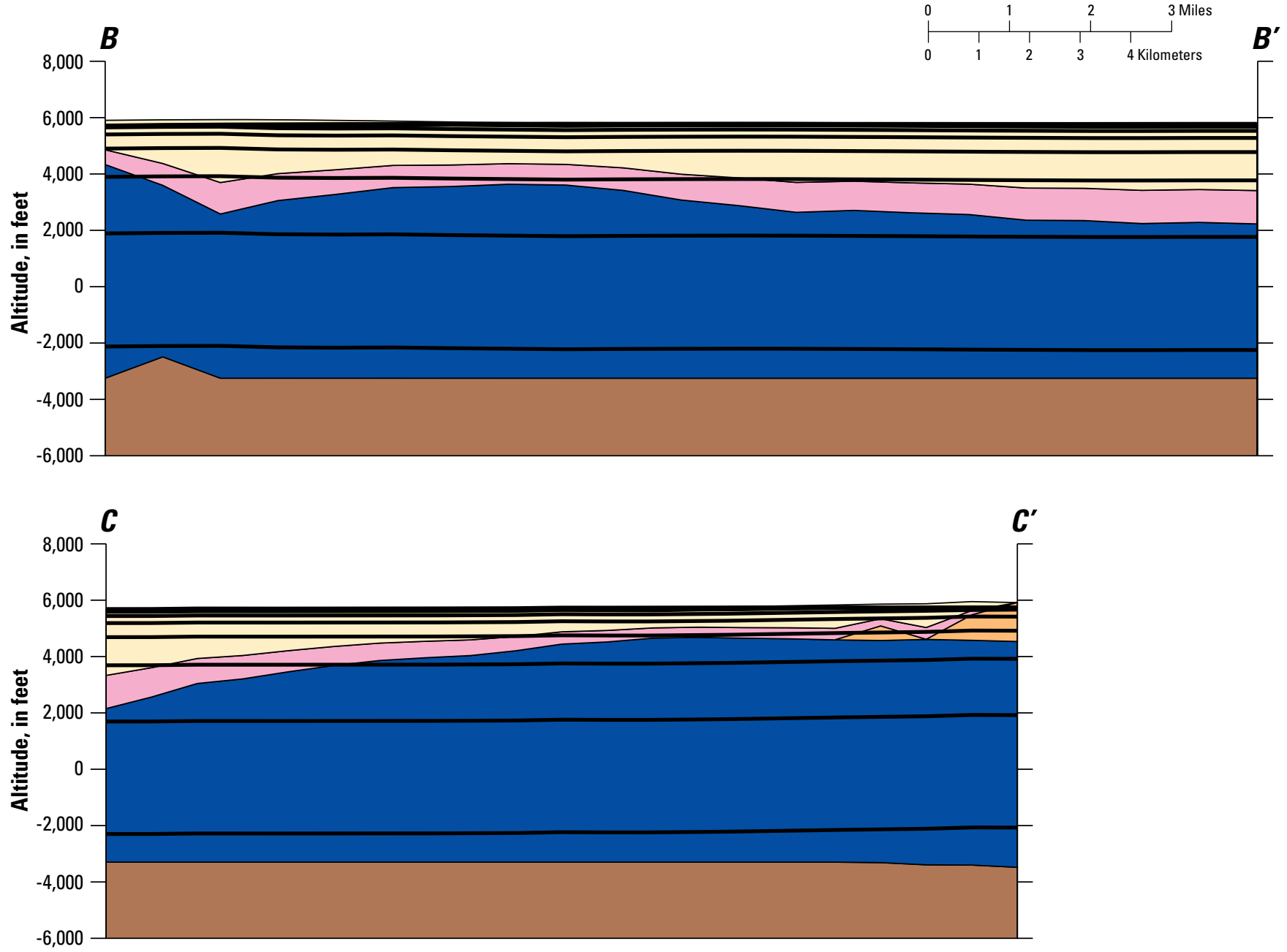

Figure 4. Cross sections showing hydrogeologic units and model layers in the GBCAAS v. 3.0 groundwater model, Parowan Valley, Utah. 
not change during the transient calibration period outside of areas near Parowan Valley. Recharge and pumping in Parowan Valley (HA 281) change in each stress period, as described in the "Boundary Conditions" section of this report.

\section{Projection Stress Periods}

A projection simulation of 14 stress periods demonstrates possible effects of groundwater withdrawals. The stress periods repeat the timing and recharge of the first 12 transient stress periods to provide variation in recharge in Parowan Valley (HA 281) and then add two additional long stress periods (table 1). In Parowan Valley, projection stress periods 1 to 12 (table 1) demonstrate possible reduced annual withdrawals that may prevent continued water-level declines given historic fluctuation in recharge. Projection stress periods 1 to 14 demonstrate the possible length of time for new steady-state conditions to be achieved with proposed withdrawals in Pine Valley (HA 255) and Wah Wah Valley (HA 256).

\section{Boundary Conditions}

The boundaries chosen for the model describe mathematically how the simulated groundwater system interacts with the surrounding hydrologic system. The boundaries define the physical limits of the model and how recharge to and discharge from the groundwater system are simulated. Boundary conditions in GBCAAS v. 3.0 are mostly the same as in previous versions (Brooks and others, 2014; Stolp and others, 2017). This report presents changes in boundary conditions from previous versions to GBCAAS v. 3.0.

\section{Specified-Flow Boundaries}

Specified-flow boundaries allow a specified rate of water into or out of a cell and are used to simulate recharge from precipitation, streams, and irrigation; discharge to wells; and the physical boundary at the lateral edges and bottom of the model. The boundary at the bottom of the model is a no-flow boundary, which is a specified-flow boundary with a flow of zero. The lateral edge of GBCAAS v. 3.0 is also a no-flow boundary everywhere within the model focus area (Brooks and others, 2014, pl. 1).

\section{Recharge from Precipitation, Streams, and Irrigation}

For GBCAAS v. 3.0, changes were made in Parowan Valley (HA 281) to distribute recharge from runoff and baseflow to areas that receive irrigation from streams (fig. 5; Marston, 2017, p. 27). For consistency with the rest of the model, the conceptual steady-state rates and locations of in-place recharge were not changed in Parowan Valley from those used in previous GBCAAS model versions (Brooks, 2014; Stolp and others, 2017). The rates and locations are the same as the estimates from the Basin Characterization Model
(BCM; Flint and others, 2011) that were used in the GBCAAS conceptual groundwater budget (Masbruch and others, 2011). The conceptual rates of in-place recharge and recharge from runoff and irrigation are defined by using multiplier arrays in MODFLOW-LGR. The simulated rate is determined by using model parameters to multiply the conceptual rate. Recharge for each stress period is defined by multiplying the steadystate recharge by factors (fig. 6) determined from monthly recharge in a recent version of BCM (Alan Flint and Lorraine Flint, U.S. Geological Survey, written commun., May 2015). Two parameters are used to simulate recharge from irrigation and runoff to allow the rate to change with the change in irrigation practices from flood irrigation to sprinkler irrigation in the mid-1970s.

The conceptual rates of all recharge for areas outside of Parowan Valley are the same as in GBCAAS v. 2.0. Recharge parameters are used to multiply these conceptual rates and to apply the rates to specific model zones (table 2-2); the zones and parameter values were changed throughout the model focus area as part of recalibration. The simulated recharge (fig. 7) is determined by multiplying the conceptual rates by value of the recharge parameter for each zone. Recharge zones can be determined from data supplied in the model files (Brooks, 2017).

In a few locations, parameters and zones were changed near, but outside, the model focus area, but are not shown in this report. They were adjusted to minimize the effects of changes within the model focus area on simulated water levels and discharge rates outside of the model focus area. For example, reducing simulated recharge in Snake Valley (HA 254) may have affected water levels in surrounding areas outside of the model focus area. Recharge in those areas was increased, if needed, to simulate water levels and discharge similar to those simulated in previous versions. Changes can be determined from the model files (Brooks, 2017) and previous model archives (Brooks and others, 2014; Stolp and others, 2017).

\section{Wells}

Withdrawals from municipal and irrigation wells in Parowan Valley (HA 281) and two wells in Cedar City Valley (HA 282) are simulated by using the Well Package (Harbaugh, 2005, p. 6-1 to 6-2). The Well Package simulates a specified stress at the row, column, and layer of each well (fig. 8). The discharge from each layer for each well was assumed to be proportional to the length of the screened interval in each layer. No wells are simulated in layers deeper than layer 5 .

Withdrawal from each irrigation well was estimated in 2013 (Marston, 2017, p. 28-30), and total annual irrigation withdrawals have been reported by the USGS since 1938 (fig. 3; Burden and others, 2016, fig. 27). Pumping rates for individual wells were not available before 1997, and the complexities of individual well withdrawal for each year after that were not necessary for the scope and objectives of this project. Pumping in the northern part of the valley (fig. 8) did not start until 1973, and for model input was assumed to increase linearly from a total of 1,800 acre-feet per year (acre-ft/yr) in 

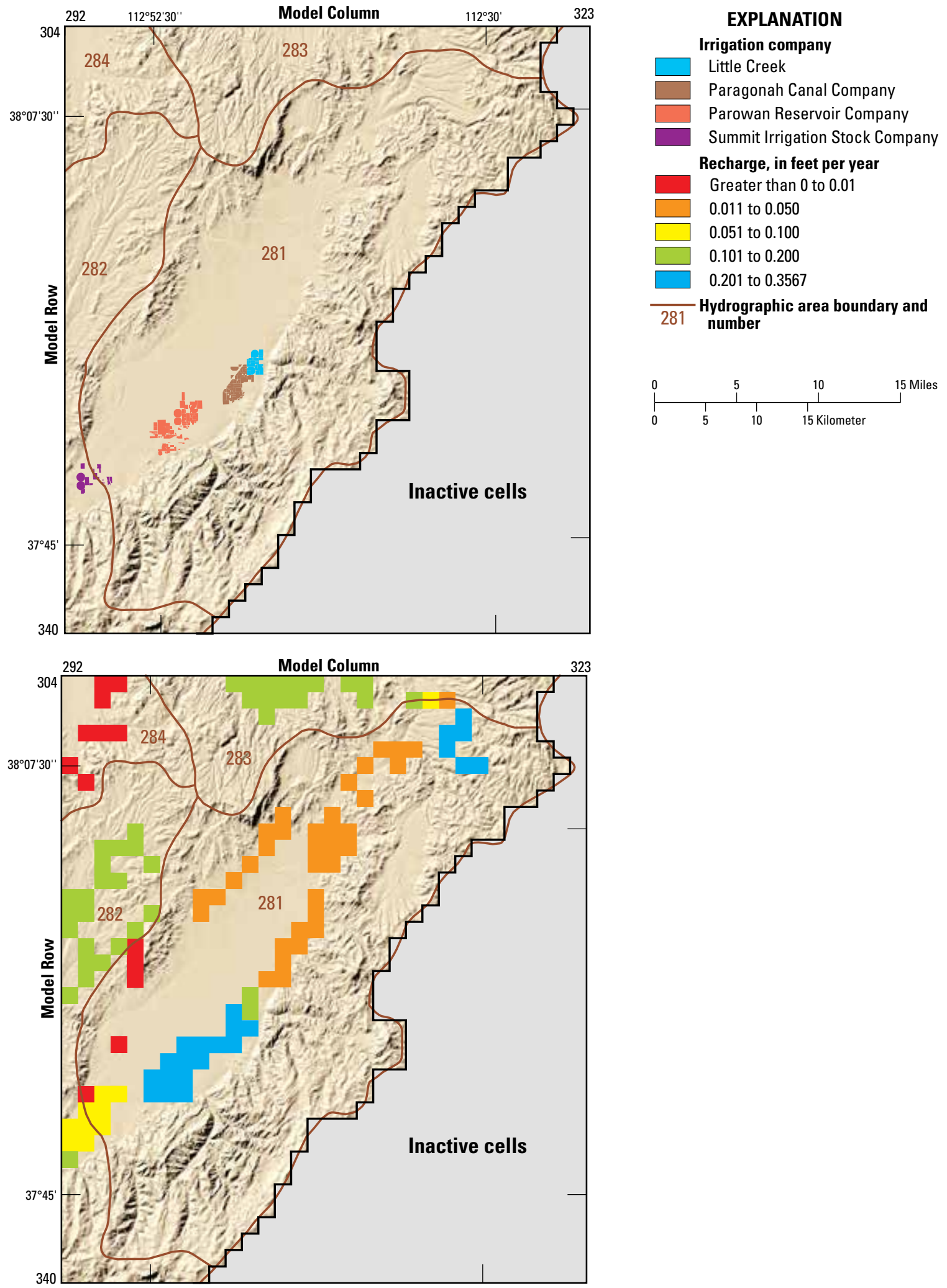

Figure 5. Source of irrigation by surface water and rate of conceptual recharge from runoff and irrigation by surface water in Parowan Valley, Utah. 
1973 to 7,200 acre-ft/yr (the total of individual well estimates) in 2013 (fig. 9). The total withdrawal in the southern part of the valley for each stress period was assumed to equal the total reported withdrawal minus the estimated withdrawal in the northern part of the valley and, therefore, varies more than the withdrawal assumed in the northern part of the valley (fig. 9). The rate for each well during each stress period was assumed to be the same proportion of the total as was estimated during 2013 (Marston, 2017, p. 28-30). Municipal well withdrawals are available from the Utah Division of Water Rights (https://www.waterrights.utah.gov/wateruse/WaterUseList.asp, accessed on Jan. 19, 2017), and values for years in which data were missing were interpolated as part of this project. Stress period 15 is from November 2012 to February 2013 and has no simulated pumping. Because withdrawal estimates were not exact, parameters were used to adjust pumping on a spatial and temporal basis during model calibration.

\section{Head-Dependent Boundaries}

Most discharge from the groundwater system in the study area is to ETg, springs, and rivers; these discharge processes are simulated using head-dependent flow boundaries. In cells with a head-dependent boundary, groundwater is simulated as discharging from a cell if the simulated head is above the specified boundary altitude. The rate of discharge is determined by the difference in simulated water level and boundary altitude and by the boundary conductance. Because multiple headdependent boundaries in a single model cell can cause numerical instability, only one boundary is simulated in each cell that has a head-dependent boundary. These adjustments were only required in a few locations and likely had negligible effect on this regional model. Generally, the order of priority for assigning discharge to a specific observation was as follows: individual springs, rivers, and ETg. This allowed the model boundary conditions to simulate the most specific discharge estimates among the model observations. Selected small springs were included with area springs or ETg (table 1-1).

\section{Evapotranspiration}

ETg was changed in Parowan Valley (HA 281), Sevier Desert (HA 287), Tule Valley (HA 257), and Snake Valley (HA 254) to represent more recent and more detailed data than used in previous versions and to use the Evapotranspiration Package (Harbaugh, 2005, p. 6-16) instead of the Drain Package (table 2; fig. 10). The areas and rates of ETg were changed from previous versions in Tule Valley (HA 257) and Sevier Desert (HA 287) on the basis of recent data (Philip Gardner, U.S. Geological Survey, written commun., September 25, 2014). The areas and rates of ETg in Parowan Valley (HA 281) were changed from previous versions on the basis of reexamination of Thomas and Taylor (1946, p. 168-172). Although the estimates of areas and rates of ETg in Pavant Valley (HA 286) and Leamington Canyon (HA 285) were not changed, ETg was changed to the Evapotranspiration Package in these areas because the Drain Package used the same parameter as Sevier Desert in previous model versions.

Required information to simulate ETg by using the Evapotranspiration Package is the estimated rate of ETg (table 2 ), the altitude of the land surface, and the extinction depth. The estimated rate is defined by using a multiplier array. Parameters are assigned to specific areas of ETg using zones and are multipliers of the estimated rate. The altitude of the land surface is simulated as the lowest altitude in the model cell as determined from the NED (U.S. Geological Survey EROS Data Center, 1999). The previously simulated extinction depth of $40 \mathrm{ft}$ (Brooks and others, 2014, p. 27) was used everywhere except Parowan Valley (HA 281), where $10 \mathrm{ft}$ was used. Most ETg in Parowan Valley is through saltgrass

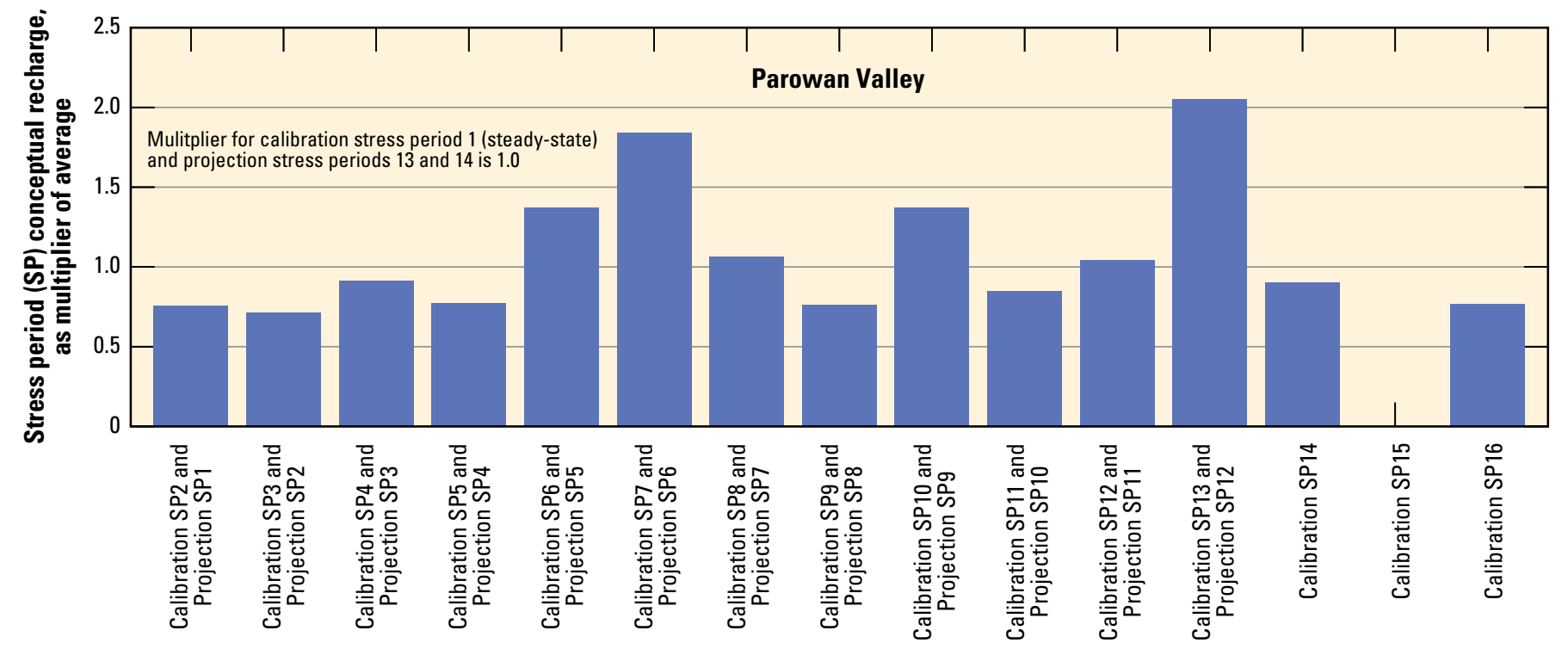

Figure 6. Multiplier for conceptual recharge in Parowan Valley, Utah, for each transient stress period of the GBCAAS v. 3.0 groundwater model. 


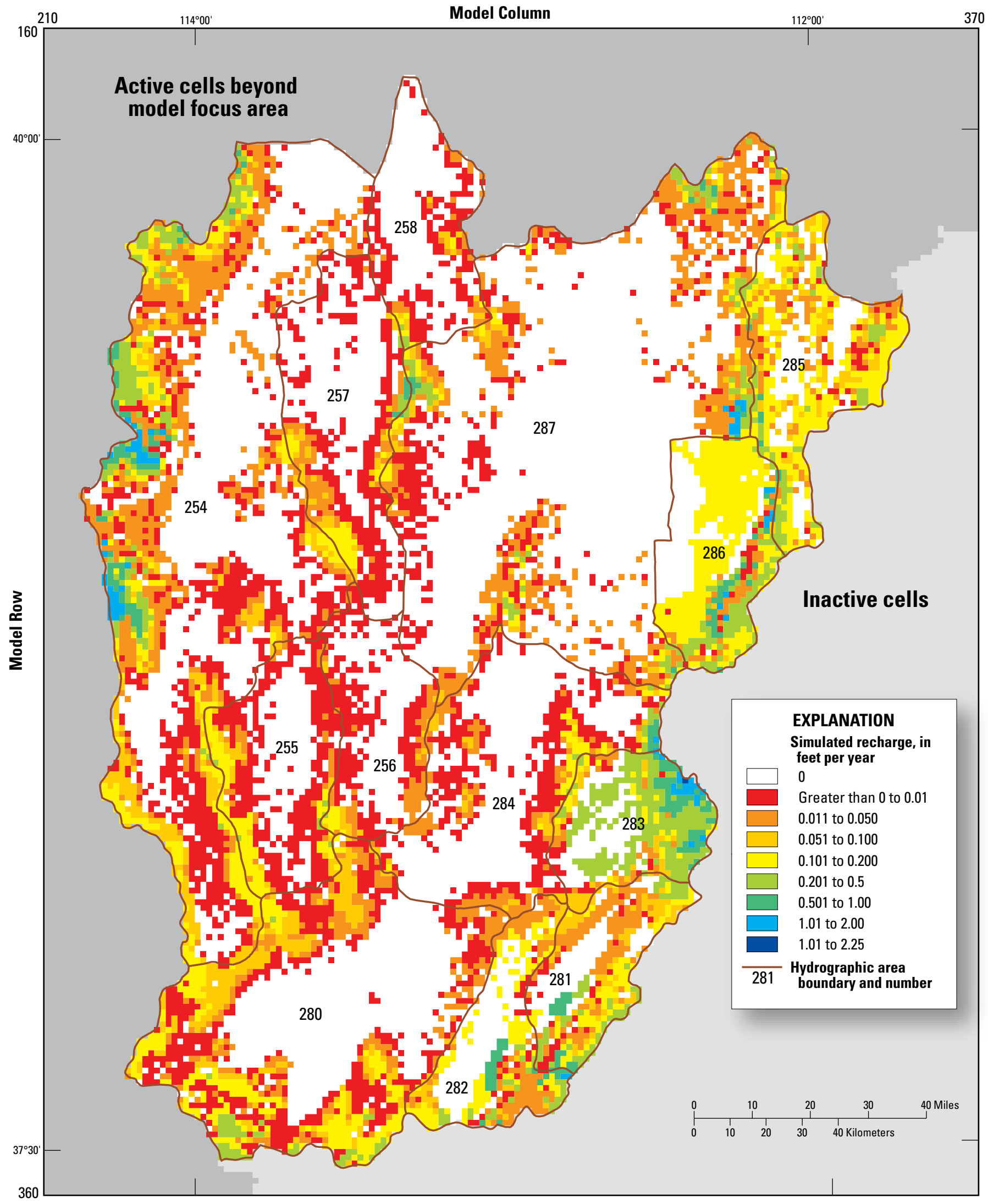

Figure 7. Distribution of simulated recharge for stress period 1 (steady-state) of the GBCAAS v. 3.0 groundwater model, model focus area, Utah and Nevada. 


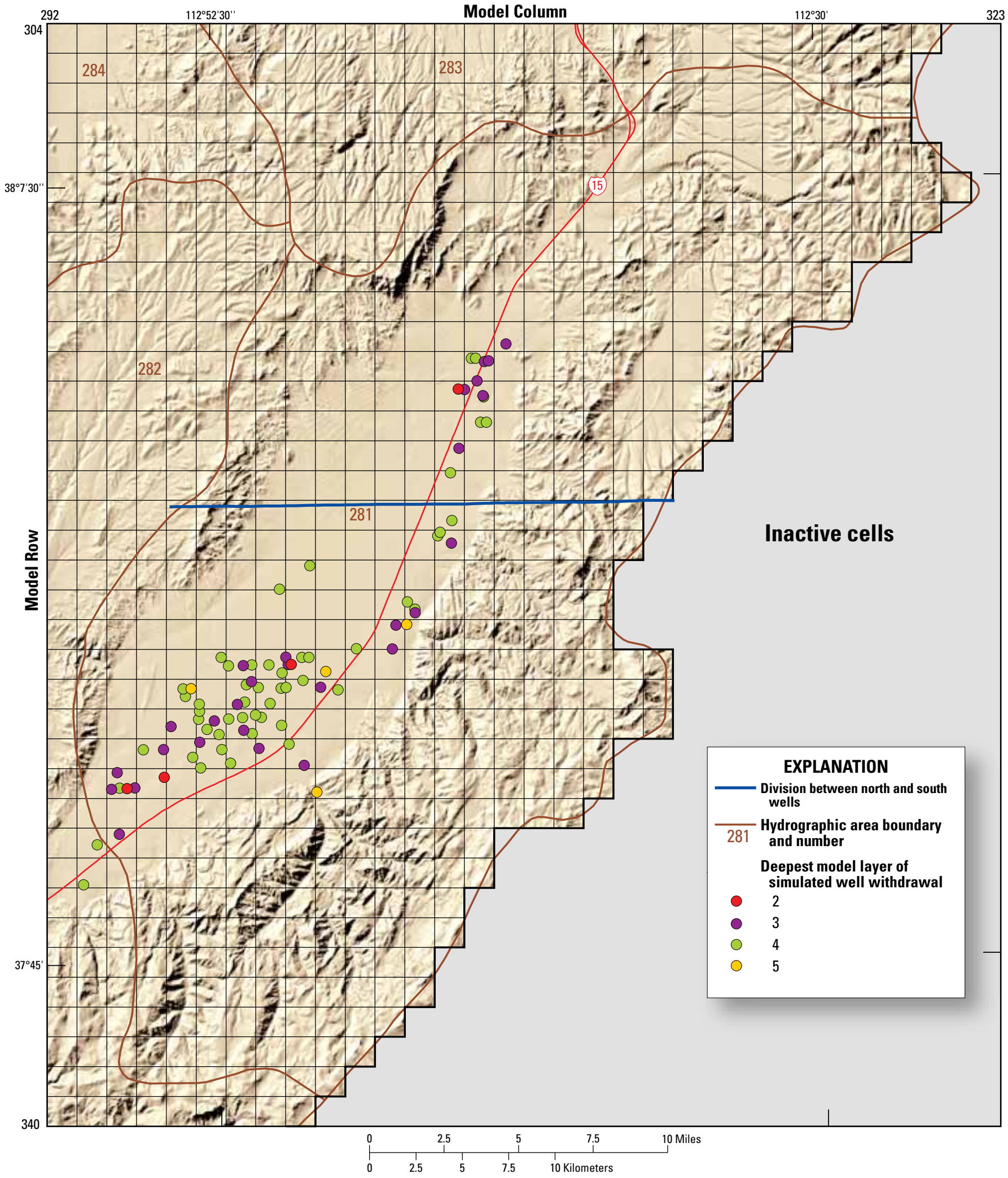

Figure 8. Location and deepest model layer of simulated well withdrawals in and near Parowan Valley, Utah, in the GBCAAS v. 3.0 groundwater model. 

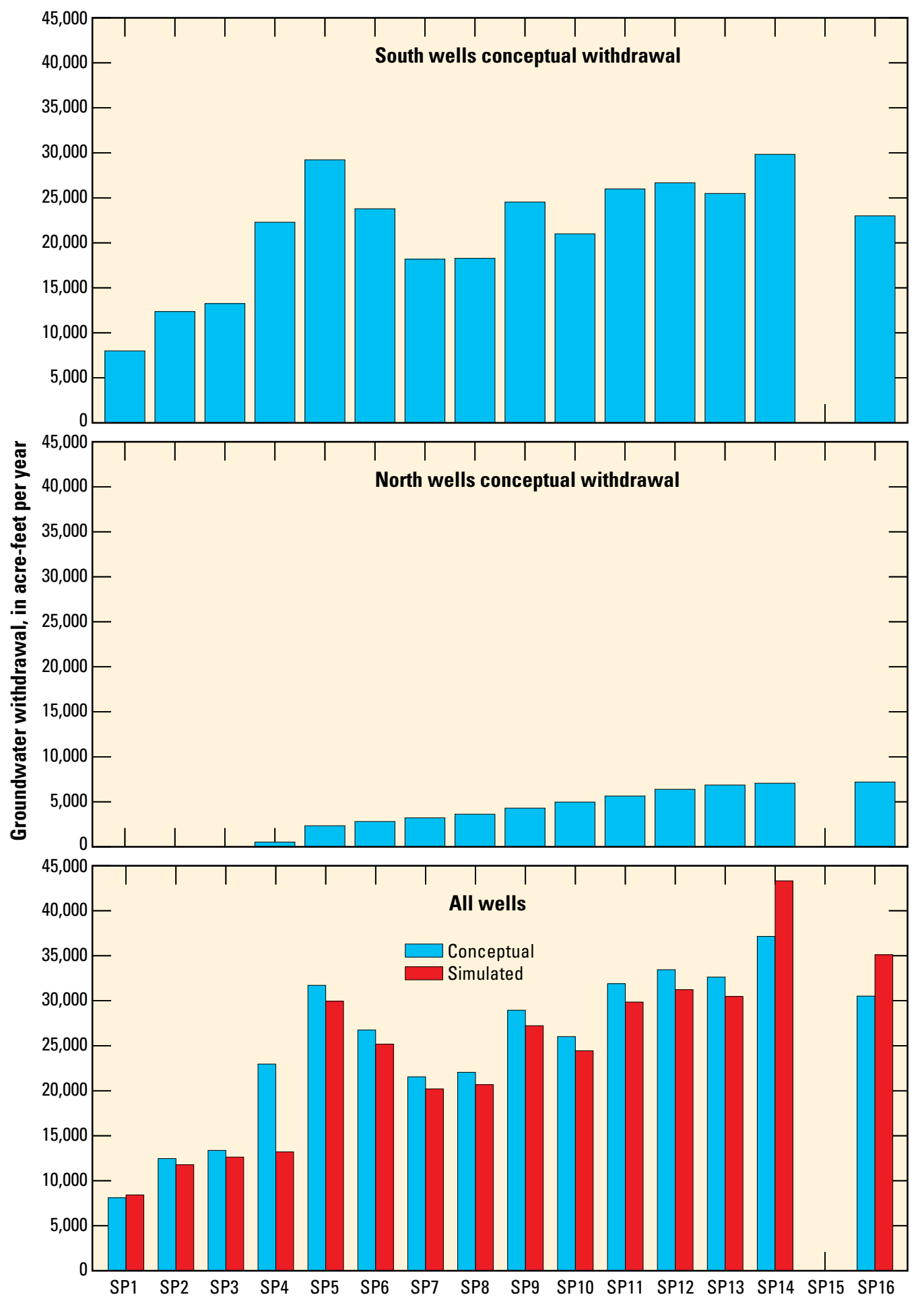

Figure 9. Conceptual and simulated well withdrawals in and near Parowan Valley, Utah, for each calibration stress period of the GBCAAS v. 3.0 groundwater model, 194 to 2015. 


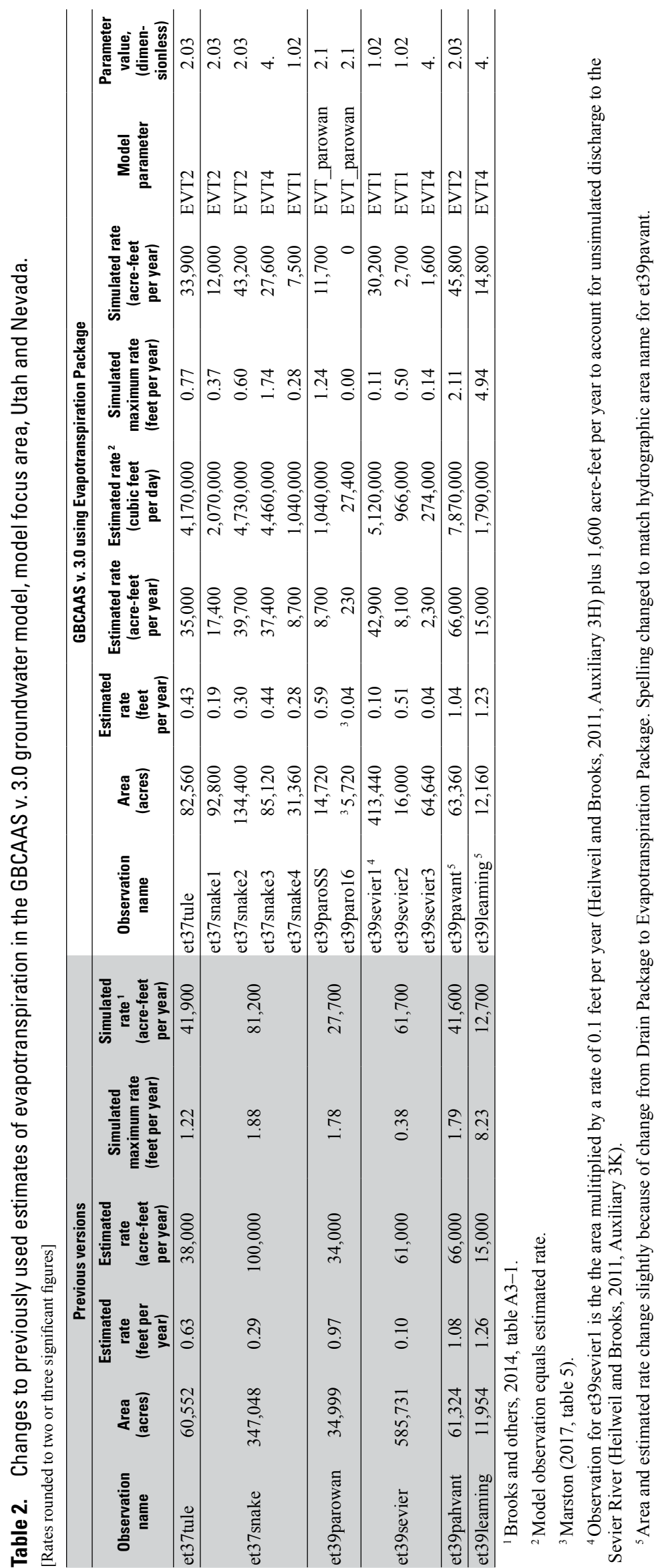

(Thomas and Taylor, 1946, p. 168-172). Saltgrass is a shallow-rooted plant generally found where the depth to water is less than $8 \mathrm{ft}$, but has been observed growing where the depth to water is about $12 \mathrm{ft}$ (Robinson, 1958, p. 56).

\section{Springs}

Discharge to springs is simulated from multiple layers by using the Drain Package (Harbaugh, 2005, p. 6-12). Two springs and a spring discharge area were added to the model in Parowan Valley (HA 281; fig. 11; table 1-2) because more detailed data were used than in previous versions. Three springs (Miller Spring, Clay Spring, and Dearden Spring Group) were added to the model in Snake Valley (HA 254; fig. 11; table 1-2) because data were available (Masbruch and others, 2014, table 12) that previously were not. Large springs typically required drain boundaries in multiple model layers to match observed spring discharge. All springs are simulated in layer 1, and deeper layers were added as needed to achieve a closer match to observed spring discharge. The conductance factor for all point springs is onetenth of the model cell area. The conductance factor for area springs is the area of the spring in each cell. During calibration, the number of layers and the simulated altitude of selected springs were adjusted from previous versions (table 1-3).

\section{Rivers}

Discharge to rivers (fig. 11) is simulated by using the River Package (Harbaugh, 2005, p. 6-6 to 6-12). The hydraulic conductivity of the riverbed along selected river segments in HAs 285 and 287 was increased from the value in previous versions (table 1-4) to increase simulated discharge to the river and reduce simulated water levels near the segments. This caused simulated equivalents of water levels and discharge to the river to more closely match observations. No other changes from previous versions were made to the River Package. 


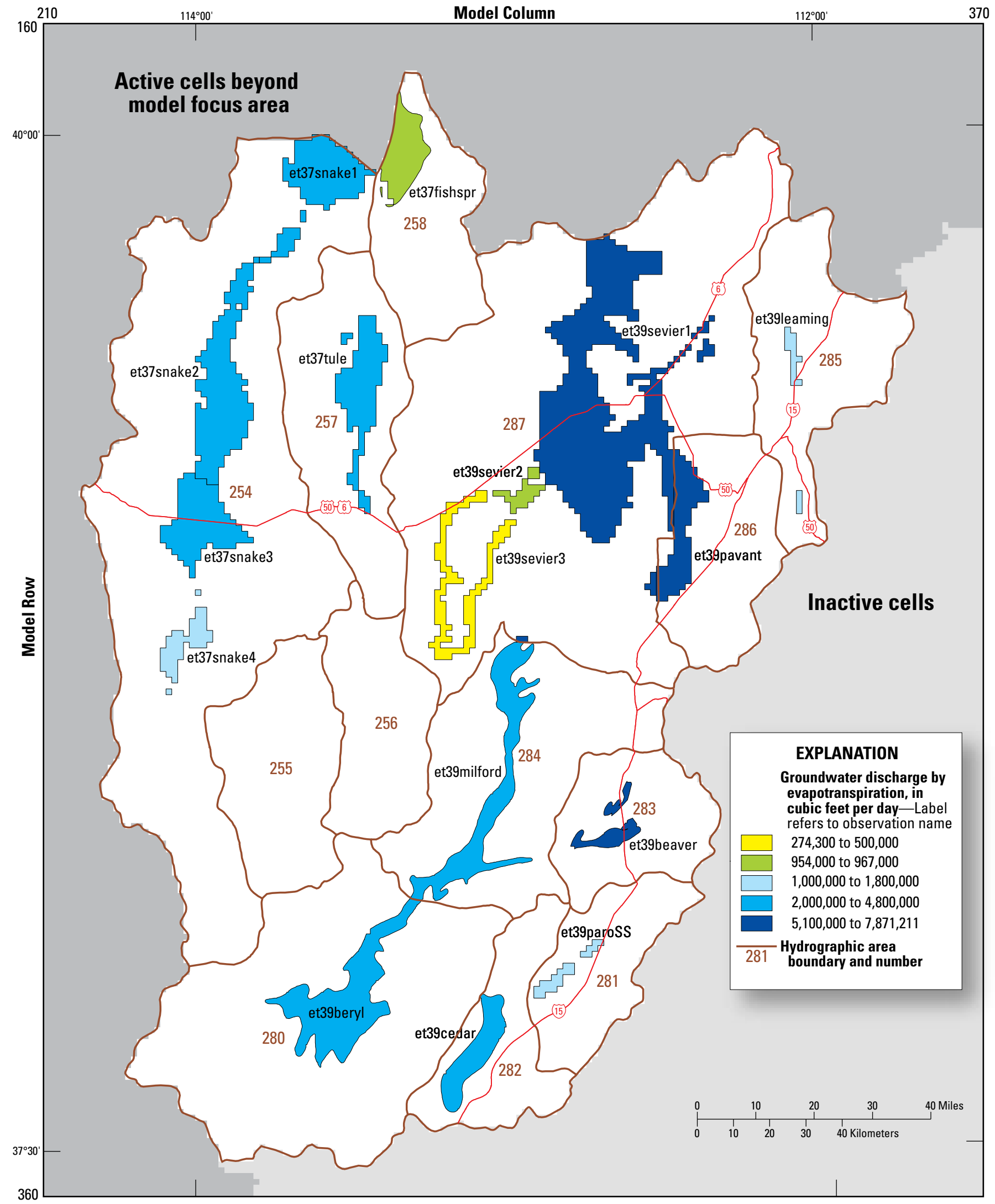

Figure 10. Location and observed discharge by evapotranspiration in the GBCAAS v. 3.0 groundwater model, model focus area, Utah and Nevada. 


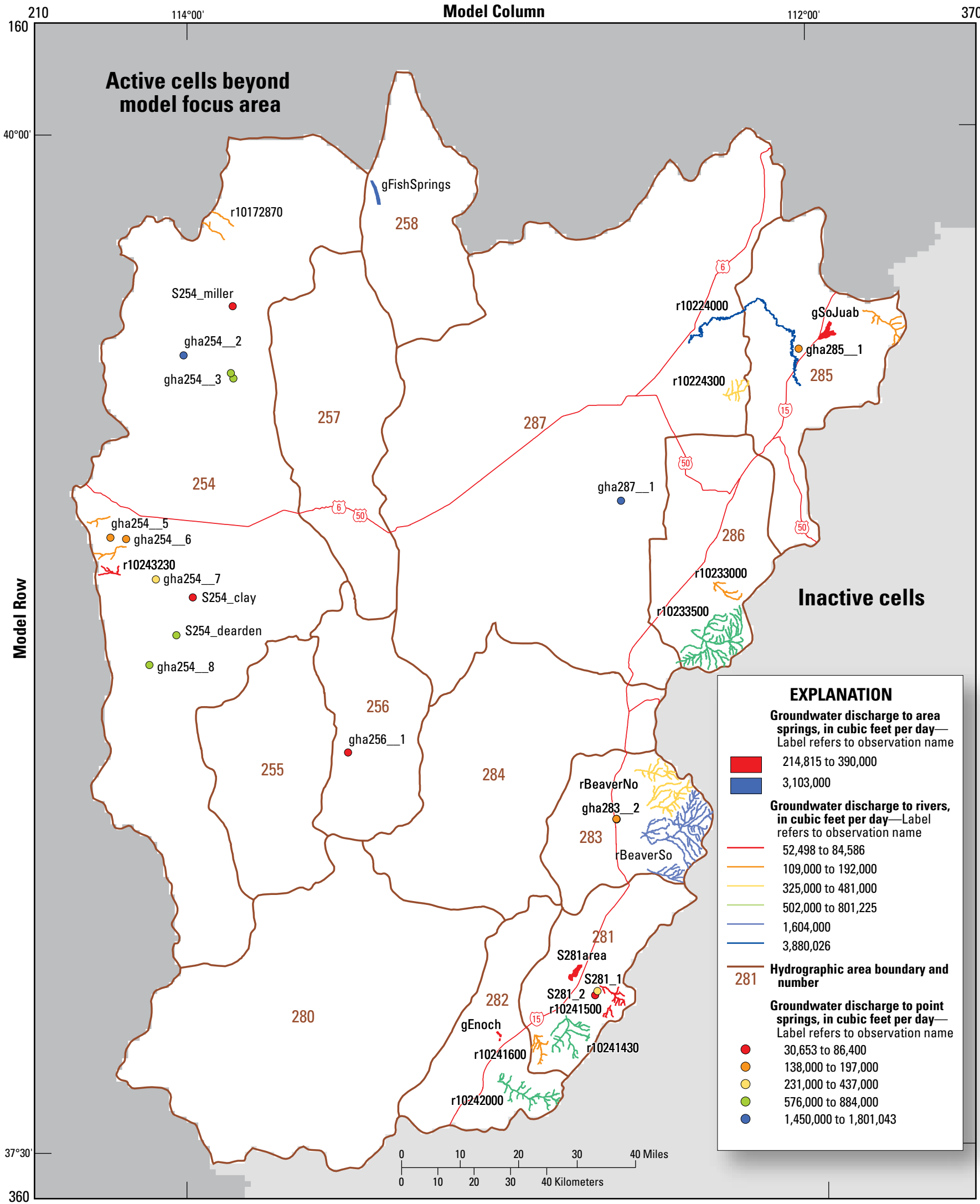

Figure 11. Location and observed discharge to springs and rivers in the GBCAAS v. 3.0 groundwater model, model focus area, Utah and Nevada. 


\section{Hydraulic Properties}

The nine hydrogeologic units (HGUs) described in Sweetkind and others (2011a) were the basis for assigning horizontal hydraulic conductivity and vertical anisotropy to the model layers. The HGUs are simulated using the Hydrogeologic-Unit Flow (HUF) Package (Anderman and Hill, 2000, 2003) of MODFLOW-2005, which can represent the complexities of the geology. Hydrogeologic structures that act as barriers to groundwater water flow were simulated using the HorizontalFlow Barrier (HFB) Package (Harbaugh, 2005, p. 5-21 to 5-22).

\section{Hydrogeologic Units}

The HUF Package takes the tops and thicknesses of each HGU as input and allows the hydraulic conductivity and vertical anisotropy of the HGUs to be defined through zones and parameters. The HUF Package determines the hydrogeologic units that apply to each model cell (Anderman and Hill, 2000, fig. 1C). Some model cells are filled by a single HGU, whereas other model cells contain multiple HGUs. The HUF Package calculates the effective hydraulic conductivity in both the vertical and horizontal direction for each cell (Anderman and Hill, 2000, p. 7). Zones and parameter values in most of the HGUs in the study area were changed from previous versions as part of recalibration. Thickness and extent of each HGU in the model focus area was not changed from previous versions (Brooks and others, 2014). Thickness and extent of each HGU can be visualized using the geographic information system (GIS) data provided in Brooks (2017).

\section{Structures Simulated as Barriers}

Faults can create barriers to flow by juxtaposition of lowpermeability materials and relatively high-permeability materials, and by low-permeability material (fault gouge) in the fault zone itself, which forms a barrier to flow across the fault (Caine and others, 1996). Juxtaposition is represented in the flow model by the geometry of the hydrogeologic framework (Cederberg and others, 2011). Faults, or portions of faults, that appear to create an additional barrier to flow are simulated using the Horizontal-Flow Barrier (HFB) Package (Harbaugh, 2005 , p. 5-21 to 5-22) of MODFLOW-2005. These flow barriers (fig. 12) were located along cell boundaries to approximate the location of selected major faults (Sweetkind and others, 2011a, fig. B-8). The HFBs are simulated in all model layers in some locations and in only lower model layers where less of a barrier is needed or where having an HFB for the full depth caused simulated water levels to be above land-surface altitude on the upgradient side of the HFB. The model input required for the HFB Package is the hydraulic characteristic of the barrier, which is the hydraulic conductivity of the barrier divided by the width of the barrier. It was assumed in this model that the width is $1 \mathrm{ft}$. The hydraulic conductivity is defined using parameters. Changes were made to HFBs in the study area as part of recalibration.

\section{Observations Used in Model Calibration}

Model observations are measured or estimated values that are compared to simulated equivalents as part of model calibration, sensitivity analyses, and parameter estimation. Model observations used in GBCAAS v. 3.0 are groundwater levels at wells and discharge locations, and discharge to springs, ETg, rivers, and lakes (table 3). All observations used in the model outside of Parowan Valley (HA 281) are considered representative of steady-state conditions. For each observation, uncertainty was estimated as explained in the appropriate section. Uncertainties were expressed as standard deviation, variance, or coefficient of variation and were converted to variance, which UCODE_2014 (Poeter and others, 2014) uses to define weights as the inverse of the variance (Poeter and others, 2008, p. 19). Weights are applied to the observations for calibration statistics, sensitivity analyses, and parameter estimation. The term "simulated equivalent" is used to denote the simulated value compared to the observation.

\section{Water Levels in Wells}

Water levels used for observations in GBCAAS v. 3.0 include most water-level observations used in previous versions (table 1-5; Brooks and others, 2014, table A2-1; Stolp and others, 2017, table A3-1). Additional water levels used in GBCAAS v. 3.0 that were modified from GBCAAS v. 2.0 or were not used in GBCAAS v. 2.0 were from Masbruch and others (2014), from the USGS National Water Information System (NWIS), or provided by CH2M (table 1-5). The steady-state calibration target at each well was the average water level over the time period for which water-level measurements in the well were used. Decadal and seasonal fluctuations were treated as noise in the observations and were accounted for through an analysis of observation errors. Wells were used as observations only if their land-surface altitude and depth were known. The open intervals of wells were used to determine the model layers associated with the observations. For wells open to more than one model layer, simulated heads are a weighted average calculated by the MODFLOW-2005 Head Observation Package (HOB) on the basis of the length of opening in each layer (Harbaugh and Hill, 2009, p. 5). The layer definition for observations was not redefined when layering was adjusted; the effect on simulated water level was considered unimportant compared to other factors. Most of the wells have open intervals and completion depths in the upper model layers (figs. 13 and 14). Uncertainty associated with water levels in wells involves multiple sources of error (table 1-5), as explained in Brooks and others (2014) and San Juan and others (2010). 


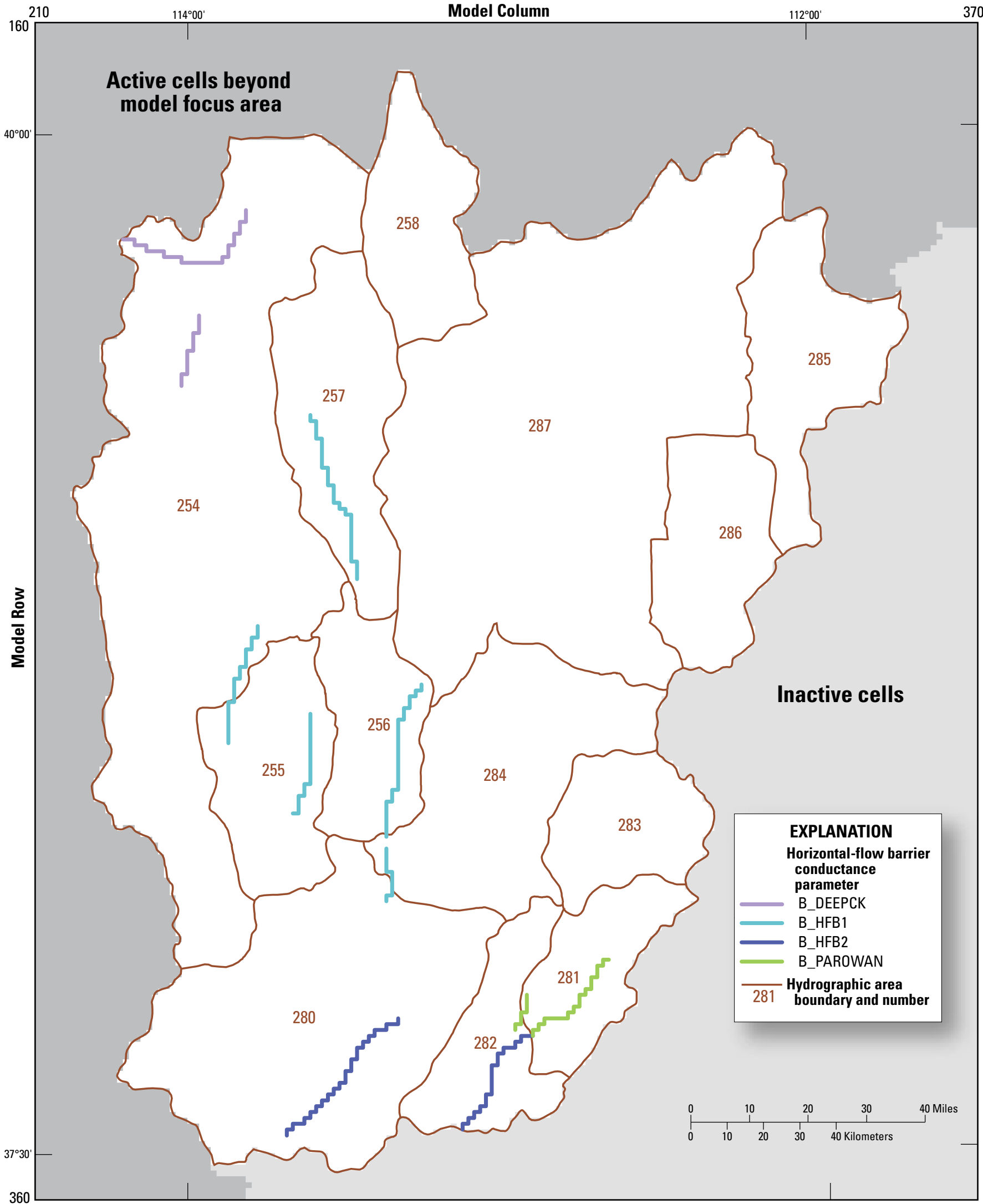

Figure 12. Location and conductance parameter of horizontal-flow barriers simulated using the Horizontal-Flow Barrier Package in the GBCAAS v. 3.0 groundwater model, model focus area, Utah and Nevada. 
Table 3. Summary statistics of observations in the GBCAAS v. 3.0 groundwater model, model focus area, Utah and Nevada.

[All water-level observations in feet. All discharge observations in cubic feet per day. Weights of transient water-level observations were decreased for calibration and weights of 53 discharge observations were increased for calibration, and average weighted standard deviation or coefficient of variation is value used in model regression and fit statistics. Abbreviation: - , not applicable]

\begin{tabular}{|c|c|c|c|c|c|c|c|}
\hline Type of observation & $\begin{array}{c}\text { Number of } \\
\text { observations }\end{array}$ & $\underset{\text { observation }}{\text { Minimum }}$ & $\underset{\text { observation }}{\text { Maximum }}$ & $\begin{array}{c}\text { Average } \\
\text { observation }\end{array}$ & $\begin{array}{l}\text { Average } \\
\text { standard } \\
\text { deviation }\end{array}$ & $\begin{array}{c}\text { Average } \\
\text { coefficient of } \\
\text { variation }\end{array}$ & $\begin{array}{c}\text { Average weighted } \\
\text { standard deviation } \\
\text { or coefficient of } \\
\text { variation }\end{array}$ \\
\hline \multicolumn{8}{|c|}{ Water levels } \\
\hline Spring and river altitudes & 29 & 4,821 & 8,632 & 6,059 & 22.3 & - & 22.3 \\
\hline Total or weighted average & 400 & 4,310 & 9,645 & 5,215 & 13.4 & - & 13.4 \\
\hline Water-level changes in transient periods & 293 & -83 & 26 & -23 & 0.32 & - & 2.61 \\
\hline \multicolumn{8}{|c|}{ Discharge $^{1}$} \\
\hline Spring discharge ${ }^{2}$ & 21 & 0 & $-3,103,000$ & $-539,702$ & - & 0.25 & 0.11 \\
\hline $\begin{array}{l}\text { Evapotranspiration simulated using the } \\
\text { Drain Package }\end{array}$ & 5 & $-954,086$ & $-5,927,261$ & $-3,308,294$ & - & 0.3 & 0.13 \\
\hline $\begin{array}{l}\text { Evapotranspiration simulated using the } \\
\text { Evapotranspiration Package }\end{array}$ & 12 & $-27,430$ & $-7,871,211$ & $-2,796,724$ & - & 0.3 & 0.13 \\
\hline
\end{tabular}

${ }^{1}$ Discharge is considered negative in MODFLOW. A larger discharge, therefore, is a more negative number.

${ }^{2}$ The minimum observation is for Parowan Valley in model stress period 16

${ }^{3}$ Evapotranspiration simulated using the Evapotranspiration Package is negative in MODFLOW. MODFLOW, however, does not provide observations for evpotranspiration. The observation, therefore, is derived from ZONEBUDGET output files, in which evapotranspiration is a positive number, but is reported here as a negative number.

${ }^{4}$ Sixteen river observations are used in MODFLOW for budget accounting, but the amount of groundwater discharge to one of the rivers is not known, and it is not used as a UCODE observation for calibration.

\section{Water Levels at Discharge Locations}

Water levels at selected springs were used as observations because if the simulated discharge to a head-dependent boundary is zero, the sensitivity of the discharge observation to all parameters is also zero. In that case, regression does not change parameters to cause discharge. Water levels at these locations, however, are sensitive to model parameters; if the simulated level is below the observed level, regression may change parameters to cause increased water levels and, possibly, simulated discharge. Water levels at springs were also used as observations where the spring altitude was lowered in the Drain Package to allow discharge to be simulated. The altitude used for water-level observations at springs was the spring altitude reported in NWIS (Mathey, 1998), or $10 \mathrm{ft}$ below the altitude determined from NED of land surface at the center of the grid cell or the spring point, whichever was lower. For selected rivers, two points were used as water-level observations, one representing river altitude at a point midway between the gage and the upstream end of the river (the same location where discharge is assumed to start occurring) and one representing the river altitude near the gage. Because the location of discharge along the rivers is not known, these levels generally were not used as observations if the model was simulating at least 50 percent of the observed discharge to the river. The variance assigned to the altitude of discharge points was $1,000 \mathrm{ft}^{2}$. This variance is similar to variances in water levels at wells (table 1-5).

\section{Groundwater Discharge and Uncertainty}

Groundwater discharge observations in GBCAAS v. 3.0 include discharge to springs, ETg, rivers, and lakes. In general, discharge data have larger uncertainty than water-level data, largely because of measurement error and because of seasonal or annual changes that are not defined by what are often only one-time measurements or estimates.

Discharge observations and uncertainty for springs added to GBCAAS v. 3.0 were obtained from Masbruch and others (2014) for Snake Valley and from Marston (2017) and Thomas and Taylor (1946, p. 170-172) for Parowan Valley (table 1-2). Spring observations that were used in previous versions were not changed in GBCAAS v. 3.0.

Discharge observations in the areas where ETg is simulated by using the Evapotranspiration Package (table 2) were developed from data described by Masbruch and others (2014) for Snake Valley (HA 254), Philip Gardner (U.S. Geological Survey, written commun., September 25, 2014) for Tule Valley (HA 257) and the southern part of Sevier Desert (HA 287), and Thomas and Taylor (1946, p. 168-172) for Parowan Valley 


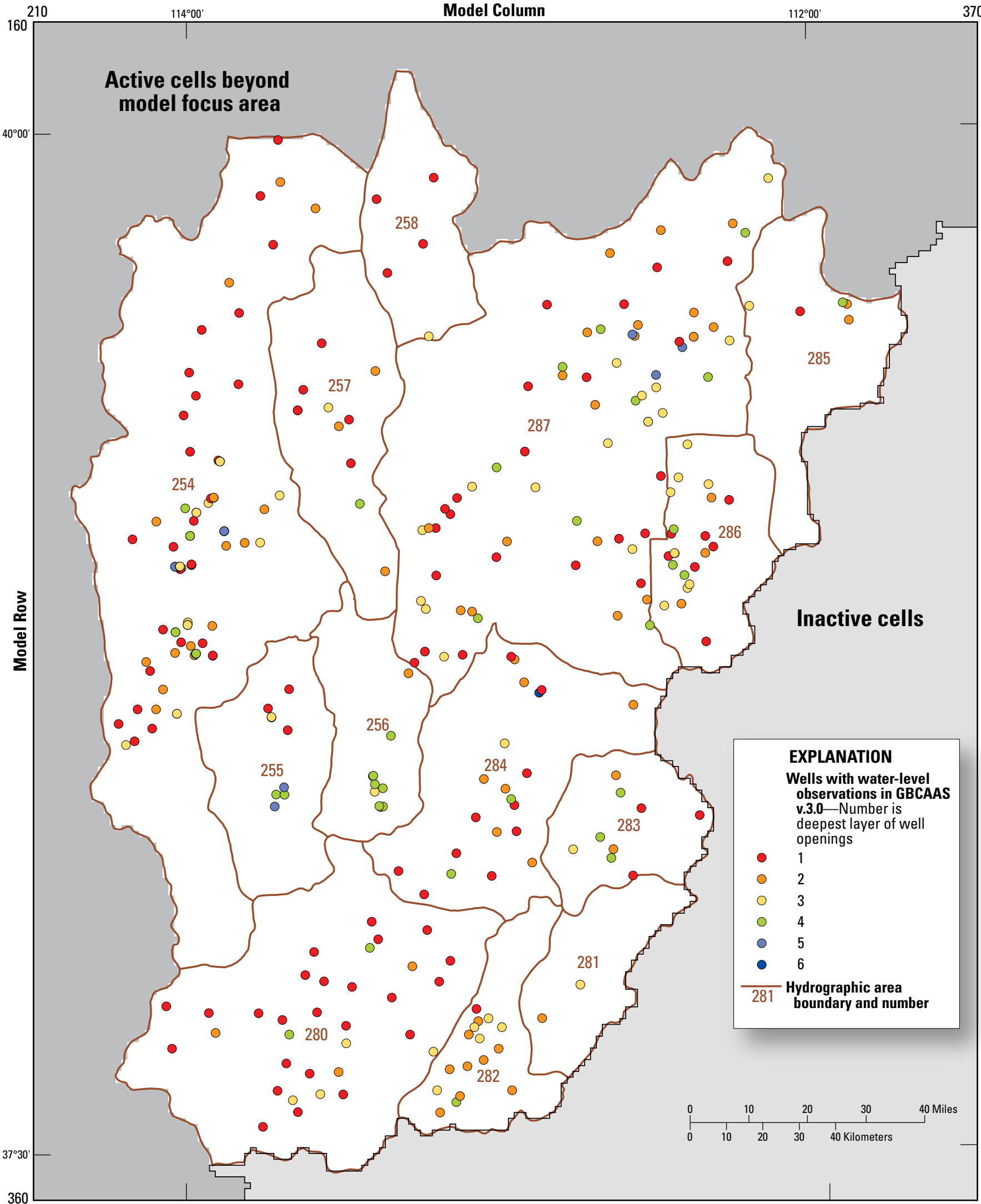

Figure 13. Model-layer distribution of steady-state water-level observations at wells in the GBCAAS v. 3.0 groundwater model, model focus area, Utah and Nevada. 


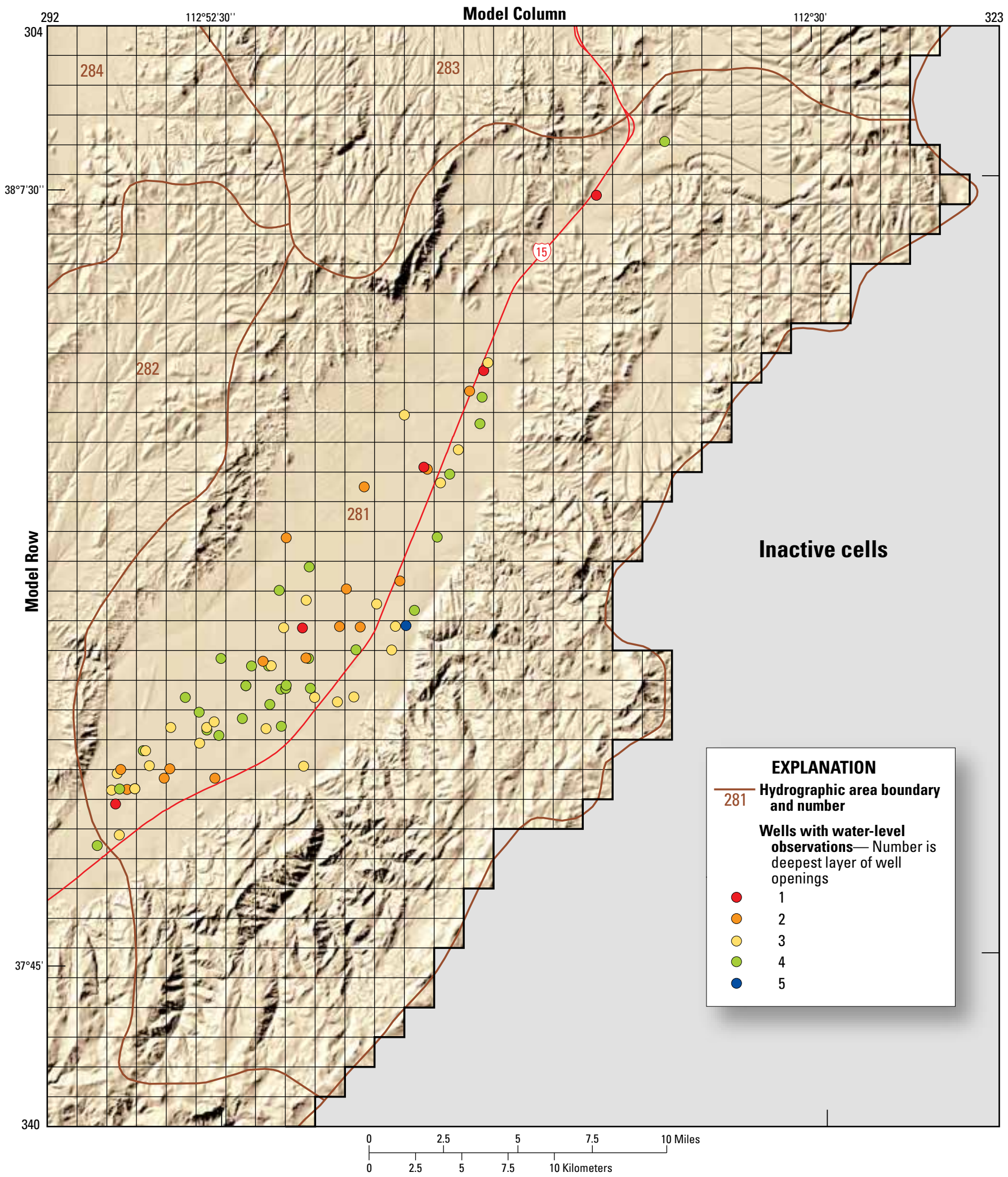

Figure 14. Model-layer distribution of transient water-level observations at wells in the GBCAAS v. 3.0 groundwater model, Parowan Valley, Utah. 
(HA 281). In previous model versions, the total ETg in Sevier Desert was used as one model observation. The recent collection of data around Sevier Lake (observations et39sevier2 and et39sevier3 on fig. 10) allowed for spatially refined observations and required a separate observation for the rest of Sevier Desert (observation et39sevier1 on fig. 10; table 2). Observations for et39pavant and et39leaming were not changed, even though the method of simulation was changed. For consistency with previous versions, new ETg observations were assumed to have a coefficient of variation of 0.30 . Other ETg observations that were used in previous versions were not changed in GBCAAS v. 3.0.

Discharge is a negative value in MODFLOW-LGR, and all simulated equivalents of discharge determined by MODFLOW-LGR (rivers, springs, ETg simulated as drains, and lakes) are reported as negative values in this report to match model files. A larger discharge, therefore, is a more negative number. MODFLOW-LGR does not calculate simulated equivalents for ETg simulated with the Evapotranspiration Package; those simulated equivalents were derived using ZONEBUDGET (Harbaugh, 1990), which reports them as positive values. The UCODE_2014 input and output, therefore, also use positive values for those simulated equivalents (Brooks, 2017), but they are changed to negative values in this report.

To provide a better measure of model fit in the mountains east of Parowan, groundwater discharge to rivers in Parowan Valley (HA 281) and Cedar City Valley (HA 282) were divided into five observations (table 1-4; compare fig. 11 to Brooks and others, 2014, fig. 17). The total observed discharge was not changed, and the method used to determine the observations and variances was not changed from previous versions.

\section{Need for Recalibration}

To determine if recalibration of the model was needed to meet the model objectives in Parowan, Pine, and Wah Wah Valleys, the new observations of water levels and ETg were added to GBCAAS v. 2.0. The residuals between the simulated equivalents and the new observations, and the groundwater budget and water-level declines in Parowan Valley (HA 281) simulated using GBCAAS v. 2.0, indicated several areas that appeared to need model refinements.

Water-level residuals near Sevier Lake (fig. 15) indicated that simulated water levels were too low east of the lake and too high west of the lake. Residuals of discharge to ETg indicated too much discharge simulated near Sevier Lake (et39sevier3 on fig. 16) and too little discharge simulated in the rest of Sevier Desert (et39sevier1 and et39sevier2 on fig. 16), although previous model versions provided a good match to the previous observation of ETg for the entire Sevier Desert (table 2). The simulated equivalents of discharge to ETg and water levels indicated that previous versions provided too much flow to the area around Sevier Lake from the west and southwest and that less recharge should be simulated in Pine Valley (HA 255) and Wah Wah Valley (HA 256), that transmissivity from Wah Wah Valley to Sevier Desert should be reduced, or that both of those previously simulated values may be incorrect.

Water-level residuals in Pine Valley (fig. 15) indicated that transmissivity in Pine Valley should be increased, less recharge should be simulated, or that both of those previously simulated values may be incorrect. Water-level residuals (fig. 15) and simulated discharge to ETg of more than 160 percent of the observed discharge at et 37 snake 4 and less than 30 percent of observed discharge at et 37 snake3 (fig. 16) indicated that the system was not simulated correctly in southern Snake Valley. The large residuals of water levels and discharge to ETg simulated by GBCAAS v. 2.0 in Sevier Desert, Pine Valley, and Snake Valley demonstrated that the objectives of the model in this area to provide revised estimates of simulated recharge, hydraulic conductivity, and interbasin flow, and to simulate the effects of proposed groundwater withdrawals on the regional flow system could not be met without recalibration.

In the Great Basin carbonate and alluvial aquifer system conceptual budget, pre-development ETg in Parowan Valley (HA 281) was estimated to be 34,000 acre-ft/yr (Masbruch, 2011 b, table A5-1) on the basis of reported ETg and groundwater withdrawals in the 1970s (Bjorklund and others, 1978, p. 42 and 44). Masbruch and others (2011, p. 104) assumed that the system was in a new steady-state condition and that capture of natural discharge in areas with withdrawals was equal to 70 percent of the reported withdrawals. Pre-development ETg, therefore, was assumed to be the total of the reported ETg plus 70 percent of reported withdrawals. These estimates were made because at the regional scale of the Great Basin carbonate and alluvial aquifer system, detailed analysis for each HA was not included in the project scope. Recent analyses in Parowan Valley, however, indicated the following problems with the estimate of 34,000 acre-ft/yr: (1) the system was not in steady-state in the 1970 s and water was being released from storage (Marston, 2017, fig. 10) and (2) the estimate of ETg made in the 1970s included use of precipitation by vegetation. An estimated ETg of 8,700 acre-ft/yr (Thomas and Taylor, 1946, p. 168-172) during the steady-state period of GBCAAS v. 3.0 is more reasonable. Also, recent well withdrawals of about 33,000 acre-ft/yr have caused continuous water-level declines, indicating that pre-development natural discharge was less than 33,000 acre-ft/yr. On the basis of the revised estimate of ETg and declining water levels in Parowan Valley, it is likely that recharge should be reduced in the groundwater model. These changes in the conceptual budget and the objective to estimate reduction in groundwater storage in Parowan Valley required that the model be recalibrated. 


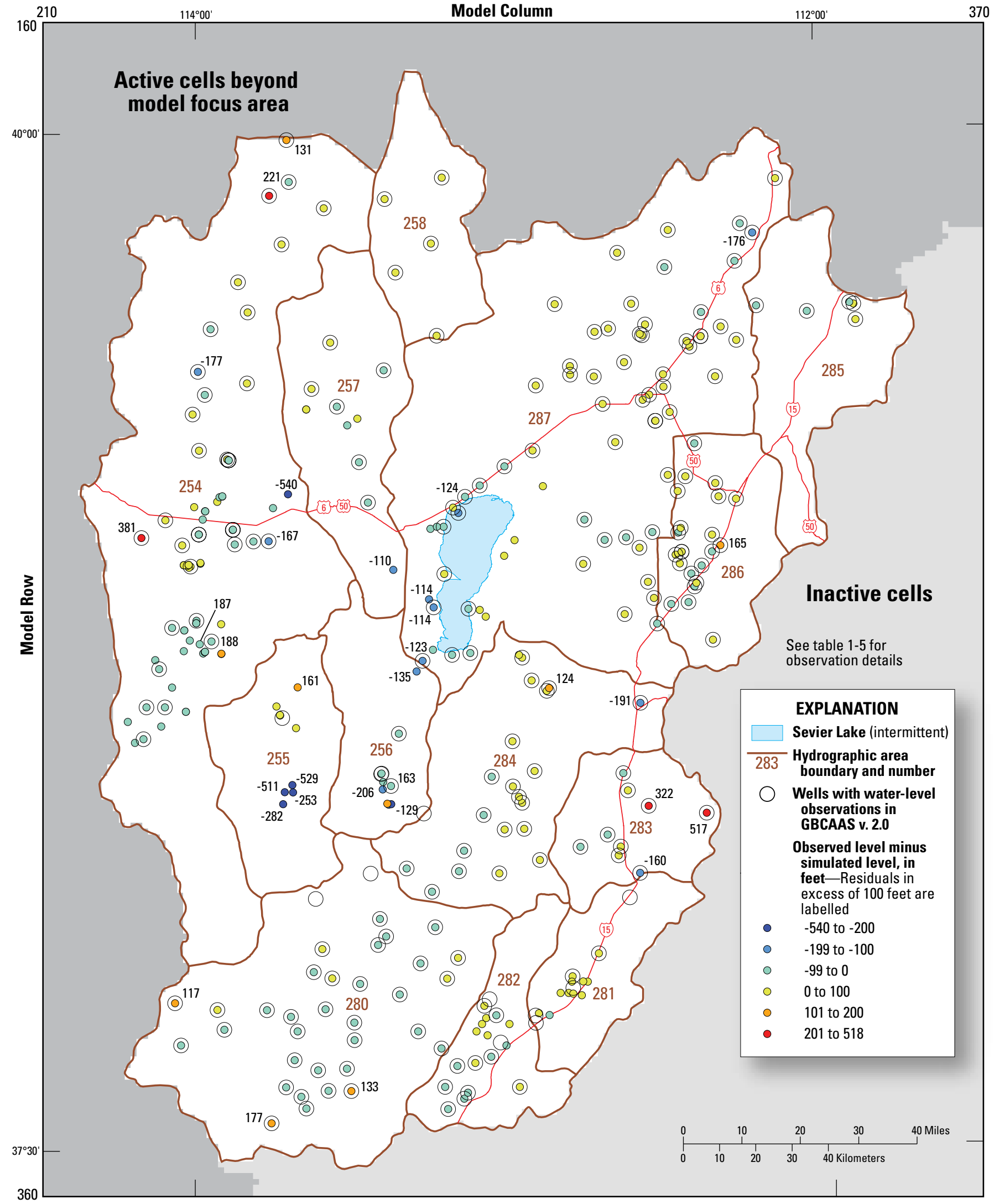

Figure 15. Steady-state water-level residuals using the GBCAAS v. 2.0 groundwater model, model focus area, Utah and Nevada. 


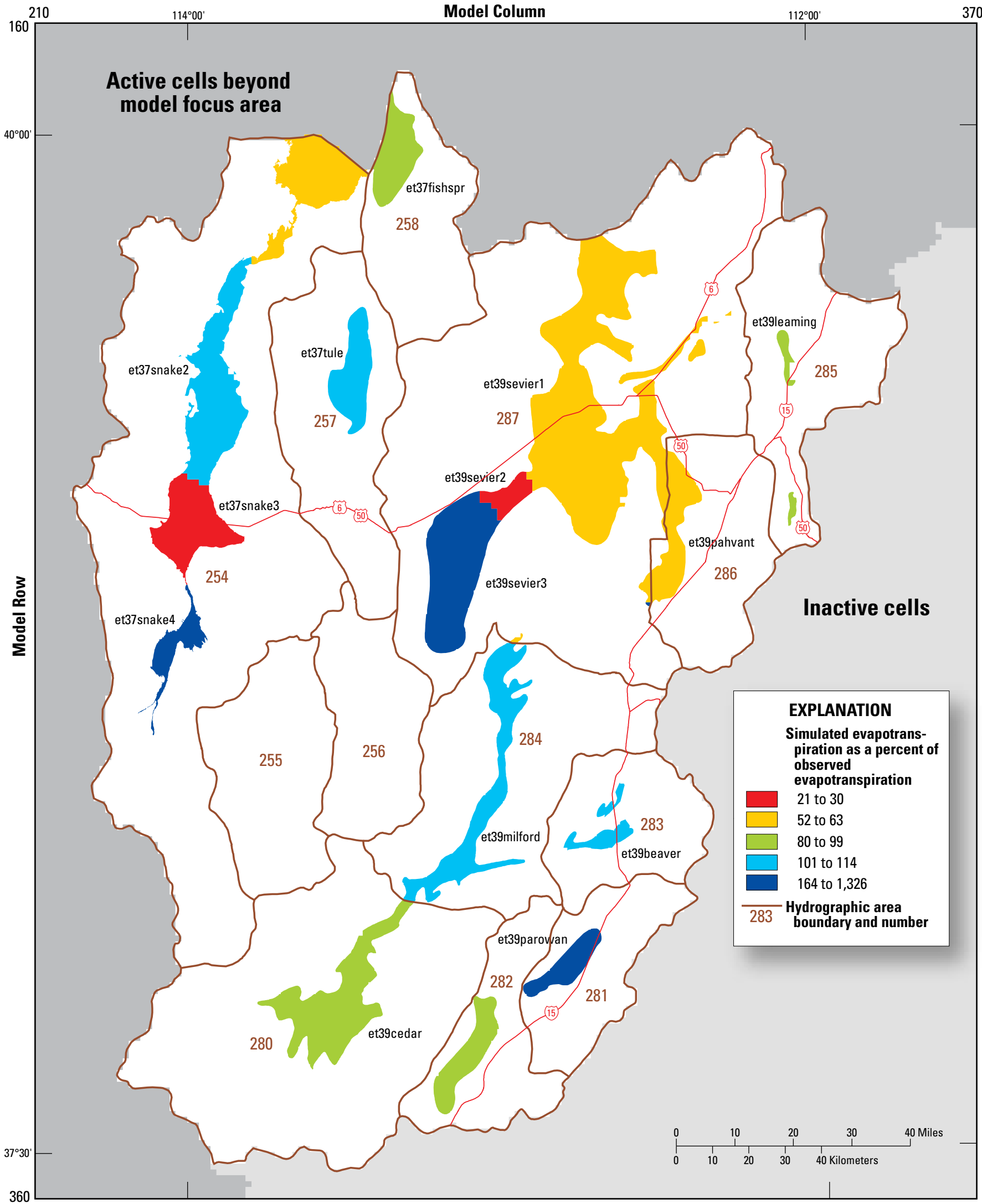

Figure 16. Steady-state evapotranspiration simulated by the GBCAAS v. 2.0 groundwater model, as percent of observed evapotranspiration, model focus area, Utah and Nevada. 


\section{Calibration}

The purpose of the model calibration for this study was to develop a model that reasonably represents groundwater recharge, movement, and discharge throughout the model focus area, and changes in storage in Parowan Valley (HA 281). During calibration, model parameters were changed to adjust the value and distribution of recharge, horizontal hydraulic conductivity, vertical anisotropy, river conductance, and rate of ETg. The location and conductance of horizontalflow barriers were also adjusted. Attempts were made to limit the changes to simulated values at observations outside of the model focus area; as a result, some parameter zones or values were changed in areas outside, but near, the model focus area.

\section{Method}

For the calibration of GBCAAS v. 3.0, an abbreviated version of the calibration methods described for GBCAAS v. 1.0 (Brooks and others, 2014, p. 38-40) was used. Calibration included nonlinear regression using UCODE_2014 (Poeter and others, 2014) and manual adjustment of parameter zones and selected parameter values, typically after examining results of nonlinear regression. In general, nonlinear regression was used to guide selection of parameter values; composite scaled sensitivities were used to guide separation and combination of parameters; and influence statistics were used to guide parameter zonation. Reasonable parameter values (tables 4 and 5) in GBCAAS v. 3.0 are the same as in GBCAAS v. 2.0 (Stolp and others, 2017, tables 11 and 12), with the addition of reasonable ranges for pumping in Parowan Valley (HA 281) and for storage properties.

During calibration, the weights of some observations were changed to provide an even representation of different observation groups to the calibration process. As in previous versions (Brooks and others, 2014, p. 40; Stolp and others, 2017, p. 58), the weight of discharge observations was increased relative to water-level observations. This increased weighting is frequently done, especially for observations that provide unique information (Hill and Tiedeman, 2007, p. 301). In groundwater systems, discharge data provide information that reduces correlation among parameters (Hill and Tiedeman, 2007, p. 302). Most discharge observations were given a weight multiplier of 5.0, as in previous versions. The large number and small variances of drawdown observations caused regressed parameter estimates that resulted in simulated groundwater levels substantially below observed water levels in Parowan Valley during the steady-state period. To alleviate this problem, the drawdown observations in Parowan Valley (HA 281) were given a weight multiplier of 0.015 . The weight multipliers for discharge and drawdown allowed the information provided by each type of observation to be roughly proportional to the number of observations for each type (table 6).

For final analysis of sensitivity, parameter correlation, parameter confidence intervals, and prediction uncertainty of interbasin flow, prior information was used for 16 parameters (table 7) that could not be estimated by the model with a standard deviation less than the conceptual standard deviation (tables 4 and 5). Prior information was used to reflect a realistic degree of uncertainty in these 16 parameters (Hill and Tiedeman, 2007, p. 131).

\section{Parameter Values in Calibrated Model}

Parameters were added to describe well withdrawals in Parowan Valley and specific storage and specific yield of the nine hydrogeologic units. Most other differences from previous versions are in ETg, recharge, and horizontal hydraulic conductivity zones and parameter values. Changes to HFBs and vertical anisotropy of hydraulic conductivity have less variation from previous versions. The final model has 208 parameters; GBCAAS v. 2.0 had 186 parameters. Seven parameters are only in the HA273UTchild model and have no effect on the model focus area in this study. An additional four parameters are defined as derived parameters because independent parameters could not be estimated or were highly

Table 4. Horizontal hydraulic conductivity estimates for hydrogeologic units in the Death Valley regional groundwater flow system and the Great Basin carbonate and alluvial aquifer system study area.

[Modified from Belcher and others, 2002, table 1 and Brooks and others, 2014, table 3. Geometric mean and standard deviation are back-transformed from logarithmic values. Abbreviations: GBCAAS, Great Basin carbonate and alluvial aquifer system; DVRFS, Death Valley regional groundwater flow system; Hydrogeologic unit acronyms for Great Basin carbonate and alluvial aquifer system: UBFAU, upper basin-fill aquifer unit; LBFAU, lower basin-fill aquifer unit; VU, volcanic unit; UCAU, upper carbonate aquifer unit; LCAU, lower carbonate aquifer unit; TLCAU, thrusted lower carbonate aquifer unit; USCU, upper siliciclastic confining unit; NCCU, non-carbonate confining unit; TNCCU, thrusted noncarbonate confining unit. Hydrogeologic unit acronyms for Death Valley regional groundwater flow system: AA, alluvial aquifer; ACU, alluvial confining unit; YVU, younger volcanic rocks unit; VSU, volcaniclastic and sedimentary rocks unit; TV, Tertiary volcanic rocks; OVU, older volcanic rocks unit; UCA, upper carbonate aquifer; LCA, lower carbonate aquifer; UCCU, upper clastic confining unit; LCCU, lower clastic confining unit]

\begin{tabular}{|c|c|c|c|c|c|c|c|c|c|}
\hline \multirow{3}{*}{ GBCAAS hydrogeologic unit } & \multirow{3}{*}{$\begin{array}{l}\text { DVRFS } \\
\text { hydrogeologic } \\
\text { unit or subunit }\end{array}$} & \multicolumn{8}{|c|}{ Hydraulic conductivity (feet per day) } \\
\hline & & \multirow{2}{*}{$\begin{array}{c}\text { Geometric } \\
\text { mean }\end{array}$} & \multirow{2}{*}{$\begin{array}{c}\text { Arithmetric } \\
\text { mean }\end{array}$} & \multirow[t]{2}{*}{ Minimum } & \multirow[t]{2}{*}{ Maximum } & \multicolumn{2}{|c|}{$\begin{array}{c}\text { 95-percent confidence interval } \\
\text { (reasonable range) }\end{array}$} & \multirow{2}{*}{$\begin{array}{c}\text { Number of } \\
\text { measurements }\end{array}$} & \multirow{2}{*}{$\begin{array}{c}\text { Standard } \\
\text { deviation of } \\
\text { log values }\end{array}$} \\
\hline & & & & & & Low & High & & \\
\hline UBFAU, non-playa & AA & 4.9 & 35 & 0.0002 & 430 & 0.02 & 1,400 & 52 & 1.3 \\
\hline UBFAU, playa & $\mathrm{ACU}$ & 9.8 & 34 & 0.01 & 110 & 0.07 & 1,500 & 15 & 1.1 \\
\hline LBFAU & YVU/VSU & 0.2 & 4.9 & 0.0001 & 20 & 0.0002 & 260 & 15 & 1.6 \\
\hline \multirow{2}{*}{ VU } & TV & 0.4 & 13 & 7.E-06 & 590 & 0.0007 & 260 & 170 & 1.4 \\
\hline & OVU & 0.01 & 0.2 & 3.E-06 & 3.3 & 0.00007 & 16 & 46 & 1.4 \\
\hline UCAU, LCAU, and TLCAU & UCA and LCA & 8.2 & 300 & 0.0003 & 2,700 & 0.003 & 25,000 & 53 & 1.8 \\
\hline USCU, NCCU, and TNCCU & $\begin{array}{l}\text { UCCU and } \\
\text { LCCU }\end{array}$ & 0.00007 & 0.7 & 1.E-07 & 16 & 3.E-10 & 9.8 & 29 & 2.7 \\
\hline
\end{tabular}


Table 5. Estimates of properties describing parameter values for vertical anisotropy, horizontal-flow barriers, recharge, evapotranspiration, drains, rivers, withdrawals, and storage properties in the GBCAAS v. 3.0 groundwater model, Great Basin carbonate and alluvial aquifer system study area.

[Modified from Stolp and others, 2017, table 12. ETg, evapotranspiration from groundwater; —, not applicable; $\mathrm{ft}^{2} / \mathrm{d}$, square feet per day]

\begin{tabular}{|c|c|c|c|c|c|c|}
\hline \multirow[b]{2}{*}{ Parameter type } & \multirow[b]{2}{*}{ Parameter units } & \multicolumn{5}{|c|}{ Parameter value } \\
\hline & & Initial value & $\begin{array}{l}\text { Minimum } \\
\text { reasonable } \\
\text { range }\end{array}$ & $\begin{array}{c}\text { Maximum } \\
\text { reasonable } \\
\text { range }\end{array}$ & $\begin{array}{c}\text { Approximate } \\
\text { standard } \\
\text { deviation }\end{array}$ & $\begin{array}{c}\text { Approximate } \\
\text { standard } \\
\text { deviation of } \\
\text { log10 values }{ }^{1}\end{array}$ \\
\hline Vertical anisotropy of lower basin fill and consolidated rock & unitless & 1.00 & 0.10 & 10.00 & - & 0.50 \\
\hline Vertical anisotropy of upper basin fill & unitless & 10.00 & 1.00 & 5,000 & - & 1.40 \\
\hline Horizontal-flow barrier conductance & feet per day & 1.E-07 & $5.11 \mathrm{E}-13$ & 0.02 & - & 2.70 \\
\hline Recharge multiplier & unitless & 1.00 & 0.29 & 2.25 & 0.50 & - \\
\hline ETg conductance multiplier ${ }^{2}$ & unitless & 1.00 & 0.50 & 2.00 & - & 0.15 \\
\hline ETg rate multiplier ${ }^{3}$ & unitless & 1.00 & 0.50 & 2.00 & 0.50 & - \\
\hline Drain leakance $^{4}$ & per day & 1.00 & 0.0003 & 3,373 & - & 1.80 \\
\hline River conductivity ${ }^{5}$ & feet per day & 1.00 & 0.0003 & 3,373 & - & 1.80 \\
\hline River leakance $^{6}$ & per day & 1.00 & 0.0003 & 3,373 & - & 1.80 \\
\hline Withdrawal multiplier (Malad-Lower Bear River area) & unitless & 1.00 & 0.5 & 2 & 0.50 & - \\
\hline Withdrawal multiplier (Parowan Valley) & unitless & 1.00 & 0.5 & 1.5 & 0.50 & - \\
\hline Specific storage $^{7}$ & per feet & 1.E-07 & $1.50 \mathrm{E}-08$ & 0.063 & - & 1.70 \\
\hline Specific yield ${ }^{7}$ & unitless & 0.10 & 0.001 & 0.47 & - & 0.70 \\
\hline
\end{tabular}

${ }^{1}$ Parameters for which negative values are physically impossible are transformed during regression analysis.

${ }^{2}$ Parameters describing evapotranspiration simulated using the Drain Package.

${ }^{3}$ Parameters describing evapotranspiration simulated using the Evapotranspiration Package.

${ }^{4}$ Input to the Drain Package includes the area of the drain in each cell, which is multiplied by the parameter to get the value of conductance ( $\mathrm{ft} / \mathrm{d}$ ).

${ }^{5}$ Parameter incorporates riverbed hydraulic conducivity, riverbed thickness, and riverbed width into one value. Input to the River Package for the parent model includes the length of river in each cell which is multiplied by the parameter to get the value of conductance ( $\left.\mathrm{ft}^{2} / \mathrm{d}\right)$.

${ }^{6}$ Parameter incorporates riverbed hydraulic conductivity and riverbed thickness into one value. Input to the River Package for the child model includes the area of river in each cell, which is multiplied by the parameter to get the value of conductance $\left(\mathrm{ft}^{2} / \mathrm{d}\right)$.

${ }^{7}$ Range from Faunt and others, 2010, table F-14. Standard deviation calculated from range.

correlated. One of these is for spring conductance in the HA273UTchild model and has no effect on the model focus area. The other three are the pumping parameters in southern Parowan Valley for stress periods 1, 4, and 16. These are derived as 1.1, 0.6, and 1.3 times the pumping parameter for all other stress periods and do not have independent statistics generated by UCODE_2014. The adjustments were needed to provide a better match between simulated and observed waterlevel changes during those periods. Although UCODE 2014 was used to determine the value of most parameters, manual adjustments and nonlinear regression were stopped when changes made little improvement to model fit. Improvement in model fit considered not only the objective function (sum of squared residuals), but also hydrologic judgement. For example, parameter values that created larger areas of simulated water levels above land surface were less preferable even if they reduced the residual of specific simulated equivalents. Detailed descriptions of parameter values and statistics are provided in appendix 2. Detailed maps of parameter zones and values are not provided in this report, but data to visualize the distributions are available as GIS data in Brooks (2017).

Final model parameters have little correlation, which indicates that the parameters can be determined independently of each other. No parameters have correlation coefficients exceeding 0.95 , and only three pairs (rch117 and et_marshes, rch364 and nccu11hk, and rch272 and LCAU612HK) have correlation coefficients exceeding 0.85 . Of these six parameters, only nccullhk is in the model focus area.

Composite scaled sensitivities (fig. 17) indicate the observations of discharge to rivers and springs provide more information about model parameters in the model focus area than do water-level observations. This is consistent with previous versions of the model (Brooks and others, 2014, fig. 21 and Stolp and others, 2017, fig. 31) and with another model in the area (Masbruch and others, 2014, fig. 32). Water levels and water-level changes, however, provide the only information about specific yield and specific storage parameters and provide more information about recharge and withdrawals in Parowan Valley (HA 281) than any other observation group. Linear confidence intervals of parameters (fig. 18) indicate the simulated values provide enough information to constrain most of the parameters in the model focus area to smaller ranges than the conceptual constraints, and that most of the parameter values are within reasonable ranges (fig. 18; tables 4 and 5). Because the model is nonlinear, these confidence intervals are not exact, but the error cannot be easily quantified. Poeter and others $(2008$, p. 26) stated that the 95 -percent interval may in reality reflect a 99 - or 50-percent significance level. Christensen and Cooley (1999) stated that nonlinear effects can cause the nonlinear intervals to be asymmetric and either larger or smaller than the linear approximations. 
Table 6. Summary statistics for measures of model fit in the GBCAAS v. 3.0 groundwater model, model focus area, Utah and Nevada. [SOSWR, sum of squared weighted residuals; Nobs, number of observations; ETg, evpotranspiration from groundwater; —, not applicable]

\begin{tabular}{|c|c|c|c|c|c|c|c|c|c|c|}
\hline \multirow[b]{2}{*}{ Type of observation } & \multirow[b]{2}{*}{$\begin{array}{l}\text { Number of } \\
\text { observations }\end{array}$} & \multicolumn{2}{|c|}{ Unweighted residuals } & \multicolumn{5}{|c|}{ Weighted residuals } & \multirow[b]{2}{*}{$\begin{array}{c}\text { Percent of } \\
\text { number of } \\
\text { observations }\end{array}$} & \multirow[b]{2}{*}{$\begin{array}{l}\text { Percent of } \\
\text { total sum } \\
\text { of squared } \\
\text { weighted } \\
\text { residuals }\end{array}$} \\
\hline & & $\begin{array}{l}\text { Average } \\
\text { residual' }\end{array}$ & $\begin{array}{l}\text { Average residual } \\
\text { as percent of } \\
\text { range (for water } \\
\text { levels) or } \\
\text { average } \\
\text { (for discharge) }\end{array}$ & $\begin{array}{c}\text { Average } \\
\text { positive } \\
\text { weighted } \\
\text { residual }\end{array}$ & $\begin{array}{c}\text { Average } \\
\text { negative } \\
\text { weighted } \\
\text { residual }\end{array}$ & $\begin{array}{c}\text { Average } \\
\text { weighted } \\
\text { residual }\end{array}$ & SOSWR & 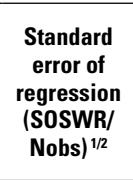 & & \\
\hline \multicolumn{11}{|c|}{ Water levels ${ }^{2}$} \\
\hline $\begin{array}{l}\text { Water levels in wells in steady-state } \\
\text { and transient periods }\end{array}$ & 371 & 11. & 0.2 & 3.17 & -3.22 & 0.59 & 8,000 & 4.64 & 50. & 43. \\
\hline Spring and river altitudes ${ }^{3}$ & 29 & 88. & 2.0 & 5.23 & -0.002 & 3.06 & 859 & 5.44 & 4. & 5. \\
\hline Total or weighted average & 693 & 9.8 & 0.7 & 3.6 & -3.43 & 0.55 & 18,104 & 5.11 & 93. & 98. \\
\hline \multicolumn{11}{|c|}{ Discharge $^{4}$} \\
\hline Spring discharge & 21 & $-29,615$ & 5.5 & 1.63 & -1.58 & -0.66 & 97. & 2.15 & 2.8 & 0.5 \\
\hline River discharge & 15 & $-7,711$ & 1.2 & 1.32 & -2.30 & -0.12 & 106. & 2.66 & 2. & 0.6 \\
\hline Lake discharge & 1 & $-129,284$ & 49. & - & -3.68 & -3.68 & 14. & 3.68 & 0.1 & 0.1 \\
\hline Total or weighted average & 54 & $-146,996$ & 8. & 1.36 & -1.94 & -0.82 & 333.1 & 2.48 & 7. & 2. \\
\hline \multicolumn{11}{|c|}{ All observations } \\
\hline Total or average & 747 & - & - & 3.44 & -3.32 & 0.45 & 18,437 & 4.97 & - & - \\
\hline
\end{tabular}

${ }^{1}$ In feet for water levels and cubic feet per day for discharge.

${ }^{2}$ Positive water-level residual indicates simulated value is less than observed value.

${ }^{3}$ Spring and river altitudes are only included as observations if at some point in calibration the spring or river was not discharging enough water; therefore, simulated values are usually below observed values and can only be slightly above observed values.

${ }^{4}$ Positive discharge residual indicates simulated discharge is more than observed discharge (greater negative value).

${ }^{5}$ Regression statistics as calculated by Zonebudget and UCODE are opposite in sign compared to other discharge observations. For this table, the statistics were multiplied by -1 to present statistics consistent with other discharge observations.

Table 7. Prior information statistics for selected parameters in the GBCAAS v. 3.0 groundwater model, Great Basin carbonate and alluvial aquifer system study area.

[Prior value: unitless for well, recharge, ETg, and specific yield parameters; feet per day for hydraulic conductivity parameters; per foot for specific storage parameter. Standard deviation: of the value for well, recharge, and ETg rate mulitplier parameters; of the log of the value for hydraulic conductivity, ETg conductance multiplier, specific storage, and specific yield parameters. Standard deviation without prior: From UCODE_2014 (Poeter and others, 2014). Abbreviations: HA, hydrographic area; ETg, evapotranspiration from groundwater]

\begin{tabular}{|c|c|c|c|c|c|}
\hline Parameter type & Parameter name & Prior value & $\begin{array}{l}\text { Standard } \\
\text { deviation }\end{array}$ & Location & $\begin{array}{l}\text { Standard deviation } \\
\text { without prior }\end{array}$ \\
\hline Well & pumpage273 & 1.0 & 0.5 & HA 273 & 0.88 \\
\hline Recharge & rchrun 2721 & 66.5 & 0.5 & Small part of HA 272 & 25. \\
\hline Recharge & rchrun2722 & 24.1 & 0.5 & Small part of HA 272 & 15. \\
\hline Recharge & $\operatorname{rch} 275$ & 6.64 & 0.5 & HAs 275,276 , small part of 273 & 1.2 \\
\hline \multicolumn{6}{|c|}{ Parameters only in GBCAASv3parent model } \\
\hline Recharge & $\operatorname{rch} 2812$ & 0.99 & 0.5 & Part of HA 281 & 0.72 \\
\hline Recharge & rchirr281 & 0.58 & 0.5 & Part of HA 282 & 0.54 \\
\hline Recharge & rchirr281B & 0.92 & 0.5 & Part of HA 283 & 0.6 \\
\hline Recharge & $\operatorname{rch} 282$ & 1.82 & 0.5 & Part of HA 282 & 0.77 \\
\hline Hydraulic conductivity & ucau31hk & 0.0005 & 1.8 & Near Lake Mead & 3.1 \\
\hline ETg conductance multiplier & et268 & 0.99 & 0.15 & HA 268 & 0.17 \\
\hline ETg rate multiplier & EVT_parowan & 2.1 & 0.5 & HA 281 & 1.1 \\
\hline ETg rate multiplier & EVT4 & 4. & 0.5 & HAs $254,285,287$ & 1.2 \\
\hline
\end{tabular}



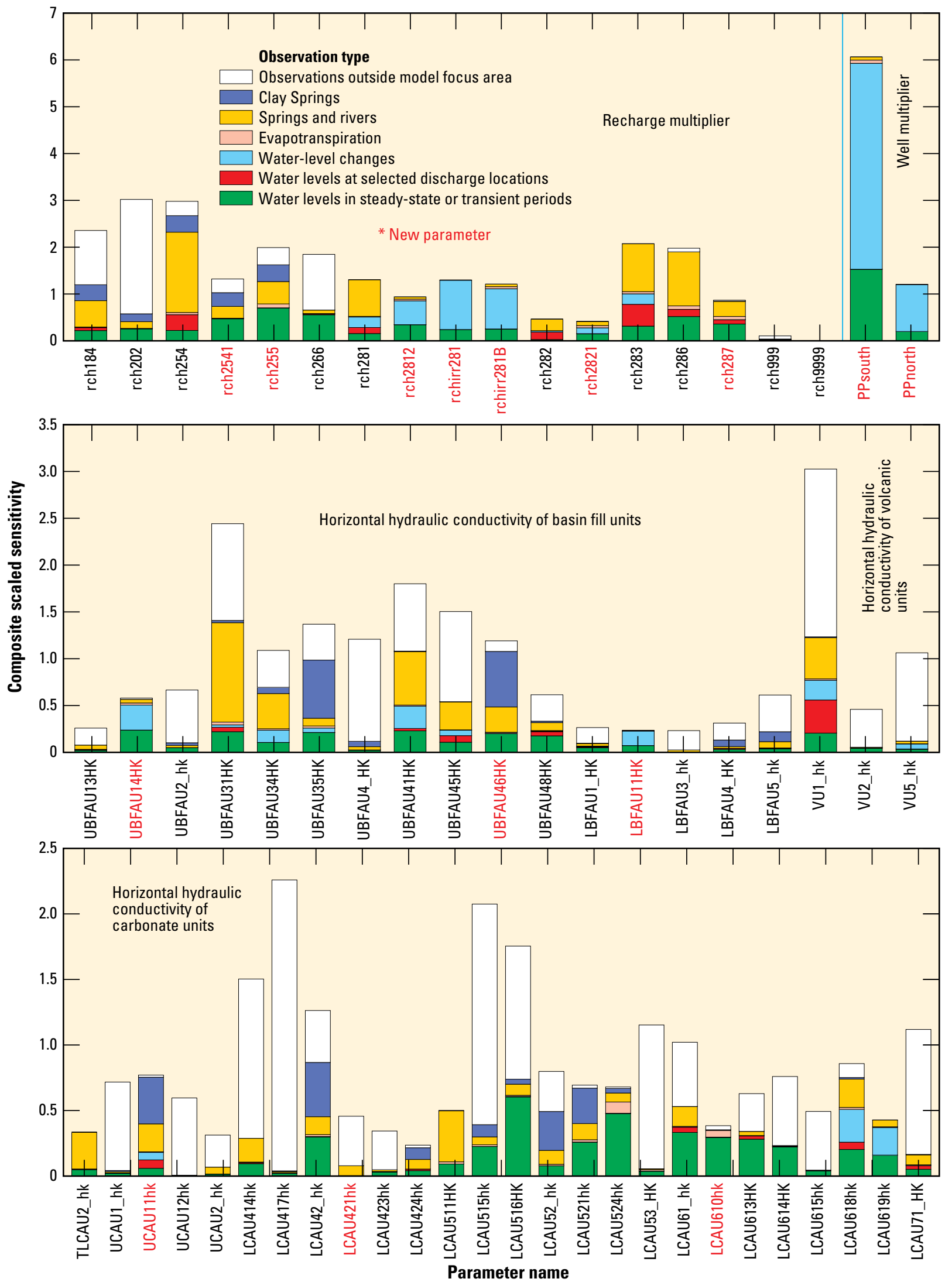

Figure 17. Composite scaled sensitivities of final parameters in the GBCAAS v. 3.0 groundwater model, model focus area, Utah and Nevada. 

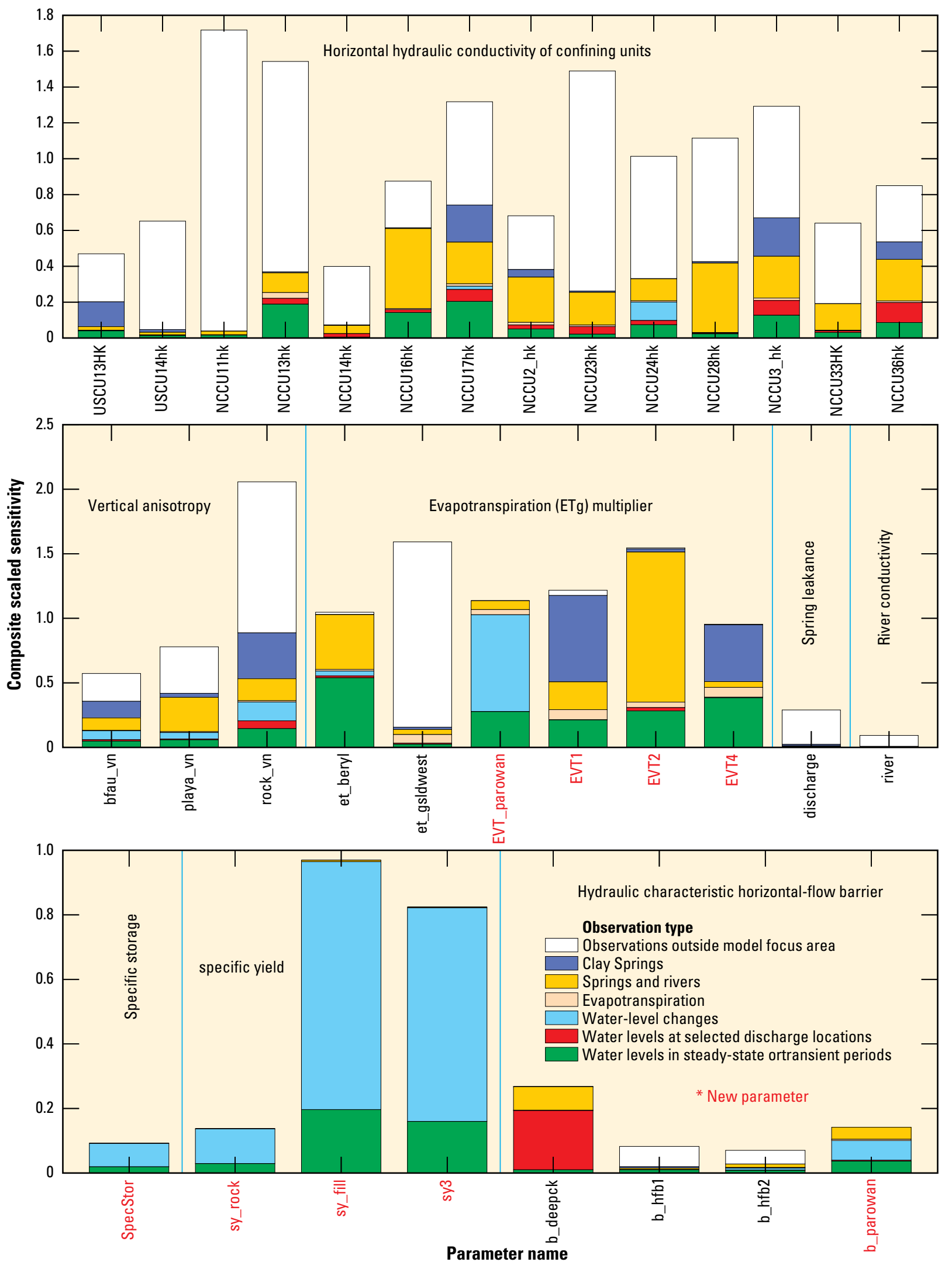

Figure 17. Composite scaled sensitivities of final parameters in the GBCAAS v. 3.0 groundwater model, model focus area, Utah and Nevada.-Continued 


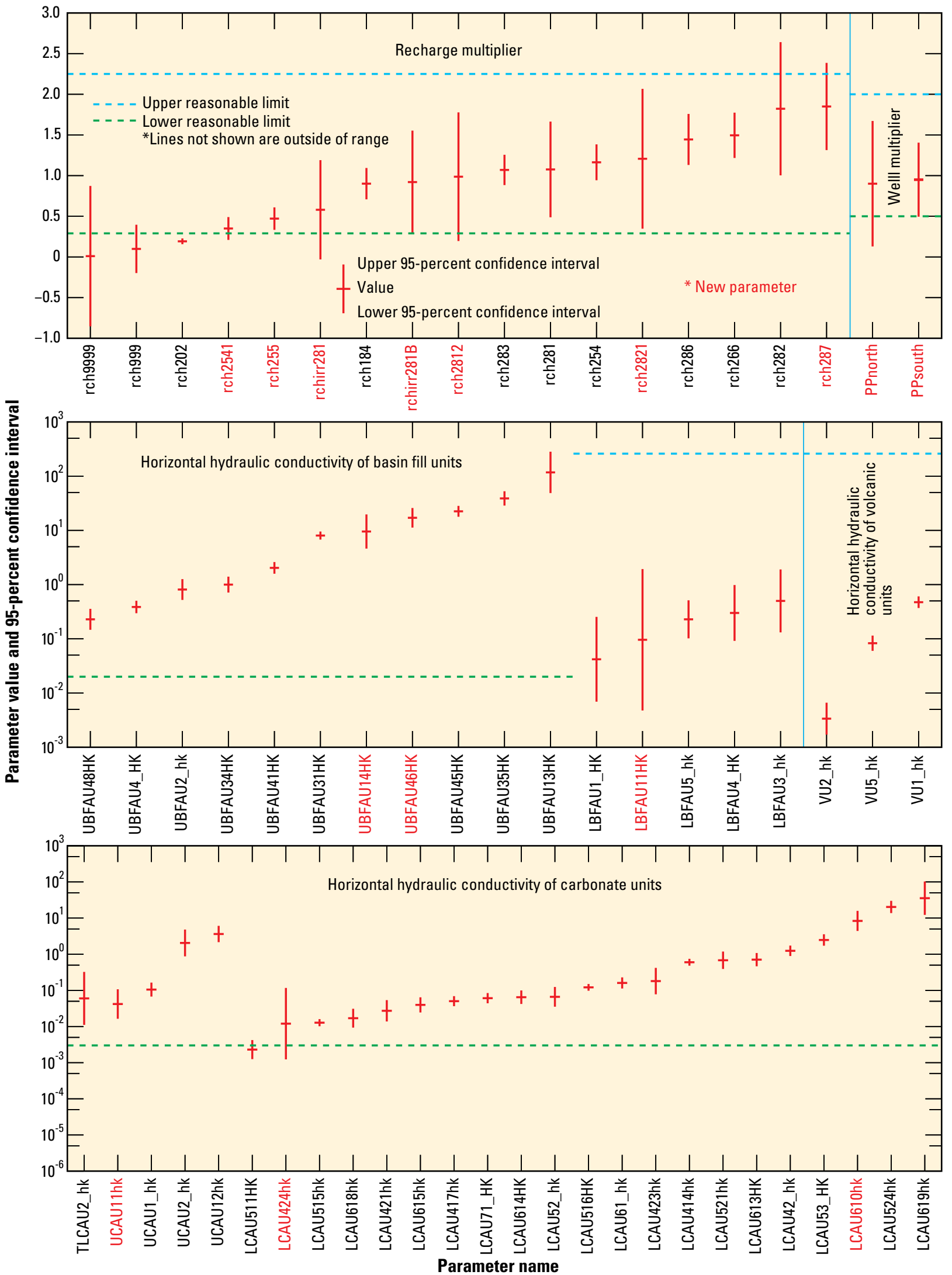

Figure 18. Values and linear confidence intervals of final parameters in the GBCAAS v. 3.0 groundwater model, model focus area, Utah and Nevada. 

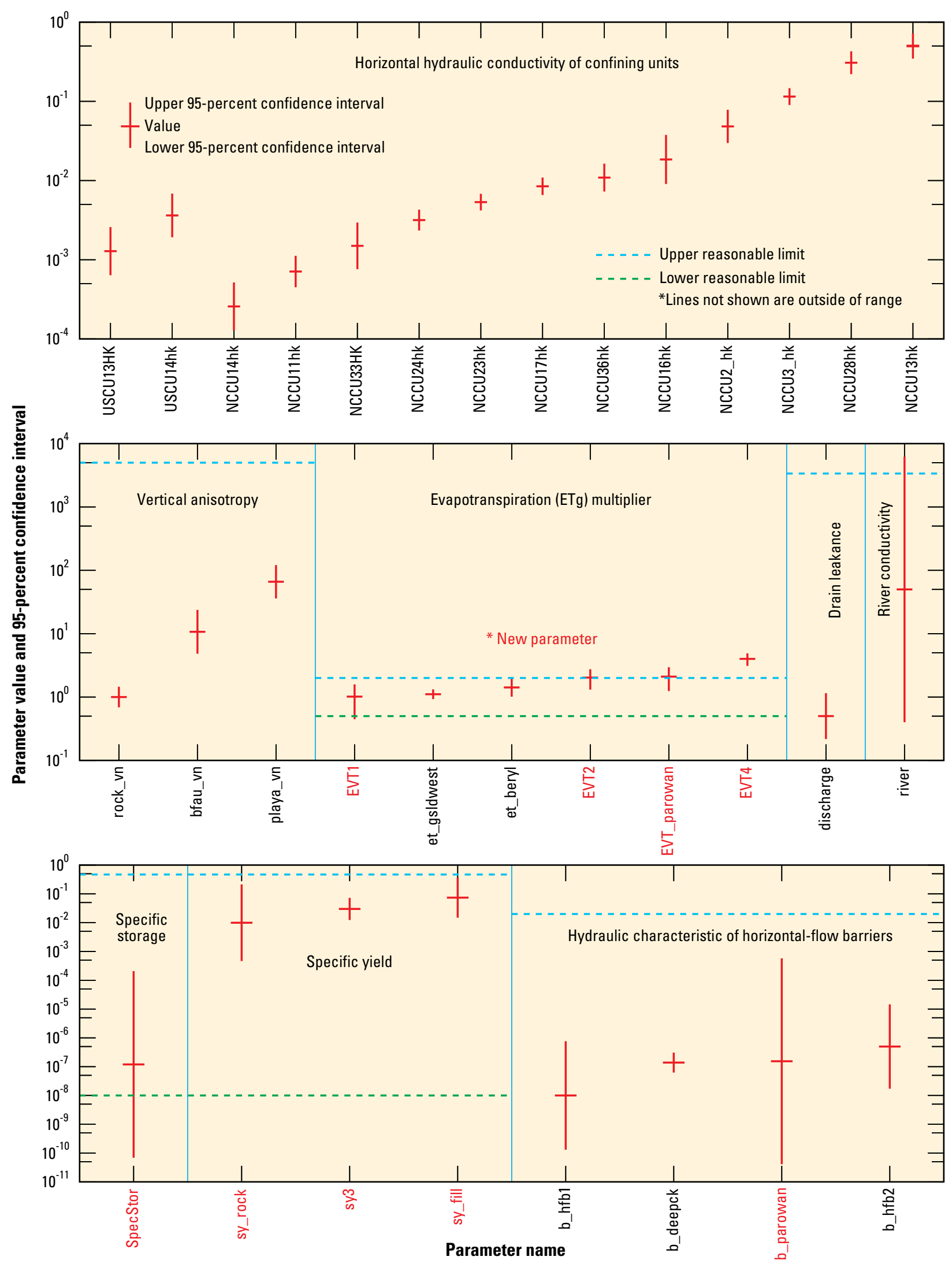

Figure 18. Values and linear confidence intervals of final parameters in the GBCAAS v. 3.0 groundwater model, model focus area, Utah and Nevada.-Continued 


\section{Model Evaluation}

Recalibration resulted in differences in simulated water levels throughout the model focus area compared with previous versions (fig. 19). Simulated changes of more than $10 \mathrm{ft}$ occur outside of the model area, but only in a limited area. The limited effects of these water-level changes on simulated equivalents to observations outside the model focus area can be seen in tables $1-5$ and 1-6, but are not discussed in this report. The simulated potentiometric surface in layer 1 in the steady-state period (fig. 20) shows little overall change from previous model versions (Brooks and others, 2014, plate 1). The 5,300-ft contour extends farther south in Pine Valley (HA 255), and the 4,800-ft contour extends farther south between Wah Wah Valley (HA 256) and Milford Area (HA 284), but then extends north around the mountains east of Sevier Lake. The addition of the 100-ft contours clearly shows the flat groundwater-level gradient from Wah Wah Valley to Tule Valley (HA 257) and Sevier Desert (HA 287) and the steeper gradients from Snake Valley (HA 254) to Wah Wah Valley and southern Tule Valley. Discussion of the water movement in the area and conceptual potentiometric maps can be found in Heilweil and Brooks (2011, pl. 2), Sweetkind and others (2011b), and Gardner and others (2011).

After recalibration, the model was evaluated to assess the accuracy of simulated results by evaluating the model fit to observations of water levels and discharge. Results of this evaluation, as detailed in following sections, indicated this model provides a reasonable representation of the groundwater system. This report discusses the evaluation of the model in the model focus area (fig. 1). Brooks and others (2014) and Stolp and others (2017) provide evaluations of other areas. Model fit to observations (table 6) was evaluated using unweighted and weighted residuals (the difference between observed and simulated values). Unweighted residuals have the same dimensions as the observations and are clearly understood, but they can be misleading because observations may be measured with different accuracy. Two unweighted residuals that are of equal value may not indicate an equally satisfactory model fit.

Weighted residuals were used in summary statistics (table 6) and regression. Weighted residuals are dimensionless quantities that reflect model fit in the context of the expected accuracy of the observations (Hill and Tiedeman, 2007, p. 35). A weighted residual of 2.0, for example, indicates that the unweighted residual is twice the observation error, where the error is defined as standard deviation. For each type of observation, the square root of the sum of square weighted residuals (SOSWR; table 6) divided by the number of observations (Nobs) is called the standard error of the regression (Hill and Tiedeman, 2007, p. 95) and provides a measure of model fit relative to the weighting that can be compared for different types of observations. A value of 1.0 indicates a match that is, overall, consistent with the analysis of observation error used to determine the weighting (Hill and Tiedeman, 2007, p. 96).
During calibration of GBCAAS v. 3.0, qualitative compromises between ETg and simulated water levels were made. In general, the model simulates too little ETg. Changes to the maximum ETg rate made little difference, and adding more recharge caused simulated water-level equivalents, especially near Sevier Lake (southern HA 287) and in southern Snake Valley (HA 254), to be higher than observed water levels in wells. Despite the low simulated ETg, however, the standard errors of the regression for each observation group (table 6) indicate that the model fits discharge observations better than water-level observations.

Weighted residuals are expected to be random and normally distributed (Hill and Tiedeman, 2007, p. 109). The correlation coefficient $\left(\mathrm{R}_{\mathrm{N}}^{2}\right)$ between the weighted residuals and the normal order statistics, as calculated by UCODE_2014 for GBCAAS v. 3.0 model, is 0.952 . This is less than the required 0.987 (Hill and Teideman, 2007, table D.3), which indicates the residuals are not normally distributed. Histograms of the residuals (fig. $21 A-C$ ), however, indicate that the distribution is close to normal.

\section{Model Fit to Water-Level Observations}

Because the goal of the recalibration for the Pine Valley (HA 255) and Wah Wah Valley (HA 256) area was to improve the model fit to observations that were not included in previous model versions, figure 20 shows the model fit to the same observations as shown on figure 15. Recalibration substantially reduced model residuals for steady-state water levels in Pine Valley, Wah Wah Valley, southern Tule Valley (HA 257), and Sevier Desert (HA 287). Before recalibration, 12 observations had residuals of greater than $100 \mathrm{ft}$; after recalibration, only 2 observations have residuals of greater than $100 \mathrm{ft}$. Minor improvements in model fit to steady-state head observations were also made in Snake Valley (HA 254), but model fit is slightly worse in Beryl-Enterprise Area (HA 280) and Milford Area (HA 284). For steady-state water-level observations in the model focus area that were in previous model versions and in GBCAAS v. 3.0, the sum of squared weighted residuals is less in GBCAAS v. 3.0 than in previous versions, indicating a better model fit to those water-level observations (table 1-5).

The fit of simulated to observed water levels is generally adequate for this regional model. The standard error of the regression of 4.64 for water levels in wells in the model focus area (table 6) multiplied by the average standard deviation of observations in wells of $12.7 \mathrm{ft}$ (table 3 ) indicate that the model has an overall fit to water levels in wells of $59 \mathrm{ft}$ (Hill and Tiedeman, 2007, p. 96). Of the simulated equivalents of water-level observations in wells, 85 percent are within $59 \mathrm{ft}$ (one standard deviation of the error) of the observation, and 95 percent are within $100 \mathrm{ft}$ (table 1-5; figs. 20 and 22). Graphs of weighted residuals and simulated values of water levels (fig. 21E) indicate little model bias. 


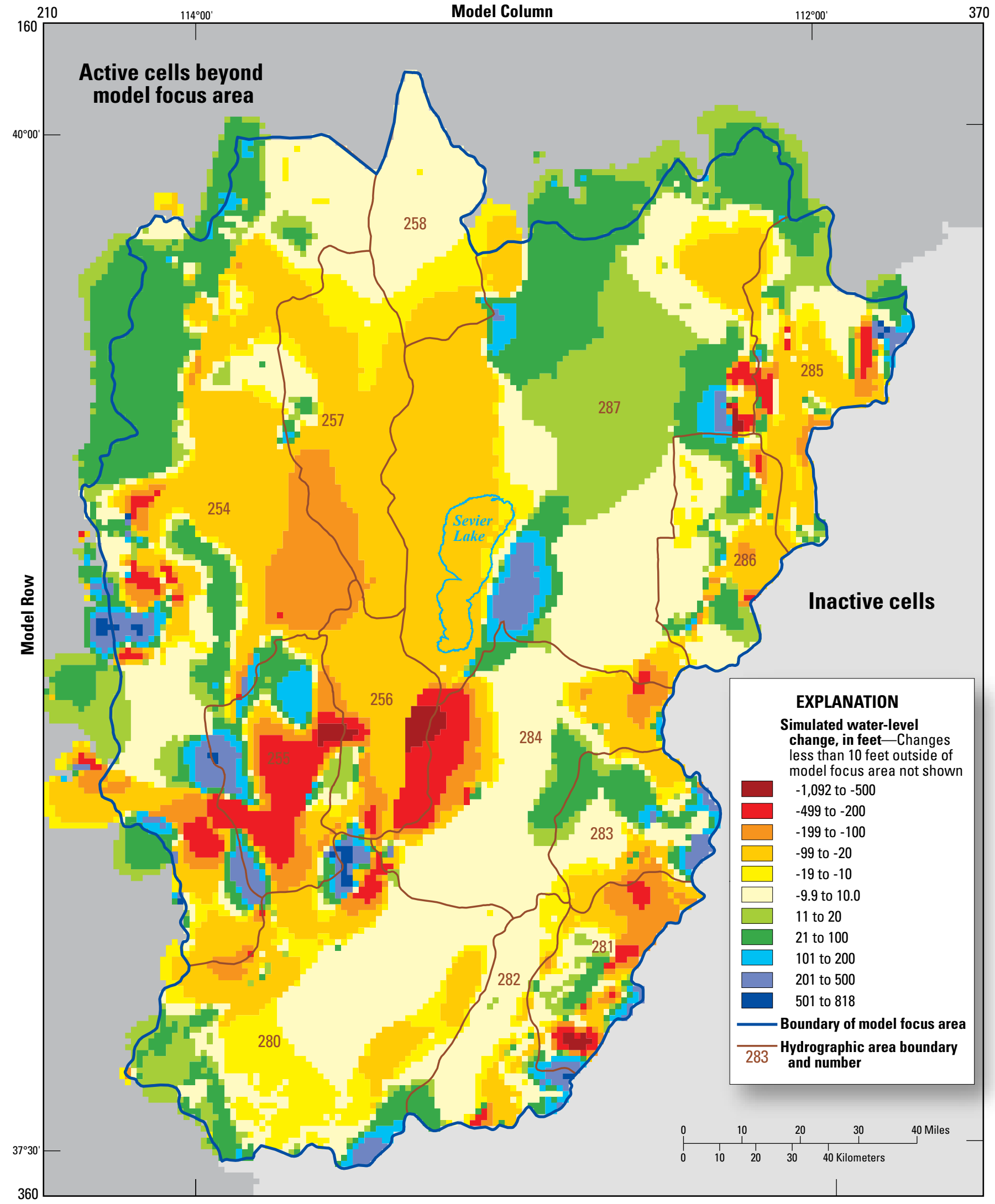

Figure 19. Simulated water-level change in layer 1 from GBCAAS v. 2.0 to the steady-state period of the GBCAAS v. 3.0 groundwater model, model focus area and surrounding areas, Utah and Nevada. 


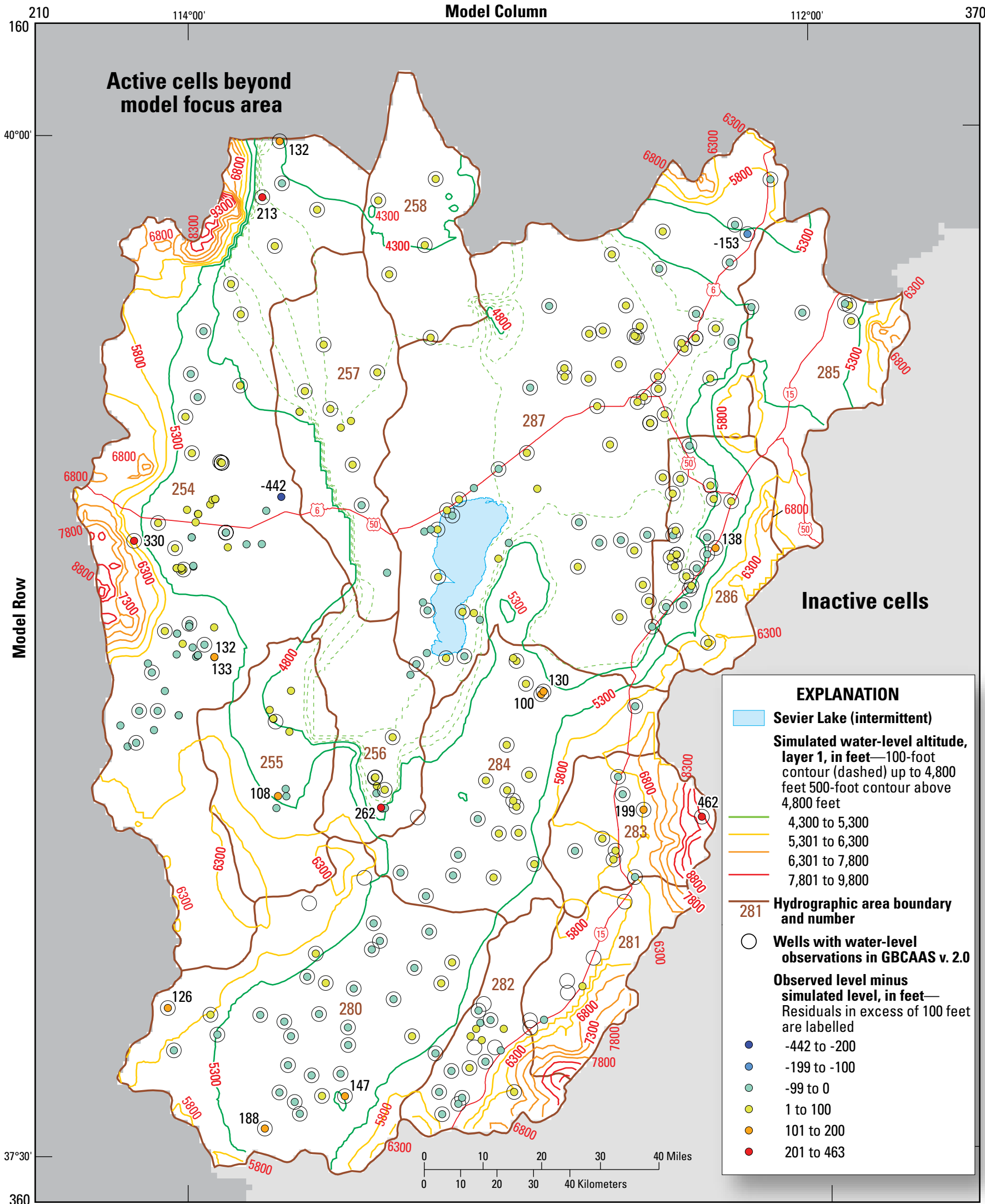

Figure 20. Simulated potentiometric surface and steady-state water-level residuals in the GBCAAS v. 3.0 groundwater model, model focus area, Utah and Nevada. 

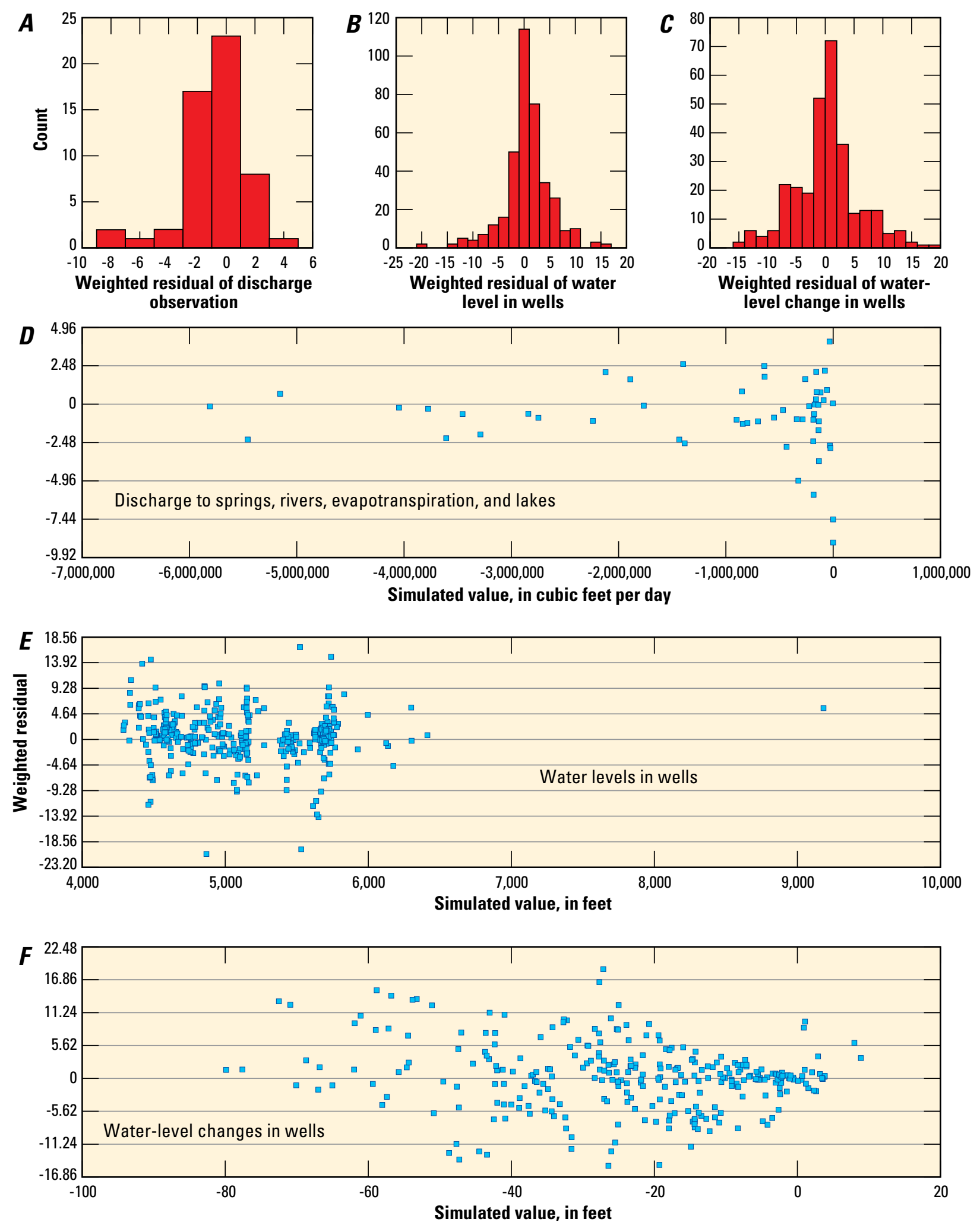

Figure 21. Weighted residuals in the GBCAAS v. 3.0 groundwater model, model focus area, Utah and Nevada. $A$, histogram of weighted residual of discharge; $B$, histogram of weighted residual of water level in wells; $C$, histogram of weighted residual of water-level change in wells; $D$, weighted residuals of discharge and simulated values; $E$, weighted residuals of water levels in wells and simulated values; and $F$, weighted residuals of water-level changes in wells and simulated values. 


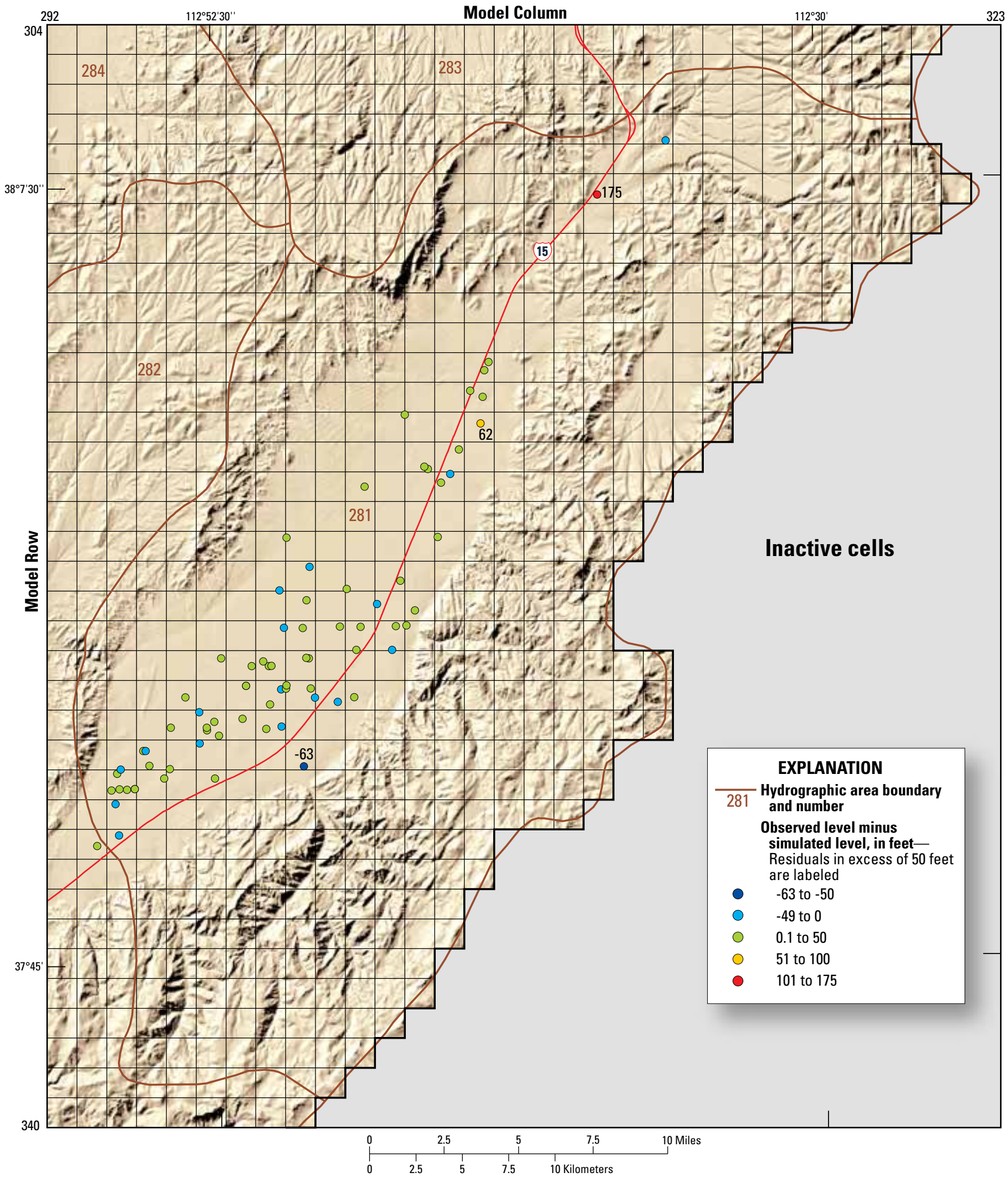

Figure 22. Water-level residuals in the GBCAAS v 3.0 groundwater model for the first water level in the transient periods, Parowan Valley, Utah. 


\section{Model Fit to Water-Level Changes}

The fit of simulated to observed water-level changes is generally adequate. The standard error of regression of 5.62 for water-level changes during transient periods (table 6), multiplied by the average standard deviation of the observations of 2.61 (table 3), indicate an overall model fit to these observations of $15 \mathrm{ft}$. Of the simulated values of observations of water-level changes in wells, 71 percent are within $15 \mathrm{ft}$ (one standard deviation of the error) of the observation, and 94 percent are within $30 \mathrm{ft}$ (two standard deviations; table 1-5). Graphs of weighted residuals and simulated values of water-level change (fig. $21 F$ ) indicate little model bias.

Simulated water levels and measured water levels are shown for 24 wells (fig. 23) in Parowan Valley (HA 281). The hydrographs (fig. 24) show that the model fits the overall trend of decreasing water levels and provides reasonable estimates of long-term reduction in storage and of storage changes from 2012 to 2013. The purpose of the transient model in Parowan Valley was to provide an estimate of reduction in storage from November 2012 to November 2013 (Marston, 2017). Earlier stress periods were used to help calibrate storage parameters, but changes in recharge and withdrawals rates were proportioned across the valley; attempts were not made to delineate pumping from each well in each year or recharge to each field in each year. Because of this generalization, individual simulated hydrographs might not match measured water levels because the complexities of the actual system are not in the model. In the southern part of the valley, which has the longest history of groundwater development, hydrographs 1-19 show good matches to water-level fluctuations, although some of them do not show enough water-level rise in the 1980s. This is likely caused by the model not including the complexities of surface-water routing and individual well withdrawals for those comparatively wet years. The close match of simulated to measured water-level fluctuations from November 2012 to November 2013 indicates that the model incorporates good representations of recharge, withdrawals, and storage changes during that period. In the northern part of the valley (hydrographs 21-24), simulated levels are lower than measured water levels, but water-level fluctuations are similar, indicating reasonable model estimates of storage properties.

In addition to water-level changes in individual wells, the overall simulated water-level changes from the steady-state period (representing the 1940s) to the end of stress period 16 (November 2013) were determined (fig. 25). The decrease in water levels shows a trend similar to that of the observed change in water levels from 1974 to 2013 (Marston, 2017, fig. 12), but with larger areas where decreases exceed $80 \mathrm{ft}$ in the southern part of the valley and 60 feet in the northern part of the valley. Hydrographs (fig. 24) indicate that observed and simulated water levels declined at least $20 \mathrm{ft}$ in several wells before 1973. Simulated water levels in parts of the mountains on the east side of Parowan Valley are higher at the end of stress period 16 (November 2013) than in the steadystate period. This is probably caused by the large amount of recharge simulated for model stress period 13 (fig. 6).

\section{Model Fit to Discharge Observations}

Calibration included matching groundwater discharge to ETg, springs, rivers, and lakes. The fit of simulated to observed discharge in the model focus area is generally good, although total discharge is 90 percent of total observed discharge (table 1-6). The total discharge simulated in the model focus area (fig. 1) is 95 percent of the discharge simulated by previous versions of the model. The conceptual discharge in the model focus area is also 95 percent of the previous conceptual discharge because conceptual ETg was reduced by about 33,000 acre- $\mathrm{ft} / \mathrm{yr}\left(3,900,000 \mathrm{ft}^{3} / \mathrm{d}\right.$; table 2$)$. The steady-state simulation of ETg was improved in the model focus area and has less extreme differences between simulated and observed values than before recalibration (fig. 26 compared to fig. 16). Simulated ETg is 86 percent of observed ETg in the model focus area (table 1-6). The steady-state simulated discharge to springs and rivers in the model focus area is 101 percent of observed discharge (table 1-6), and the residuals are more randomly distributed (fig. 27) than the residuals of discharge to ETg.

Simulated ETg in Sevier Desert (HA 287) is substantially less than observed ETg. The ETg estimates in Sevier Desert had about a 35 percent error (Philip Gardner, U.S. Geological Survey, written commun., July 21, 2016). In addition, around the Sevier River and Sevier Lake playa (observations et39sevier2 and et39sevier3 in table 2), surface water probably contributes to ET, and the ETg estimates may be larger than actual ETg. The estimate of observed ETg for the rest of Sevier Desert (observation et39sevier1 in table 2) may also be too large. Holmes (1984, p. 16) reported that ETg may be as little as 20,000 acre-ft/yr.

The standard error of the regression (table 6) for discharge observations of 2.48 multiplied by the weighted coefficient of variation of discharge observations of 0.12 (table 3 ) indicates a coefficient of variation of 0.30 , which is similar to the estimated error of 0.30 for the discharge observations. This indicates the model simulates discharge with as much accuracy as the observation estimates. Of the simulated discharges, 85 percent are within 30 percent of the observed values, and 94 percent are within 50 percent of the observed values (table 1-6). Graphs of weighted residuals and simulated values of discharge (fig. 21D) indicate little model bias; most of the weighted residuals vary randomly about a value of zero, but more residuals are negative than positive. This indicates the model generally simulates less discharge than observed. The apparent bias toward more model error with less discharge is an artifact of using similar coefficients of variation to determine variance and weight of the discharge observations. A smaller amount of discharge has less variance, a greater weight, and possibly a higher weighted residual under this method of weighting. 


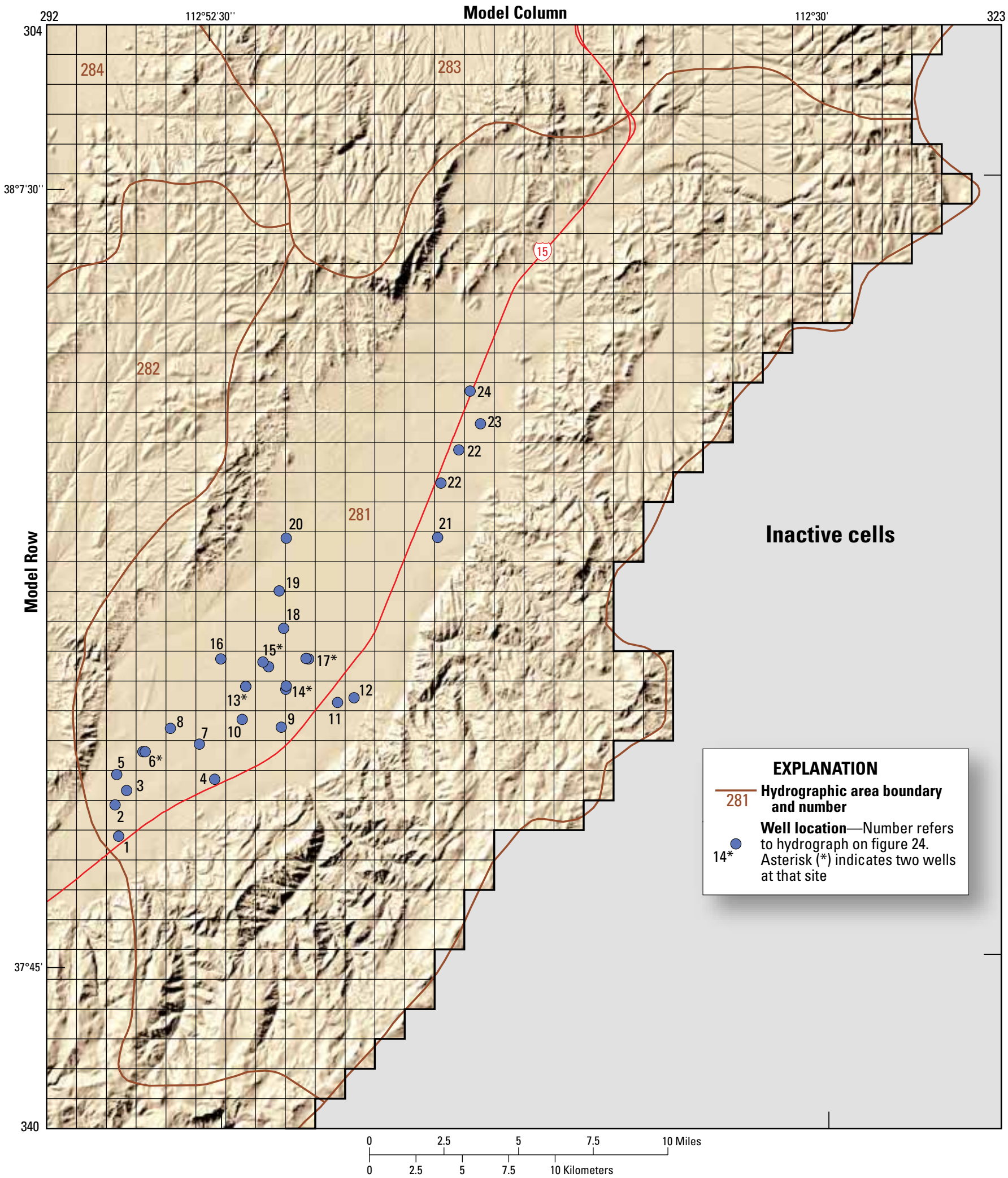

Figure 23. Location of selected wells used for comparison of measured and simulated water-level altitude in the transient periods of the GBCAAS v. 3.0 groundwater model, Parowan Valley, Utah. 

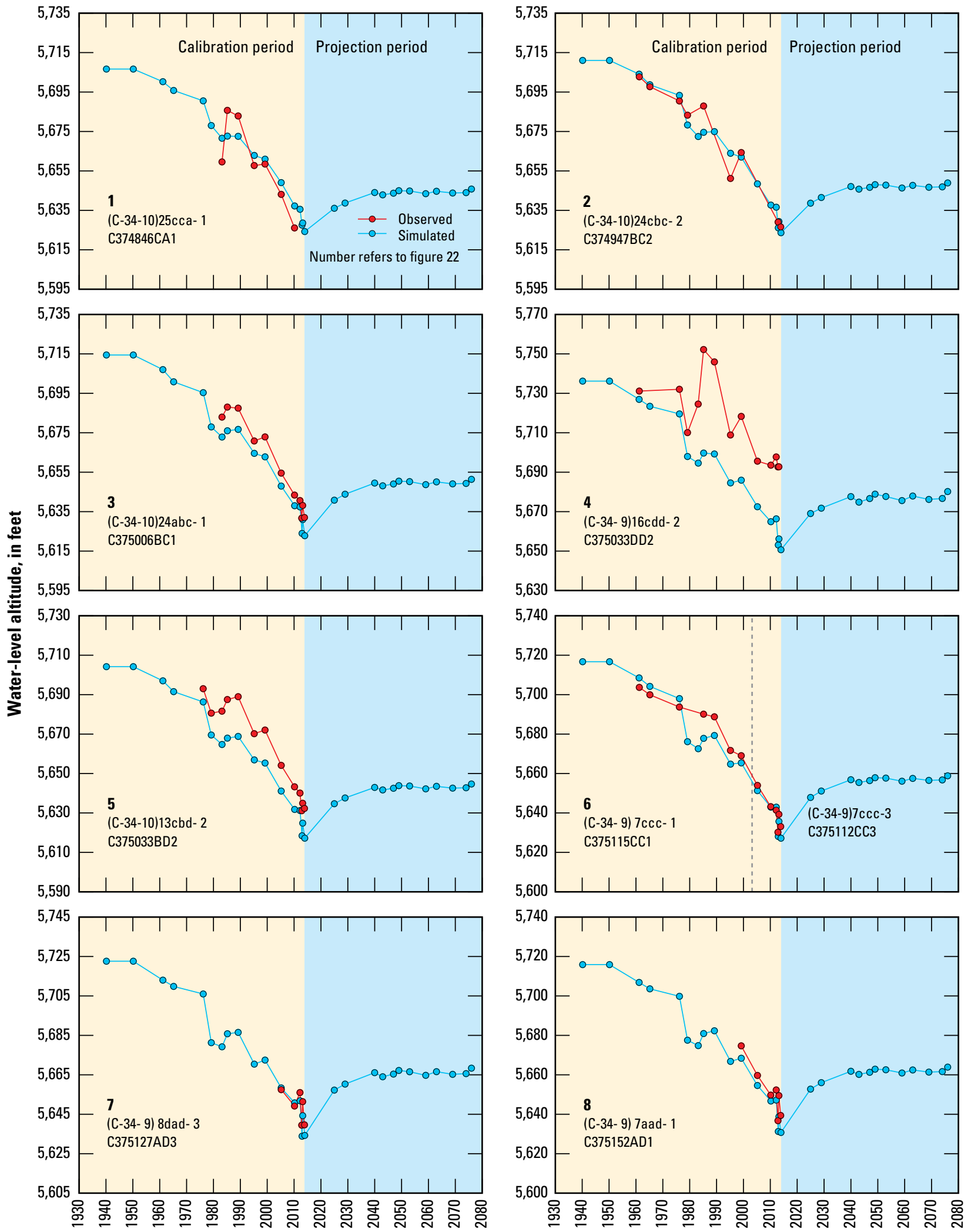

Replacement observation wells indicated by dashed vertical line and second well identification

Figure 24. Water-level altitudes simulated at the end of each stress period of the GBCAAS v. 3.0 groundwater model and measured water-level altitudes at selected wells during 1940 to 2013, Parowan Valley, Utah. 

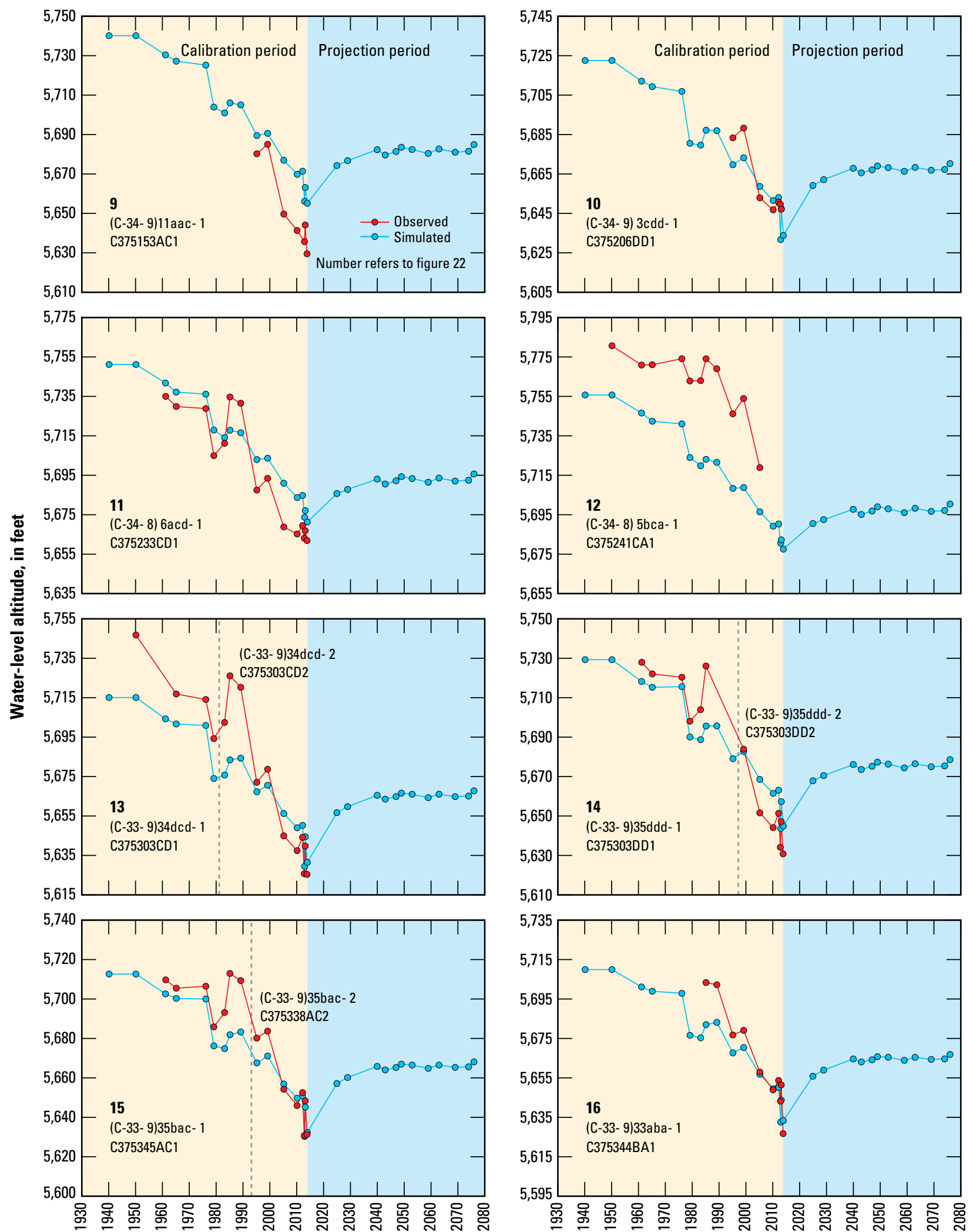

Replacement observation wells indicated by dashed vertical line and second well identification

Figure 24. Water-level altitudes simulated at the end of each stress period of the GBCAAS v. 3.0 groundwater model and measured water-level altitudes at selected wells during 1940 to 2013, Parowan Valley, Utah.—Continued 

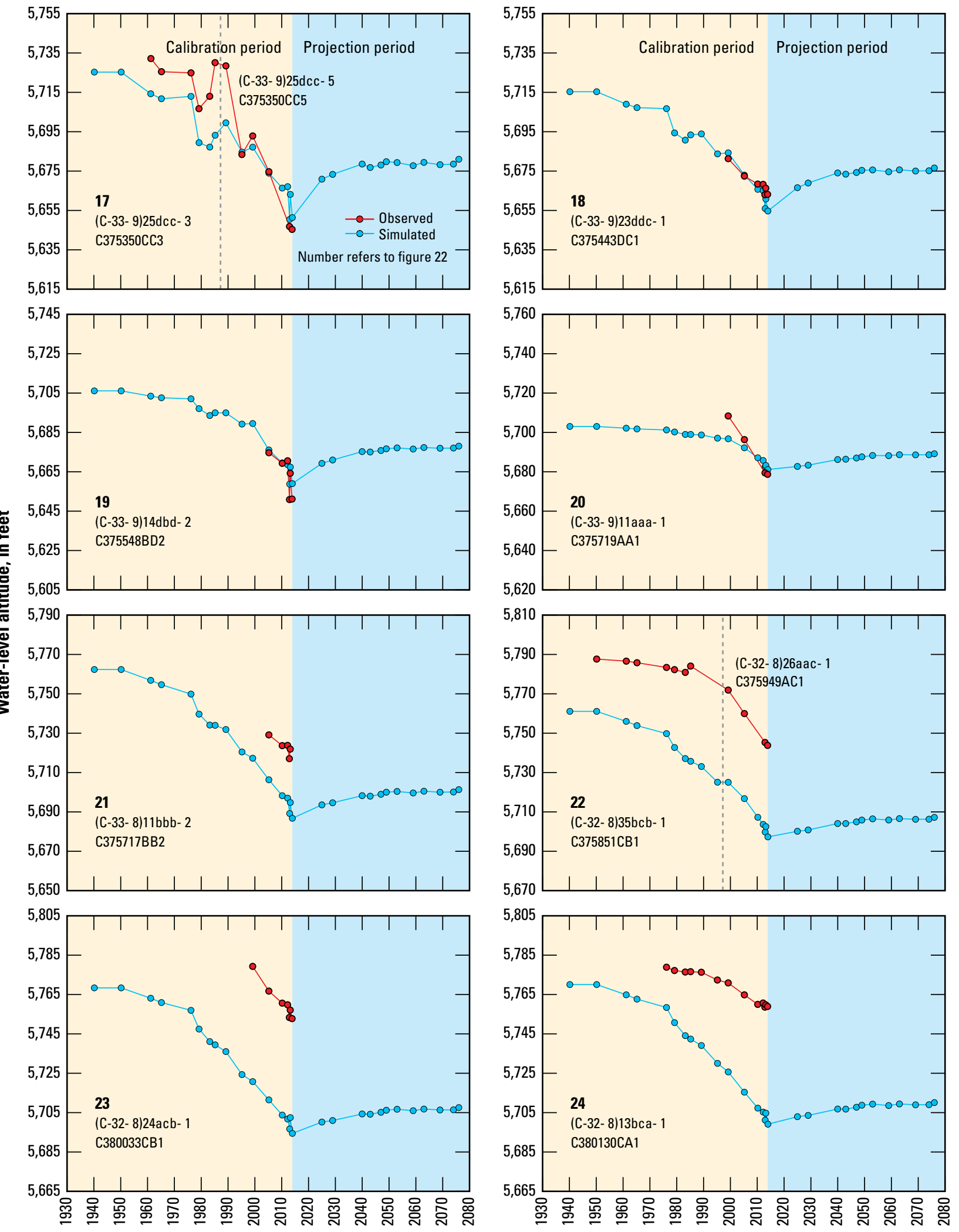

Replacement observation wells indicated by dashed vertical line and second well identification

Figure 24. Water-level altitudes simulated at the end of each stress period of the GBCAAS v. 3.0 groundwater model and measured water-level altitudes at selected wells during 1940 to 2013, Parowan Valley, Utah.-Continued 


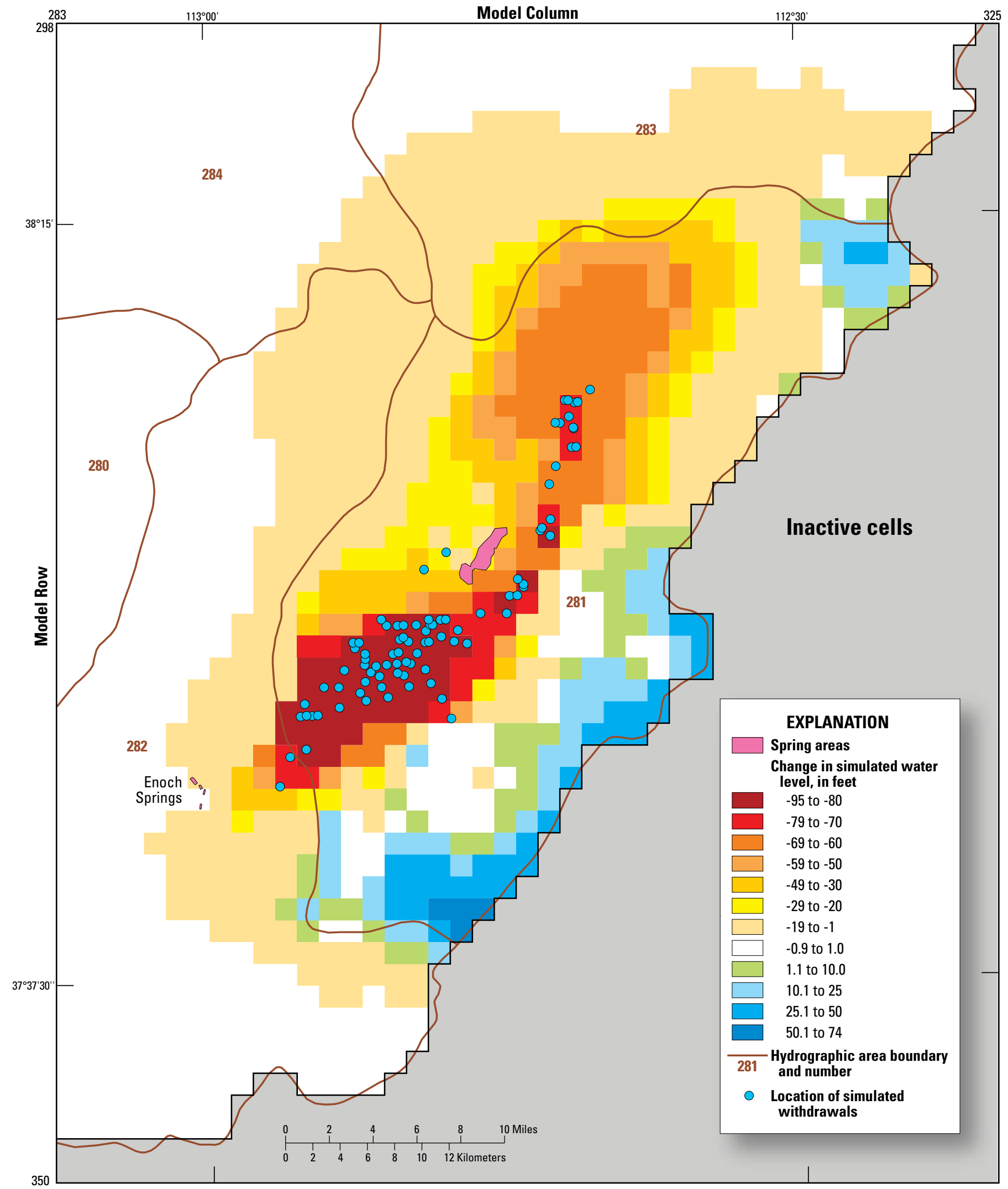

Figure 25. Simulated water-level change in layer 1 from the steady-state period to the end of stress period 16 of the GBCAAS v. 3.0 groundwater model, Parowan Valley, Utah. 


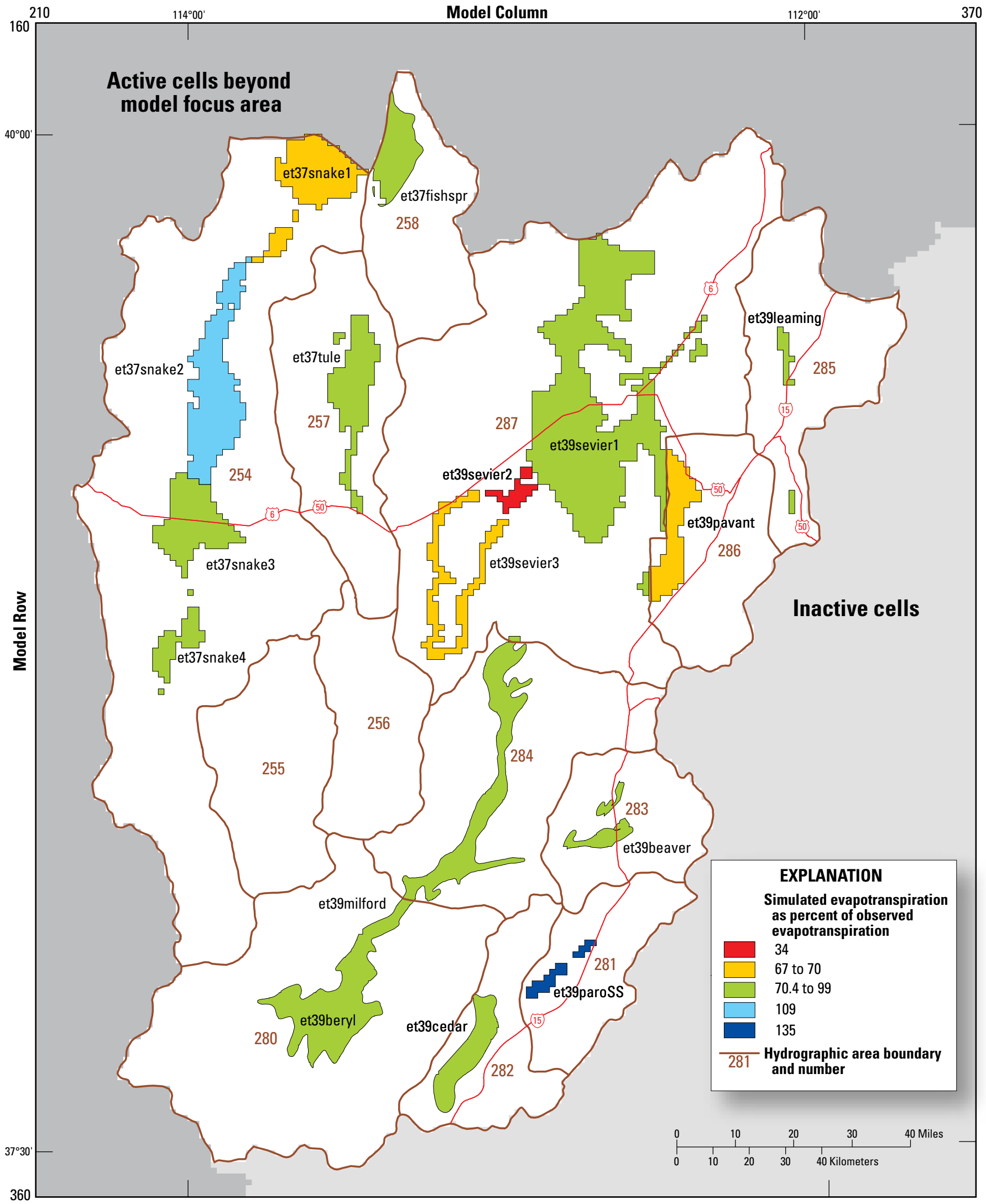

Figure 26. Steady-state evapotranspiration simulated by the GBCAAS v. 3.0 groundwater model, as percent of observed evapotranspiration, model focus area, Utah and Nevada. 


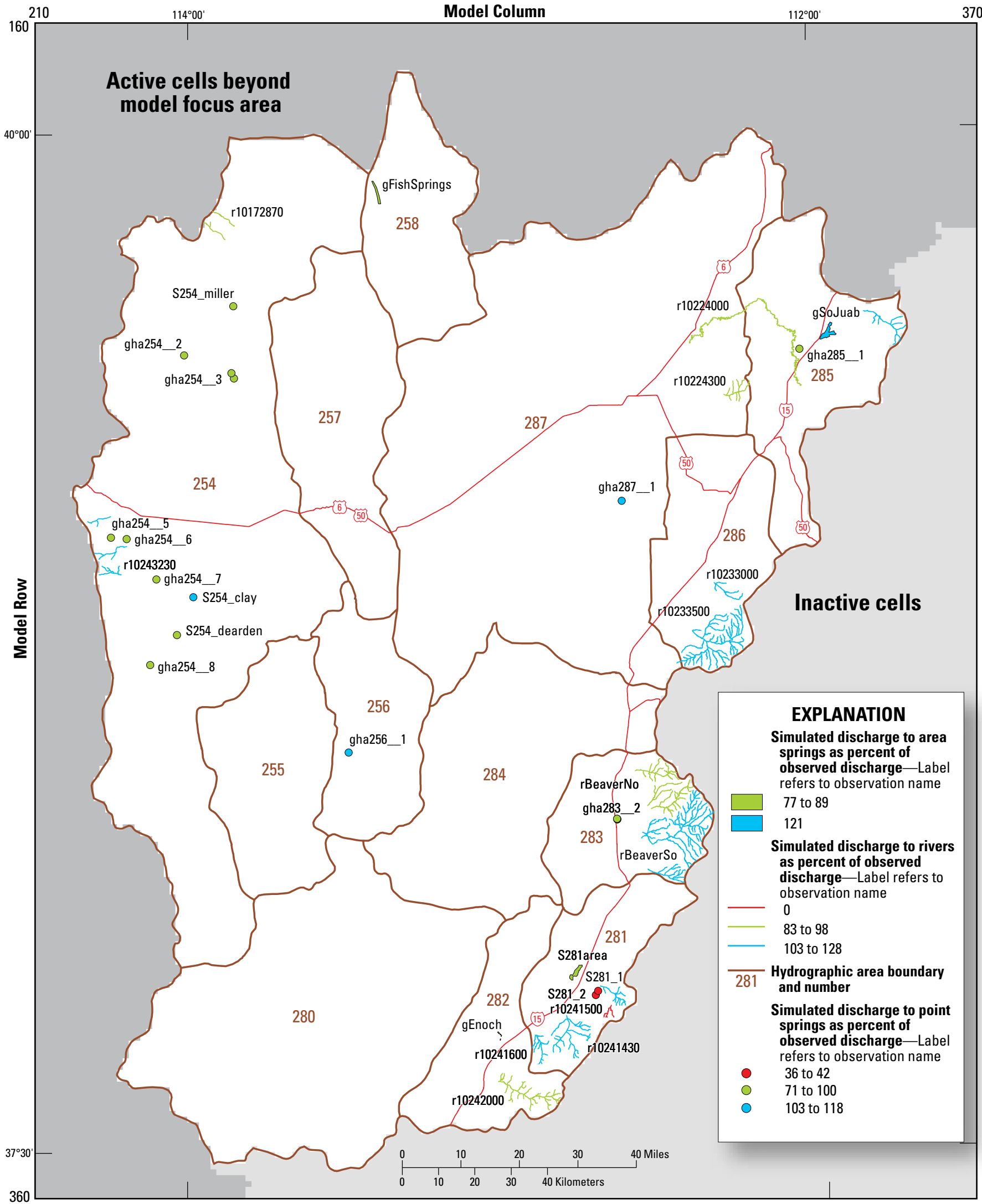

Figure 27. Steady-state simulated discharge to springs and rivers simulated by the GBCAAS v. 3.0 groundwater model, as percent of observed discharge, model focus area, Utah and Nevada. 


\section{Model Results}

In addition to indications of model adequacy, the model can be used to gain insights into the groundwater system that were not included in evaluating the accuracy of the calibration (Brooks and others, 2014, p. 71). These include simulated transmissivity, simulated groundwater budgets, and subsurface interflow between HAs.

\section{Transmissivity}

Total transmissivity of the simulated thickness controls horizontal flow, which often is more important than vertical flow at the regional scale (Haitjema, 2003). The program HUFPrint (Banta and Provost, 2008) was used to calculate the hydraulic conductivity of each model layer. This was multiplied by the thickness of the layer to determine the transmissivity of each layer, which were summed to determine total transmissivity (fig. 28). Brooks and others (2014, p. 71-73) described comparisons between simulated transmissivity and geology, and that analysis is not repeated here.

Simulated transmissivity in GBCAAS v. 3.0 (fig. 28) shows the same general trends as in previous versions (Brooks and others, 2014, fig. 40), but an analysis of the ratio of transmissivity in GBCAAS v. 3.0 to the transmissivity in previous versions (fig. 29) showed areas that were changed for recalibration to new observations. Reasons for transmissivity changes are explained as follows:

1. Transmissivity was reduced between Snake Valley (HA 254) and Pine (HA 255) and Wah Wah (HA 256) Valleys. This reduced simulated water levels in the northern part of Wah Wah Valley and southern parts of Tule Valley (HA 257) and Sevier Desert (HA 287) and reduced simulated ETg in the southern part of Sevier Desert. The simulated equivalents in those areas more closely match observed values (figs. 20 and 26) than they did by using the parameter values from previous versions (figs. 15 and 16).

2. Transmissivity was similar or reduced between Pine and Wah Wah Valleys (HAs 255 and 256), except in a small area where transmissivity was greatly increased. The reductions in transmissivity around Wah Wah Springs (gha256_1) allowed transmissivity to be increased in areas north of the springs and have the simulated equivalent match the observed value of discharge at Wah Wah Springs (table 1-6).

3. Transmissivity and recharge were reduced in southern Snake Valley. This reduced simulated ETg in southern Snake Valley. The simulated equivalent for observation et 37 snake4 (fig. 26) more closely matches the observed discharge than by using the parameter values from previous versions (fig. 16).
4. Transmissivity was reduced in eastern Snake Valley. This increased simulated ETg in central Snake Valley. The simulated equivalent for observation et 37 snake 3 (fig. 26) more closely matches the observed value than by using the parameter values from previous versions (fig. 16).

5. Transmissivity was increased in Tule Valley (HA 257). This reduced simulated ETg and water levels in Tule Valley (fig. 19). The simulated equivalents for observation et37tule (fig. 26) and water-level observations in that area (fig. 20) more closely match observed values than by using the parameter values from previous versions (figs. 15 and 16).

6. Transmissivity was reduced in parts of Sevier Desert (HA 287). This increased simulated ETg as observation et39sevier1 (fig. 26) and decreased water levels on the west side of Sevier Lake (fig. 19). The simulated equivalents for observation et39sevier1 (fig. 26) and water-level observations in that area (fig. 20) more closely match the observed values than by using parameter values from previous versions (figs. 15 and 16).

7. Transmissivity was increased in Parowan Valley, mostly as a result of having more calibration data than previous versions (figs. 15 and 20).

8. Other changes were minor and related to parameter values, changes in recharge, or possible changes in model thickness.

\section{Simulated Groundwater Budgets}

The simulated groundwater budgets presented in this report (table 8 ) were determined by the model using the calibrated parameters. Total recharge and discharge simulated in the model focus area are about 88 percent of the conceptual recharge. Total discharge simulated in the model focus area is about 102 percent of the conceptual discharge. The model budget is more balanced than the conceptual budget, and indicates little net groundwater flow into or out of the model focus area. Uncertainty in the budgets is not presented explicitly; uncertainty in the parameters (fig. 18; appendix 2), however, provides an approximation of the uncertainty in the water budgets. For example, the uncertainty in recharge parameters (table 2-2) provides one measure of the uncertainty in the budgets, but uncertainty in other parameters also affects the uncertainty of the simulated budgets.

\section{Pine and Wah Wah Valleys}

Simulated recharge in Pine (HA 255) and Wah Wah (HA 256) Valleys is substantially less in GBCAAS v. 3.0 (table 8) than in previous model versions and the GBCAAS conceptual 


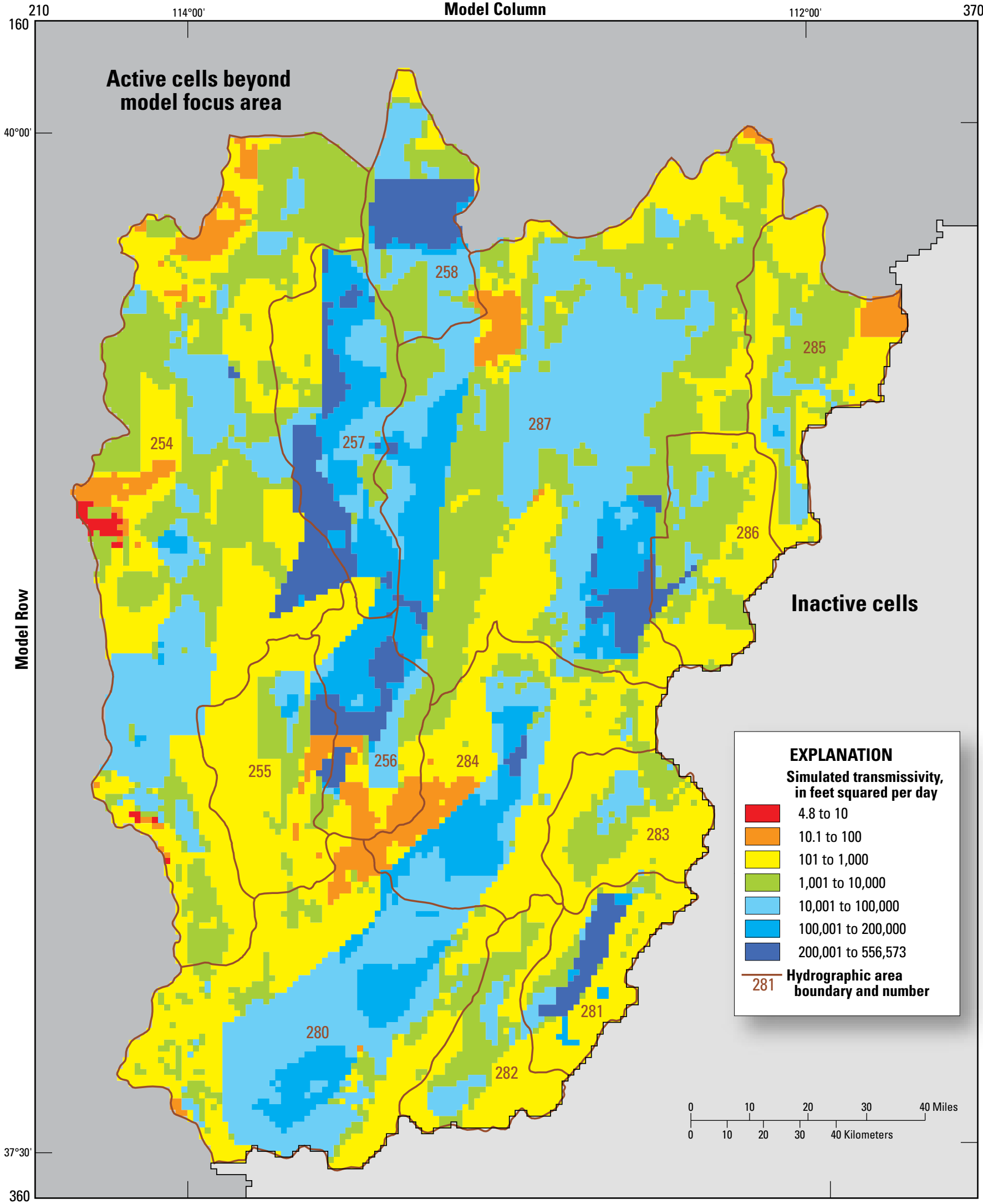

Figure 28. Simulated transmissivity in the GBCAAS v. 3.0 groundwater model, model focus area, Utah and Nevada. 


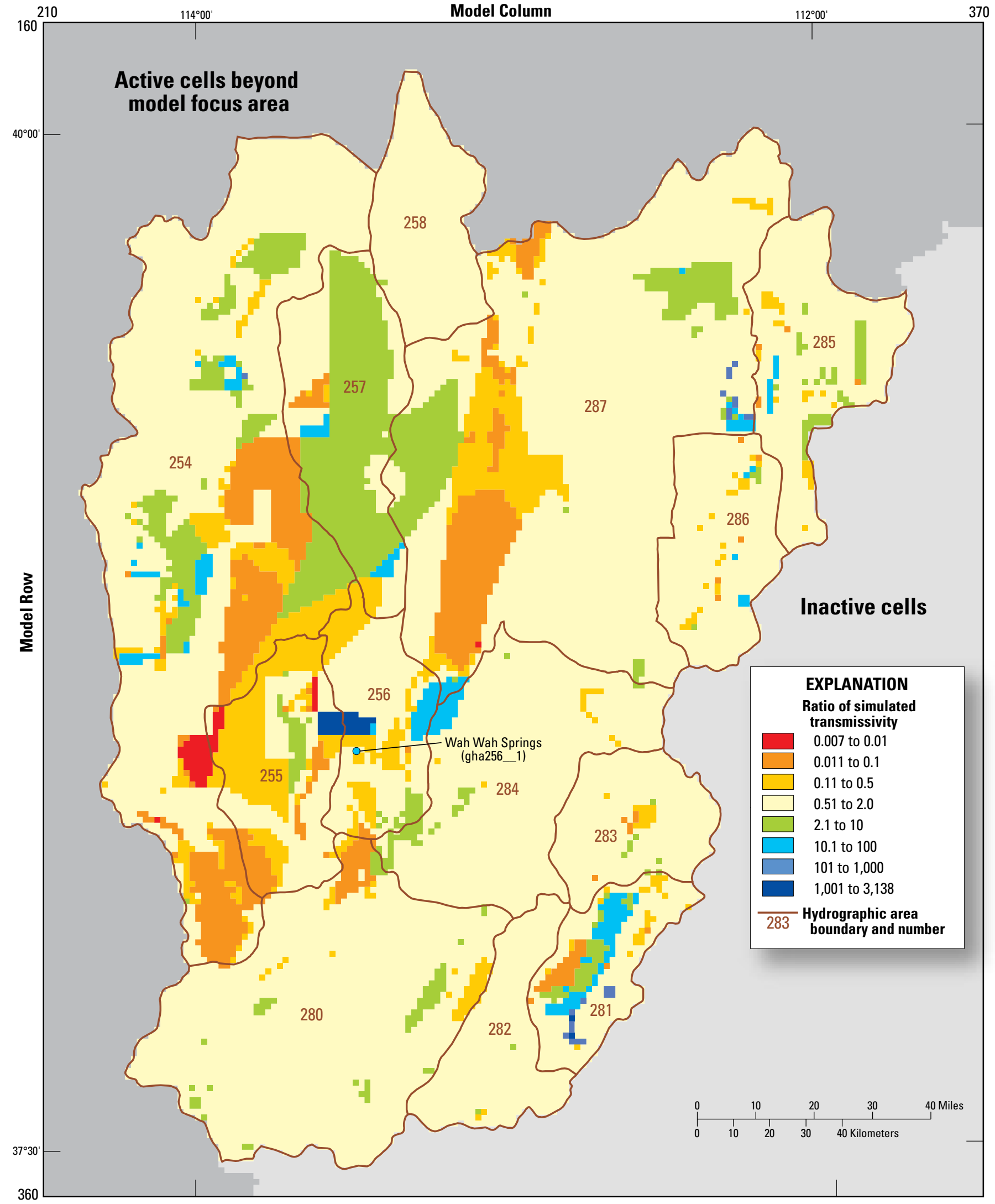

Figure 29. Simulated transmissivity in the GBCAAS v 3.0 groundwater model as a ratio of simulated transmissivity in the GBCAAS v. 2.0 groundwater model, model focus area, Utah and Nevada. 


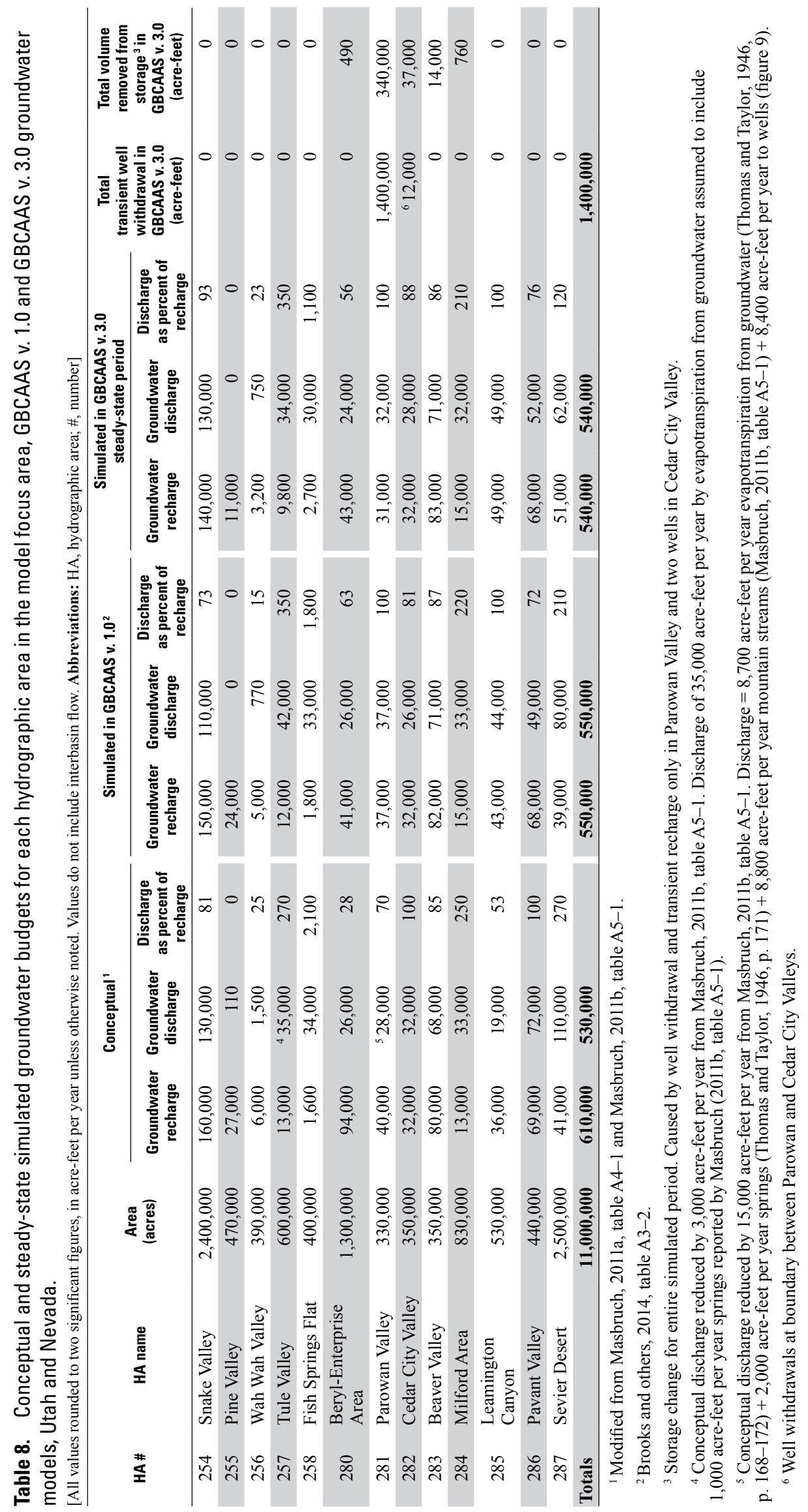


model (Masbruch, 2011a, table A4-1). During model calibration, recharge was reduced to cause simulated water levels on the west side of Sevier Lake (fig. 19) to more closely match recent observed water levels. This reduction in recharge follows a trend in which simulated recharge was reduced as water-level data became available in parts of the study area where observations were previously absent (fig. 30).

The simulated recharge does not include all recharge in the two HAs. Pine and Wah Wah Valleys have areas of groundwater discharge to springs and ETg in the mountains (Philip Gardner, U.S. Geological Survey, written commun., July 21, 2016). With the exception of Wah Wah Springs (gha256_1 on fig. 27), these springs and ETg were not simulated, and the model calibration did not include recharge to supply those areas. Simulated recharge is considered representative of the amount of water that stays in the groundwater system as it moves toward the valleys, toward Wah Wah Springs, or northward. The springs and ETg areas in the mountains typically are small, and their altitudes indicate that the hydraulic conductivity of rock in the mountains is small, creating a large gradient between the springs and the valley. At the spatial resolution of the model grid, it was not possible to simulate discharge to the springs without also causing simulated water levels in much of the mountain area to be substantially above land surface. At a 1-mi ${ }^{2}$ grid size, the land surface and the recharge are too general for adequate simulation; a more refined model grid may improve simulation of the mountains around Pine and Wah Wah Valleys and of the effects of withdrawals on mountain springs.

Pine (HA 255) and Wah Wah (HA 256) Valleys are part of a larger groundwater flow system (Gardner and others, 2011; Heilweil and Brooks, 2011). The valleys, however, have less simulated inflow from and outflow to other hydrographic areas than in previous model versions (table 9). This was caused both by more refined estimates and simulation of ETg in Sevier Desert (HA 287) and by more refined simulation of ETg in Snake Valley (HA 254). The potentiometric-surface contours (fig. 20) indicate that most of the flow from Snake Valley to Pine and Wah Wah Valleys and from Pine Valley to Wah Wah Valley occurs in the northern parts of Pine and Wah Wah Valleys. The contours also indicate that the HFB in Tule Valley (HA 257; fig. 12) creates an area of little connection (steep gradient) between Snake Valley (HA 254) and Tule Valley (HA 257); most of the flow from Snake Valley to Tule Valley probably occurs in the northern part of Tule Valley.

\section{Effects of Groundwater Development}

The valleys have little natural discharge and the effects of groundwater development in these valleys are independent of the amount of water recharging in and flowing through the valleys. Alley and others (1999, p. 15) stated that predevelopment water budgets are of limited value in determining the amount of groundwater that can be withdrawn on a sustained basis. Bredehoeft and others (1982, p. 55) also stated that a water budget is of little use in determining magnitude of development and further stated that the magnitude of sustained groundwater withdrawals generally depends on how much natural discharge can be captured. Groundwater withdrawals in Pine and Wah Wah Valleys will decrease groundwater storage (causing drawdown) until the rate of discharge in surrounding areas (mostly Tule Valley, Snake Valley, and Sevier Desert) and mountain springs around the two valleys (including Wah Wah Springs) is reduced by the rate of withdrawal. If the withdrawals are so large that a new equilibrium cannot be reached, water will continue to be removed from storage (Alley and others, 1999, p. 22).

The response of the groundwater system to withdrawals in Pine and Wah Wah Valleys depends on aquifer transmissivity, storage coefficient, boundary conditions, and the location of development within the system (Bredehoeft and others, 1982, p. 52). The transmissivity of the calibrated model in and around the valleys is dependent on the simulated recharge; this relationship means that, indirectly, simulated effects of groundwater discharge are dependent on the simulated recharge. Alley and others $(1999$, p. 70$)$ stated that although predictions based on model simulations are imprecise, they may represent the best decision-making information at a given time. Because GBCAAS v. 3.0 matches recent water-level observations and refined estimates of ETg better than previous versions of the model (figs. 15, 16, 20, and 26), it is likely to provide more accurate analyses of the effects of groundwater development. In addition, because GBCAAS v. 3.0 is a transient model, timing of effects (although with uncalibrated storage properties) can be analyzed.

\section{Parowan Valley}

The conceptual (Marston, 2017) and simulated steady-state groundwater budgets for Parowan Valley (HA 281) are smaller than the GBCAAS conceptual budget (Masbruch, 2011a, b) and the previously simulated budget (table 8) for Parowan Valley because the previous estimate of ETg was considered too large (see the "Need for Recalibration" section and table 2). The large estimate of ETg required adjustments to BCM recharge in previous versions to more closely match the ETg estimate. The GBCAAS conceptual recharge multiplied the BCM estimate by 1.37 (Masbruch and others, 2011, fig. D-8). Previous model versions multiplied the BCM estimate by 1.21 (Brooks and others, 2014, table A4-4, parameter rch281). In GBCAAS v. 3.0, steady-state recharge in Parowan Valley is described by three recharge parameters ( $\mathrm{rch} 281, \mathrm{rch} 2812$, and rchirr281B in table 2-2), which multiply BCM estimates by $1.08,0.99$, and 0.92 , respectively. Parameters rch281 and rch2812 mostly represent recharge in the mountains around Parowan Valley, and parameter rchirr281B represents recharge in the valley. The zones and parameter values were determined during calibration.

The conceptual and simulated groundwater budgets for Parowan Valley from November 2012 to November 2013 (table 10) are similar, indicating the model provides a good representation of the transient groundwater system in Parowan Valley. The model does not simulate enough discharge to 


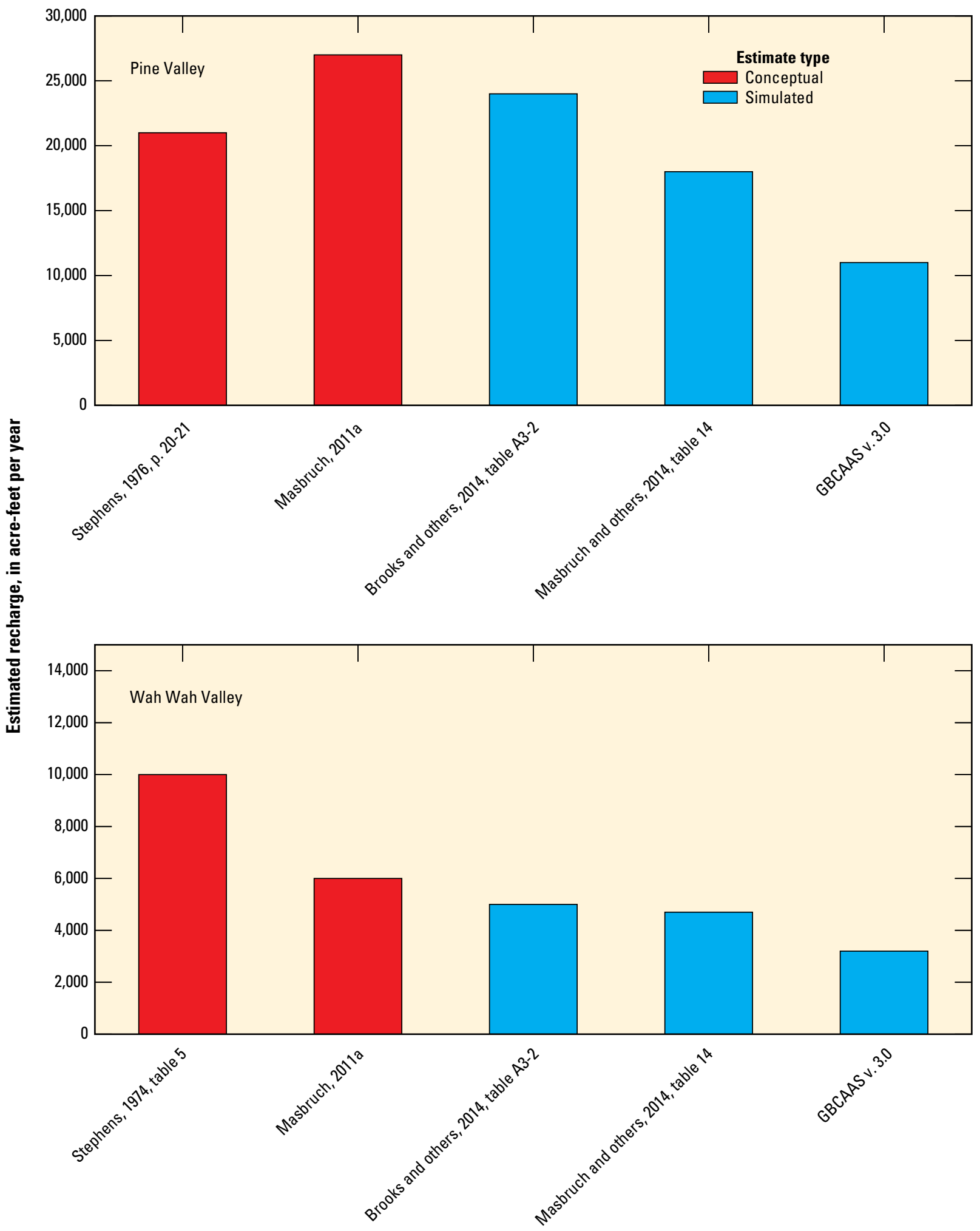

Figure 30. Estimates of recharge, Pine and Wah Wah Valleys, Utah. 
Table 9. Comparison of interbasin flow simulated in the GBCAAS v. 1.0 and GBCAAS v. 3.0 groundwater models, model focus area, Utah and Nevada.

[All flows in acre-feet per year, rounded to two significant figures. Negative value indicates flow is in opposite direction as listed. Lower limit and upper limit: simultaneous 95-percent confidence intervals of the predictions calculated by UCODE_2014 (Poeter and others, 2008)]

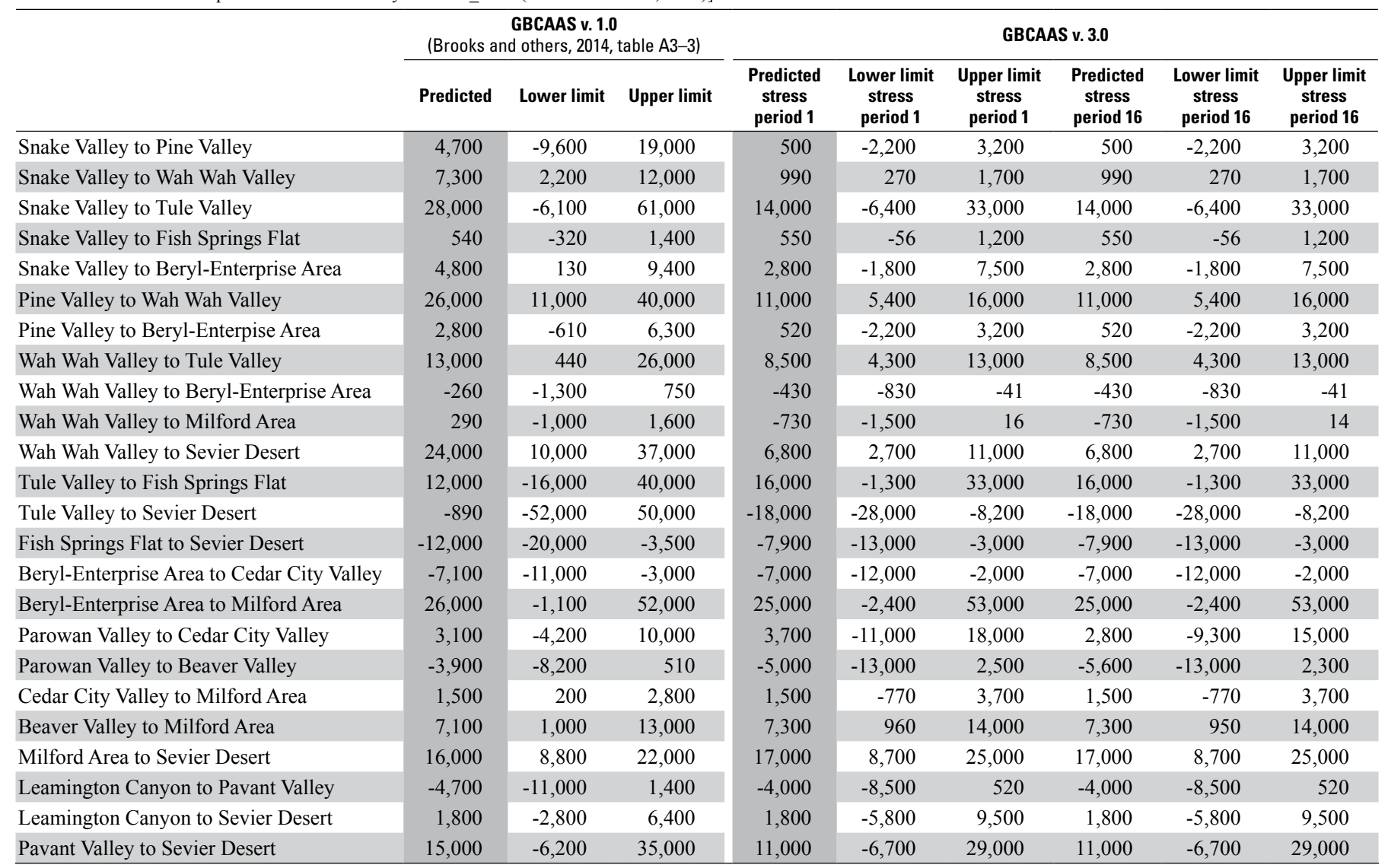

Table 10. Conceptual groundwater budget for November 2012 to October 2013 and simulated groundwater budget for stress periods 15 and 16 (December 2012-November 2013) of the GBCAAS v. 3.0 groundwater model, Parowan Valley, Utah.

[All values in acre-feet, rounded. - , not estimated]

\begin{tabular}{|c|c|c|}
\hline \multicolumn{3}{|l|}{ Recharge } \\
\hline & Conceptual $^{1}$ & Simulated \\
\hline Precipitation & 11,800 & 17400 \\
\hline Stream seepage and irrigation return flows & 5,000 & $11,+00$ \\
\hline Subsurface flow from Beaver Valley & - & 5,600 \\
\hline Total & 16,800 & 23,000 \\
\hline \multicolumn{3}{|c|}{ Discharge } \\
\hline Wells $^{2}$ & 32,000 & 35,100 \\
\hline Evapotranspiration & 200 & 0 \\
\hline Streams and springs & 13,000 & 10,600 \\
\hline Subsurface flow to Cedar City Valley & - & 2,800 \\
\hline Total & 45,000 & 48,000 \\
\hline Change in storage & $-28,400$ & $-24,100$ \\
\hline
\end{tabular}

${ }^{1}$ Marston, 2017, table 4.

${ }^{2}$ Includes withdrawal from two wells in Cedar City Valley (HA 282) near Parowan Valley (fig. 8). springs in the mountains (S281_1 and S281_2 on fig. 27; table 1-6), which is reflected in the 2,400 acre-ft/yr difference between conceptual and simulated discharge to streams and springs (table 10). The difference between conceptual and simulated change in storage is partly because of the difference in springs and partly because simulated inflow from Beaver Valley (HA 283) is greater than simulated outflow to Cedar City Valley (HA 282).

The changes in the simulated budget during the transient simulation (table 11; fig. 31) provide the following insights about the groundwater system:

1. Withdrawals from 1950 to 1975 did not create major changes in the groundwater system from the steadystate conditions assumed to exist from 1940 to 1950 .

a. Some water was released from storage, causing water-level declines, and discharge to ETg decreased slightly.

b. At the 1950 to 1975 rate of withdrawal (average of about 12,000 acre-ft/yr), the system eventually may have reached new steady-state conditions with less discharge to ETg than previously, but with relatively stable groundwater levels. 
2. The increase in the average annual withdrawals to about 28,000 acre-ft/yr starting in 1976 caused major changes in the groundwater system.

a. ETg decreased and became negligible (observations et39paroSS and et39paro16 in table 1-6). The simulated ETg of zero at the end of stress period 16 closely matches the small amount of reported ETg in Parowan Valley in 2013 (table 10). Both indicate that ETg has been almost completely captured by groundwater withdrawals.

b. Discharge to springs in the valley (S281area2 on fig. 27) decreased and became zero (observations S281 area and S281area in table 1-6). The simulated discharge is zero at the end of stress period 16 (table 1-6). Marston (2017, p. 28) reported no observed discharge from these springs in 2013. Spring discharge in the valley has been completely captured by groundwater withdrawals.

c. In the simulation, more water is removed from storage during most stress periods after 1976 than during most stress periods before 1976 (fig. 31). This is consistent with increased rate of water-level decline after 1976 (fig. 24)

d. Minor contributions (negative reduction) to storage are simulated when recharge is about 1.4 times the average recharge (figs. 6 and 31).

e. Major contributions to storage are simulated only when recharge exceeds 1.8 times the average recharge.

f. At the post-1976 rate of withdrawal (average of 28,000 acre-ft/yr), natural discharge in the valley has been almost completely captured (Marston, 2017, p. 28). Because natural discharge in the valley has been captured, the post1976 rate of withdrawal with average recharge will cause groundwater levels to continue declining until discharge from streams and springs in the mountains or discharge in other valleys is reduced by the rate of withdrawal.

\section{Interbasin Flow}

Conceptual estimates have not been determined for interbasin flow for November 2012 to October 2013 and have never been determined from Beaver Valley (HA 283) to Parowan Valley (HA 281). In the model, the flow from Beaver Valley to Parowan Valley indicates that the groundwater divide is north of the surface-water divide between the valleys, but simulated water levels (fig. 20) indicate that a groundwater divide does exist. Simulated flow from Beaver Valley to Parowan Valley increases slightly from 1940 to 2013 (table 11), which may indicate a slight northward shift in the groundwater divide.

Simulated water levels (fig. 20) indicate no groundwater divide between Parowan Valley (HA 281) and Cedar City Valley (HA 282) at the southern end of Parowan Valley. This is consistent with conceptual groundwater flow in the area (Marston, 2017, fig. 9). Thomas and Taylor (1946, p. 170) estimated about 5,000 acre-ft/yr of flow from Parowan Valley to Cedar City Valley. Brooks and Mason (2005, table 2) estimated from 2,000 to 5,000 acre-ft/yr during pre-development conditions and 2,000 acre-ft/yr in 2000. The model indicates variation in the amount of flow from Parowan Valley to Cedar City Valley depending on other stresses, but also indicates a general reduction in flow from 1940 to 2013 (table 11).

Discharge to Enoch Springs in Cedar City Valley (gEnoch on fig. 27) ceased before 1978 because of declining groundwater levels (Bjorklund and others, 1978, p. 41); the principal cause of the declining levels has been the withdrawal of water by wells (Bjorklund and others, 1978, p. 33). Discharge to Enoch Springs in the steady-state model period is a model observation; discharge to Enoch Springs in other model periods was not included as observations because withdrawals in Cedar City Valley are not simulated, and they probably influence discharge to the springs. Simulated withdrawals in Parowan Valley decrease the simulated flow from Parowan Valley to Cedar City Valley (tables 9 and 11) and also decrease simulated groundwater levels near Enoch Springs (fig. 25). Examination of cell-by-cell discharge in the model files (Brooks, 2017) showed a decrease in discharge at the springs of $970 \mathrm{acre}-\mathrm{ft} / \mathrm{yr}$ from the steady-state period to the end of stress period 16. Brooks and Mason (2005, table 15 and page 94) reported that their model of Cedar City Valley did not match the observed reduction in discharge to Enoch Springs. The mismatch was about 1,000 acre-ft/yr. Simulating withdrawals in both valleys may cause simulated discharge to be reduced to close to the observed value of zero. 
Table 11. Simulated groundwater budget for each calibration stress period of the GBCAAS v. 3.0 groundwater model, Parowan Valley, Utah.

[All amounts in acre-feet per year, except stress periods 14 to 16, which are in acre-feet. All amounts rounded to three significant figures]

\begin{tabular}{|c|c|c|c|c|c|c|c|c|c|c|}
\hline \multirow[b]{2}{*}{$\begin{array}{l}\text { Stress } \\
\text { period }\end{array}$} & \multirow[b]{2}{*}{ Dates simulated } & \multicolumn{3}{|c|}{ Simulated inflow } & \multicolumn{6}{|c|}{ Simulated outflow } \\
\hline & & Recharge & $\begin{array}{c}\text { Storage } \\
\text { removed from } \\
\text { aquifer }\end{array}$ & $\begin{array}{l}\text { Inflow from } \\
\text { Beaver Valley }\end{array}$ & Wells $^{1}$ & $\begin{array}{c}\text { Evapotrans- } \\
\text { piration of } \\
\text { groundwater }\end{array}$ & Rivers & Springs & $\begin{array}{c}\text { Storage } \\
\text { added to } \\
\text { aquifer }\end{array}$ & $\begin{array}{c}\text { Outflow to } \\
\text { Cedar City } \\
\text { Valley }\end{array}$ \\
\hline 1 & March 1940 to February 1950 & 31,100 & 0 & 5,040 & 8,430 & 11,700 & 8,950 & 3,290 & 0 & 3,730 \\
\hline 2 & March 1950 to February 1961 & 24,200 & 6,920 & 5,260 & 11,800 & 10,400 & 8,290 & 2,660 & 0 & 3,220 \\
\hline 3 & March 1961 to February 1965 & 22,700 & 7,920 & 5,340 & 12,600 & 9,910 & 8,060 & 2,430 & 0 & 2,950 \\
\hline 4 & March 1965 to February 1976 & 28,500 & 2,310 & 5,330 & 13,200 & 9,210 & 8,160 & 2,320 & 199 & 3,030 \\
\hline 5 & March 1976 to February 1979 & 22,600 & 18,500 & 5,430 & 29,900 & 4,430 & 7,970 & 1,860 & 0 & 2,290 \\
\hline 6 & March 1979 to February 1983 & 39,100 & 6,260 & 5,290 & 25,200 & 3,410 & 8,690 & 2,060 & 8,570 & 2,730 \\
\hline 7 & March 1983 to February 1985 & 52,000 & 2,090 & 5,120 & 20,200 & 3,380 & 9,420 & 2,380 & 20,400 & 3,370 \\
\hline 8 & March 1985 to February 1989 & 30,600 & 3,820 & 5,230 & 20,700 & 3,140 & 8,980 & 2,030 & 1,500 & 3,280 \\
\hline 9 & March 1989 to February 1995 & 22,600 & 13,500 & 5,480 & 27,200 & 1,720 & 8,450 & 1,650 & 24 & 2,500 \\
\hline 10 & March 1995 to February 1999 & 39,100 & 2,960 & 5,340 & 24,400 & 1,400 & 9,190 & 1,970 & 7,510 & 2,880 \\
\hline 11 & March 1999 to February 2005 & 24,800 & 12,400 & 5,560 & 29,900 & 482 & 8,600 & 1,610 & 21 & 2,210 \\
\hline 12 & March 2005 to February 2010 & 30,300 & 8,360 & 5,590 & 31,200 & 169 & 8,750 & 1,700 & 820 & 2,730 \\
\hline 13 & March 2010 to February 2012 & 57,800 & 3,480 & 5,350 & 30,500 & 87 & 10,000 & 2,250 & 21,600 & 3,450 \\
\hline 14 & March 2012 to November 2012 & 19,700 & 29,000 & 4,100 & 43,300 & 0 & 6,970 & 1,360 & 691 & 2,390 \\
\hline 15 & December 2012 to February 2013 & 350 & 7,750 & 1,360 & 0 & 0 & 2,140 & 359 & 6,260 & 699 \\
\hline 16 & March 2013 to November 2013 & 17,000 & 22,900 & 4,190 & 35,100 & 0 & 6,780 & 1,270 & 209 & 2,130 \\
\hline
\end{tabular}

${ }^{1}$ Includes two wells in Cedar City Valley near boundary (see figure 8). 

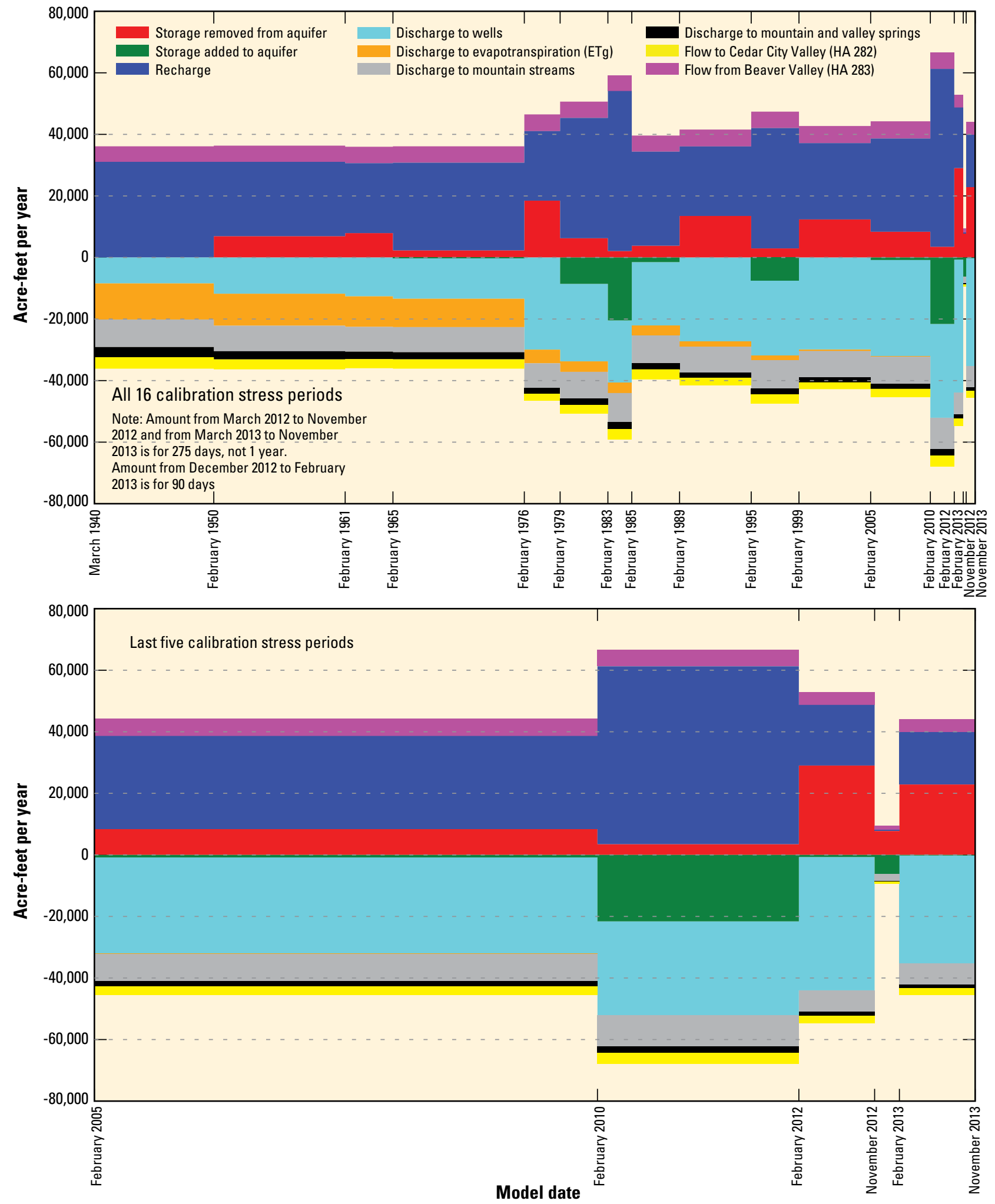

Figure 31. Groundwater-budget components for the calibration stress periods of the GBCAAS v. 3.0 groundwater model, Parowan Valley, Utah, 1940 to 2013. 


\section{Model Projection}

The model was used to estimate the reduction of withdrawals in Parowan Valley (HA 281) needed to stabilize groundwater levels in the valley. The model was also used to estimate the effects of recently approved groundwater withdrawals in Pine (HA 255) and Wah Wah (HA 256) Valleys of 15,000 and 6,500 acre-ft/yr, respectively (Jim Reese, Utah Division of Water Rights, written commun., July 8, 2016). The analyses were combined into 1 simulation with 14 projection stress periods (table 1). The projection simulation uses the ending heads from the calibration simulation as starting heads. The first 12 projection stress periods repeat the length and recharge of calibration stress periods 2 to 13 to provide a method of varying the recharge in Parowan Valley in a pattern similar to that of historical variations (fig. 6). The last two projection stress periods use the same recharge as the initial steady-state period and provide enough time for the model to approach new steady-state conditions with the Pine and Wah Wah permitted withdrawal rates.

Reducing simulated withdrawals from 35,000 to 22,000 acre-ft/yr in Parowan Valley (and two wells in Cedar City Valley) causes simulated levels to rise for the first three projection stress periods (26 years) and then to stabilize (fig. 24). The water levels rise even though recharge for the first four projection stress periods is less than the 1940 to 2006 average (fig. 6). The simulated withdrawal rate needed to stabilize water levels is similar to the simulated amount of discharge in the steady-state stress period of the model, which is 13,200 acre-ft/yr to ETg and springs (observations et39paroSS and S281area in table 1-6) plus groundwater pumping of $8,400 \mathrm{acre}-\mathrm{ft} / \mathrm{yr}$. This is reasonable, because groundwater levels were relatively stable prior to 1950 (Bjorklund and others, 1978, fig. 17). The simulated annual rate of water removed from storage fluctuates around zero, with water added to storage during periods of above-average recharge and removed from storage during periods of below-average recharge (fig. 32).

Simulating 15,000 and 6,500 acre-ft/yr of proposed withdrawals in Pine and Wah Wah Valleys, respectively, causes large drawdowns near the withdrawal wells within 62 years and ultimately causes water-level declines of more than $1,900 \mathrm{ft}$ near the withdrawals and of more than $5 \mathrm{ft}$ in an area of about 10,500 $\mathrm{mi}^{2}$ (fig. 33). The drawdown expands across the region because no natural discharge occurs nearby that can be captured. The drawdown continues until water levels at distant discharge areas are reduced enough to capture discharge equal to the withdrawal rate. After 5,000 years, the system approaches a new steady-state condition (fig. 32), with less than 1 percent (112 acre-ft/yr) of the withdrawal rate still supplied by a decrease in storage. During the first 62 years of the projection, 1,333,000 acre-feet of water is withdrawn by the wells in Pine and Wah Wah Valleys. An average of about 21,000 acre-ft/yr of water is removed from storage during the first 62 years of the projection (fig. 32), totaling about 1,300,000 acre-feet of water removed from storage.
An average of about 600 acre-ft/yr of water is captured from natural discharge during the first 62 years, totaling only 37,000 acre- $f t$ reduction in natural discharge. Even if withdrawals were ceased after 62 years, natural discharge would eventually be reduced by an additional 1,300,000 acre-feet $(1,333,000$ minus 37,000 acre-ft, rounded) because the total amount of decrease in natural discharge is equal to the total amount withdrawn. With any groundwater withdrawal, depletion of natural discharge can reach a maximum after pumping stops, and the time from cessation of pumping until full recovery can be longer than the time that the well was pumped (Barlow and Leake, 2012, p. 43).

The timing of and long-term drawdown and capture are dependent on the location and amount of natural discharge than can be captured. Other than Wah Wah Springs (observation gha256 _ 1), natural discharge is far enough away from the withdrawals that discharge to individual areas is not reduced by more than 5 percent for more than 62 years (table 12). Because the projection stress periods, outside of Parowan Valley, start with pre-development steady-state conditions, the projection simulates capture of groundwater discharge that, in the real system, has already been captured by withdrawals that are not simulated (especially in the Beryl-Enterprise Area, HA 280). As a result, the drawdown presented in this report may underestimate the amount and extent of drawdown possible from the withdrawals in Pine and Wah Wah Valleys. Simulating all model layers as confined is another model limitation because transmissivity is not reduced with declining water levels; this could also result in the model underestimating the amount and extent of drawdown.

Simulated effects (recovery, drawdown, and capture of natural discharge) also are dependent on aquifer transmissivity and storage properties. The simulated ultimate (long-term steady-state) drawdown and capture are based on simulated aquifer transmissivity, which is considered reasonably calibrated throughout the model. Simulated storage properties in Parowan Valley are considered adequately calibrated, and the simulated timing of the water-level recovery is likely a reasonable estimate of actual timing if withdrawals are reduced in Parowan Valley. Simulated storage properties outside of Parowan Valley are set the same as the Parowan Valley properties and are not considered calibrated. The timing of drawdown and capture outside of Parowan Valley are a representation of what would happen if those storage parameters are correct. The values of specific yield of 0.07 for basin fill and 0.01 for rock and the value of specific storage for all units of $1.2 \times 10^{-7}$ (table 2-9) are within the range of calibrated parameters in the transient numerical model of the Death Valley regional groundwater flow system (Faunt and others, 2010, table F-13). Sweetkind and others (2011a, p. 16) reported that the units in the Death Valley regional groundwater system can be used to represent the GBCAAS study area. 


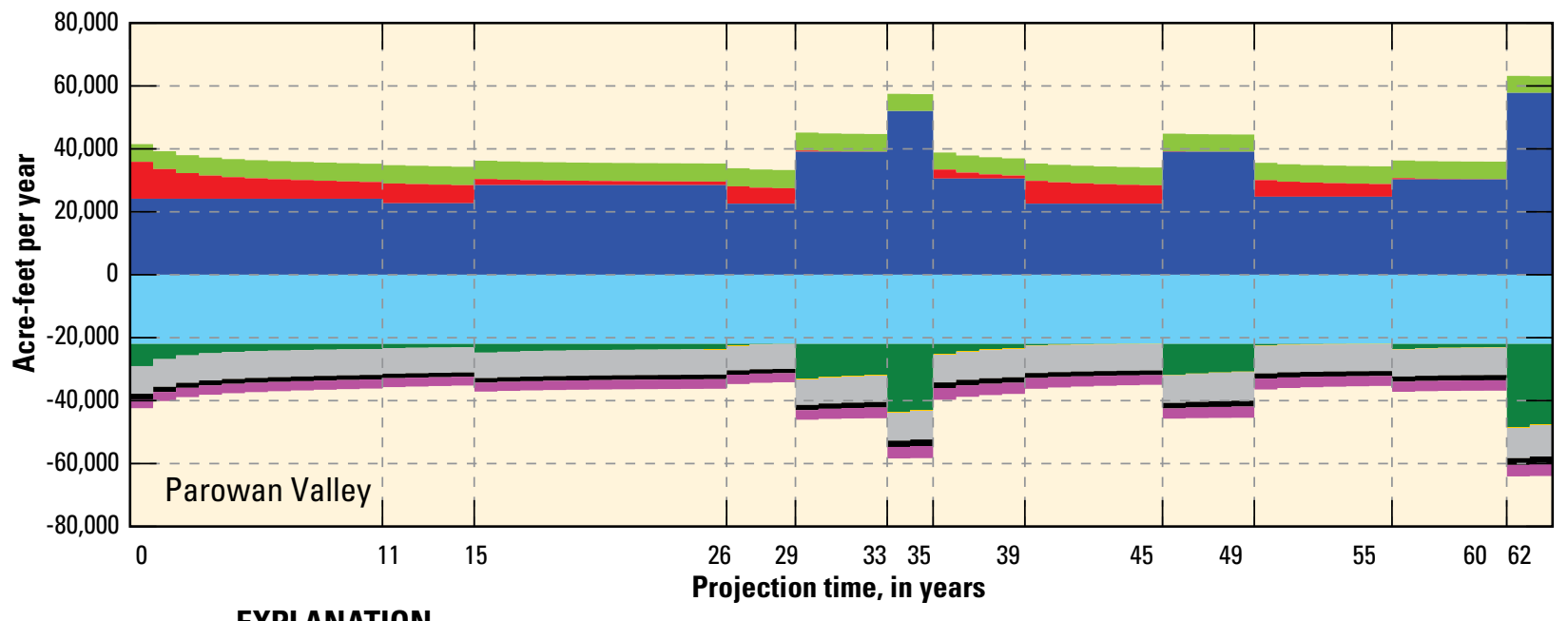

\section{EXPLANATION}

Recharge

Discharge to wells

Storage removed from aquifer

Storage added to aquifer

Discharge to evapotranspiration (ETg)

Discharge to mountain streams

Discharge to mountain and valley springs

Flow to Cedar City Valley (HA 282)

Flow from Beaver Valley (HA 283)

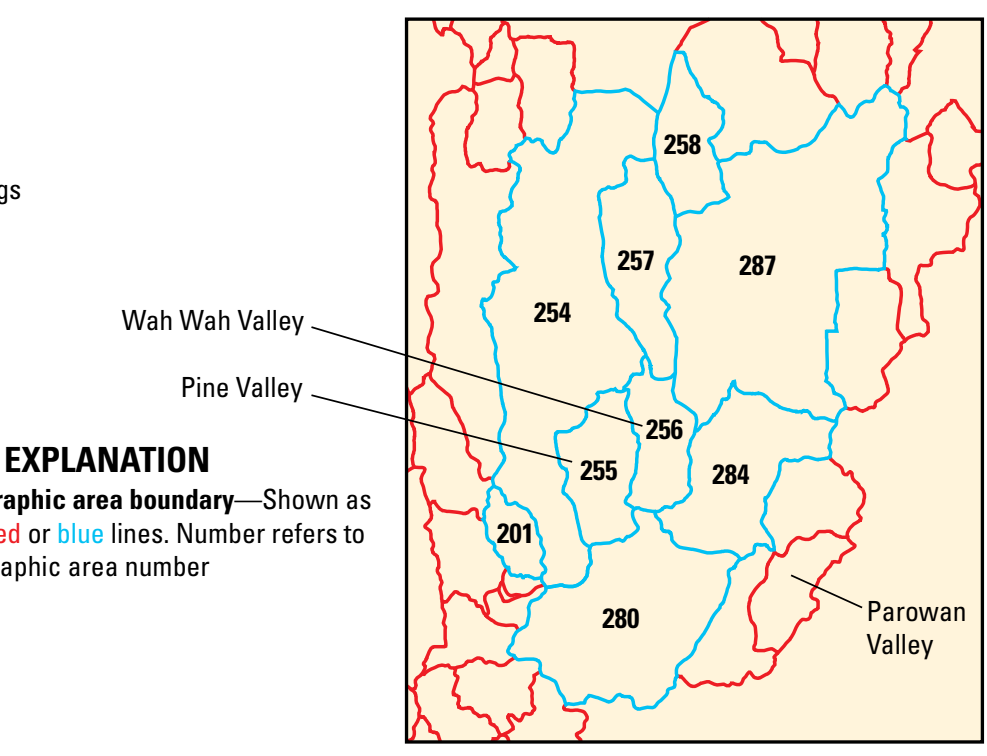

\section{EXPLANATION}

Discharge to wells

Storage removed from aquife

Reduction in discharge to evapotranspiration (ETg)

Reduction in discharge to springs and ETg simulated as drains

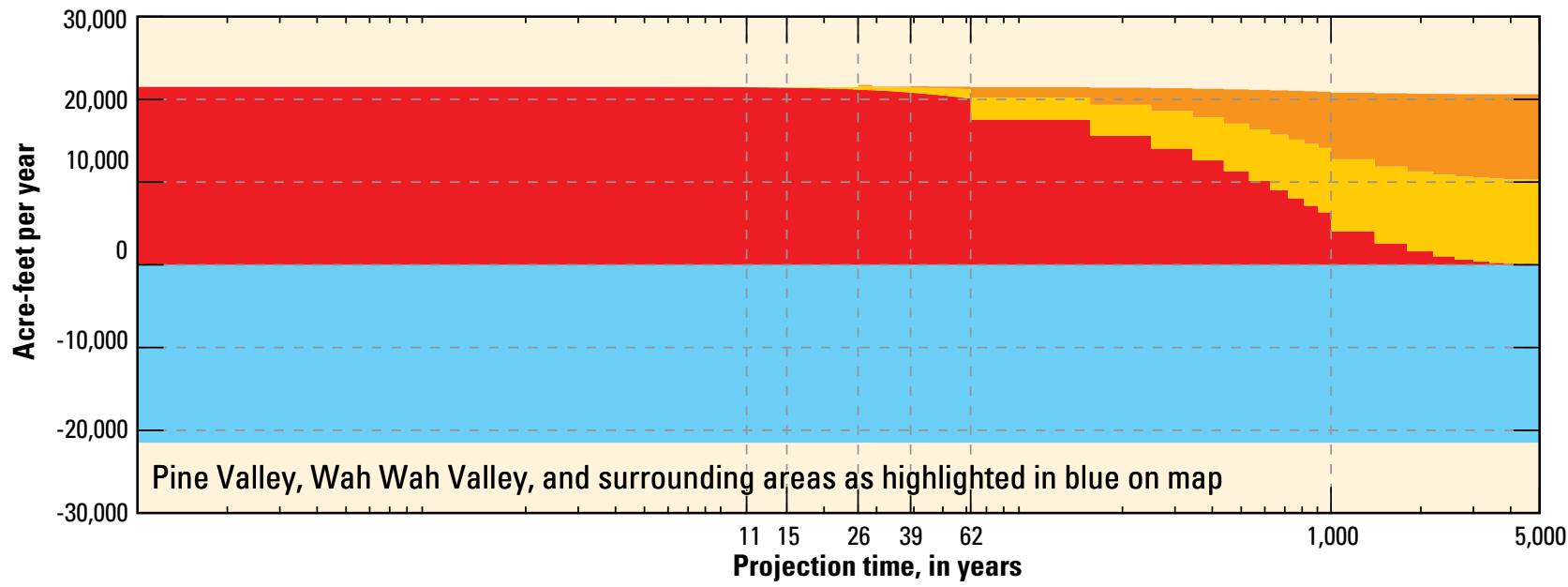

Figure 32. Groundwater-budget components for the projection stress periods of the GBCAAS v. 3.0 groundwater model, model focus area, Utah and Nevada. 

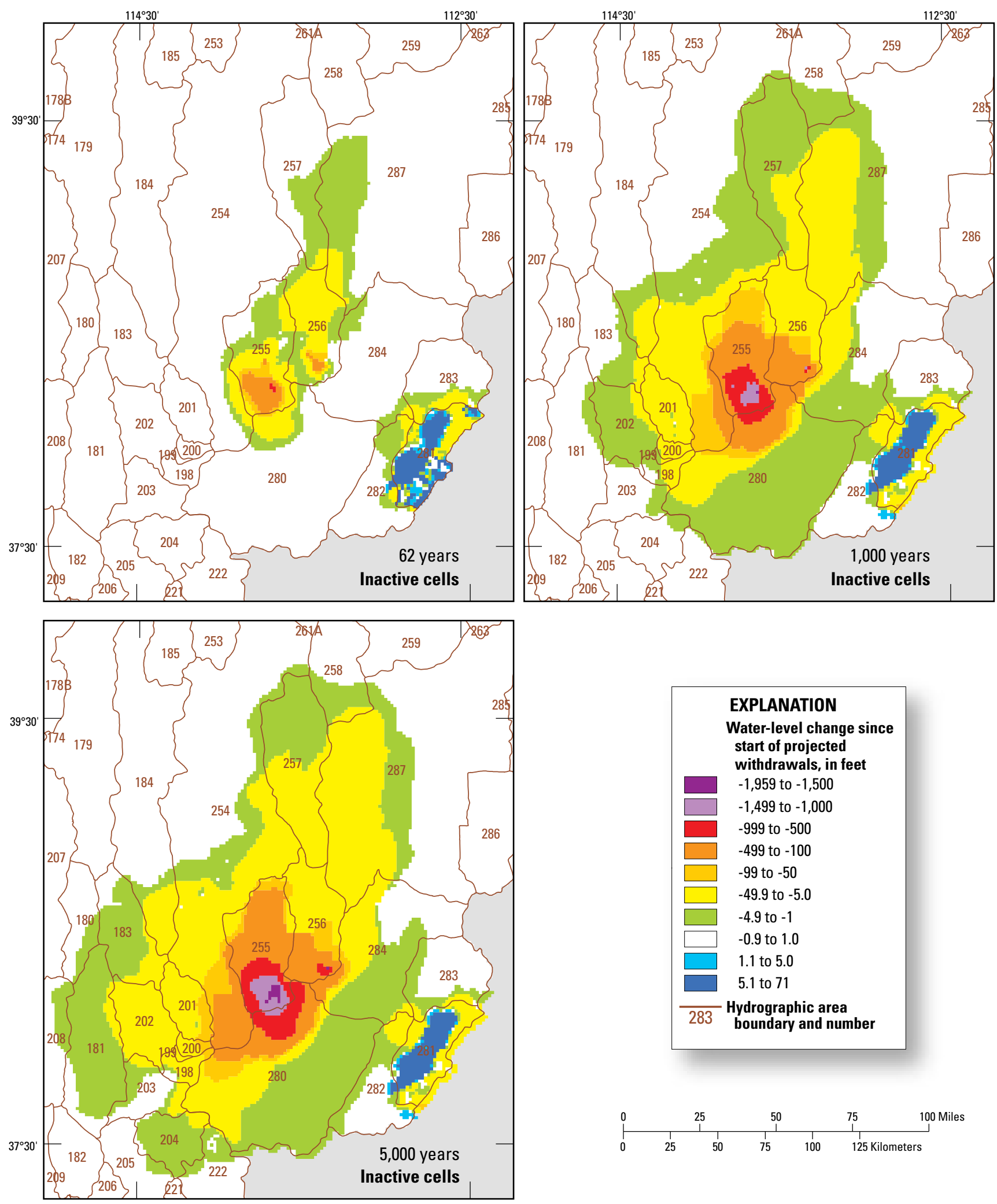

Figure 33. Simulated water-level changes caused by reduced withdrawals in Parowan Valley and increased withdrawals in Pine and Wah Wah Valleys in the GBCAAS v. 3.0 groundwater model, Utah and Nevada. 
Table 12. Reduction in natural discharge of at least 5 percent of initial discharge or rate of withdrawal as a result of withdrawals in Pine and Wah Wah Valleys during the projection simulation of the GBCAAS v. 3.0 groundwater model, model focus area and surrounding areas, Utah and Nevada.

[ETg; Evapotranspiration of groundwater]

\begin{tabular}{|c|c|c|c|c|c|c|c|c|c|c|}
\hline Prediction name & $\begin{array}{c}\text { Stress } \\
\text { period of } \\
\text { projection }\end{array}$ & $\begin{array}{c}\text { Elapsed } \\
\text { projection } \\
\text { time } \\
\text { (years) }\end{array}$ & $\begin{array}{c}\text { Discharge at } \\
\text { end of stress } \\
\text { period } 16 \\
\text { (cubic feet } \\
\text { per day) }\end{array}$ & $\begin{array}{c}\text { Discharge at } \\
\text { end of stress } \\
\text { period } \\
\text { (cubic feet } \\
\text { per day) }\end{array}$ & $\begin{array}{c}\text { Capture of } \\
\text { discharge } \\
\text { (cubic feet } \\
\text { per day) }\end{array}$ & $\begin{array}{c}\text { Capture of } \\
\text { discharge } \\
\text { (acre-feet } \\
\text { per year) }\end{array}$ & $\begin{array}{l}\text { Capture as } \\
\text { percent of } \\
\text { discharge in } \\
\text { stress } \\
\text { period } 16\end{array}$ & $\begin{array}{c}\text { Capture as } \\
\text { percent of } \\
\text { withdrawal of } \\
21,500 \text { acre- } \\
\text { feet per year }\end{array}$ & $\begin{array}{l}\text { Description of } \\
\text { observation }\end{array}$ & $\begin{array}{l}\text { Hydro- } \\
\text { graphic } \\
\text { area } \\
\text { number }\end{array}$ \\
\hline \multicolumn{11}{|c|}{ Discharge locations affected by the end of 26 years } \\
\hline gha256_1_19 & 19 & 26 & $-89,222$ & $-83,502$ & 5,719 & 48 & 6.4 & 0.22 & Wah Wah Springs & 256 \\
\hline gha256_1_20 & 20 & 29 & $-89,222$ & $-82,267$ & 6,955 & 58 & 7.8 & 0.27 & Wah Wah Springs & 256 \\
\hline gha256_1_21 & 21 & 33 & $-89,222$ & $-80,517$ & 8,704 & 73 & 9.8 & 0.34 & Wah Wah Springs & 256 \\
\hline gha256_1_22 & 22 & 35 & $-89,222$ & $-79,604$ & 9,618 & 81 & 11. & 0.38 & Wah Wah Springs & 256 \\
\hline gha256_1_23 & 23 & 39 & $-89,222$ & $-77,711$ & 11,510 & 97 & 13. & 0.45 & Wah Wah Springs & 256 \\
\hline gha256_1_24 & 24 & 45 & $-89,222$ & $-74,735$ & 14,487 & 121 & 16. & 0.56 & Wah Wah Springs & 256 \\
\hline gha256_1_25 & 25 & 49 & $-89,222$ & $-72,674$ & 16,547 & 139 & 19. & 0.65 & Wah Wah Springs & 256 \\
\hline gha256_1_26 & 26 & 55 & $-89,222$ & $-69,495$ & 19,727 & 165 & 22. & 0.77 & Wah Wah Springs & 256 \\
\hline gha256_1_27 & 27 & 60 & $-89,222$ & $-66,783$ & 22,439 & 188 & 25. & 0.88 & Wah Wah Springs & 256 \\
\hline gha256_1_28 & 28 & 62 & $-89,222$ & $-65,684$ & 23,538 & 197 & 26. & 0.92 & Wah Wah Springs & 256 \\
\hline gha256_1_29 & 29 & 1,000 & $-89,222$ & 0 & 89,222 & 748 & 100 & 3.5 & Wah Wah Springs & 256 \\
\hline gha256_1_30 & 30 & 5,000 & $-89,222$ & 0 & 89,222 & 748 & 100 & 3.5 & Wah Wah Springs & 256 \\
\hline \multicolumn{11}{|c|}{ Discharge locations affected by the end of 1,000 years } \\
\hline ET257_29 & 29 & 1,000 & $-4,046,468$ & $-3,320,151$ & 726,317 & 6,090 & 18. & 28. & ETg in Tule Valley & 257 \\
\hline ET257_30 & 30 & 5,000 & $-4,046,468$ & $-3,102,909$ & 943,559 & 7,912 & 23. & 37. & ETg in Tule Valley & 257 \\
\hline ET2872_29 & 29 & 1,000 & $-324,607$ & $-289,549$ & 35,058 & 294 & 11. & 1.4 & ETg north of Sevier Lake & 287 \\
\hline ET2872_30 & 30 & 5,000 & $-324,607$ & $-277,440$ & 47,167 & 395 & 15. & 1.8 & ETg north of Sevier Lake & 287 \\
\hline ET2873_29 & 29 & 1,000 & $-185,832$ & $-99,955$ & 85,877 & 720 & 46. & 3.3 & ETg near Sevier Lake & 287 \\
\hline ET2873_30 & 30 & 5,000 & $-185,832$ & $-75,540$ & 110,292 & 925 & 59. & 4.3 & ETg near Sevier Lake & 287 \\
\hline et34spring29 & 29 & 1,000 & $-130,849$ & $-112,035$ & 18,814 & 158 & 14. & 0.73 & ETg in Spring Valley & 201 \\
\hline et34spring 30 & 30 & 5,000 & $-130,849$ & $-86,324$ & 44,525 & 373 & 34. & 1.7 & ETg in Spring Valley & 201 \\
\hline et39beryl29 & 29 & 1,000 & $-2,841,508$ & $-2,547,619$ & 293,888 & 2,464 & 10. & 11. & $\begin{array}{l}\text { ETg in Beryl-Enterprise } \\
\text { Area }\end{array}$ & 280 \\
\hline et39beryl30 & 30 & 5,000 & $-2,841,508$ & $-2,385,673$ & 455,835 & 3,822 & 16. & 18. & $\begin{array}{l}\text { ETg in Beryl-Enterprise } \\
\text { Area }\end{array}$ & 280 \\
\hline gha254_8_29 & 29 & 1,000 & $-842,280$ & $-711,174$ & 131,106 & 1,099 & 16. & 5.1 & Big Springs & 254 \\
\hline gha254_8_30 & 30 & 5,000 & $-842,280$ & $-616,426$ & 225,853 & 1,894 & 27. & 8.8 & Big Springs & 254 \\
\hline S254_clay_29 & 29 & 1,000 & $-33,506$ & $-29,325$ & 4,181 & 35 & 12. & 0.16 & Clay Spring & 254 \\
\hline S254_clay_30 & 30 & 5,000 & $-33,506$ & $-26,259$ & 7,247 & 61 & 22. & 0.28 & Clay Spring & 254 \\
\hline S254_dear_29 & 29 & 1,000 & $-551,642$ & $-517,491$ & 34,151 & 286 & 6.2 & 1.3 & Dearden Spring Group & 254 \\
\hline S254_dear_30 & 30 & 5,000 & $-551,642$ & $-492,294$ & 59,348 & 498 & 11. & 2.3 & Dearden Spring Group & 254 \\
\hline \multicolumn{11}{|c|}{ Discharge locations affected by the end of 5,000 years } \\
\hline et34lake30 & 30 & 5,000 & $-371,228$ & $-347,677$ & 23,551 & 197 & 6.3 & 0.92 & ETg in Lake Valley & 183 \\
\hline et39Milf30 & 30 & 5,000 & $-3,774,872$ & $-3,591,940$ & 182,932 & 1,534 & 4.8 & 7.10 & ETg in Milford Area & 284 \\
\hline gFishSpr30 & 30 & 5,000 & $-2,747,668$ & $-2,616,911$ & 130,756 & 1,096 & 4.8 & 5.10 & Fish Springs & 254 \\
\hline
\end{tabular}




\section{Model Limitations}

This model was developed to simulate general groundwater flow throughout the model focus area. It was not developed to simulate local effects of withdrawals or water budgets on a cell-by-cell basis. All groundwater flow models are based on a limited amount of data and are simplifications of natural systems. Model limitations are a consequence of simplifications, inadequacies, or inaccuracies in (1) representation of the geologic complexity in the hydrogeologic framework and model, (2) representation of recharge and discharge boundaries, and (3) observations used to calibrate the model. These limitations are described in Brooks and others (2014, p. 84-85) and are summarized here.

Limitations exist in the numerical flow model because of the difficulties inherent in the interpretation and representation of the complex geometry and spatial variability of hydrogeologic materials and structures in the hydrogeologic framework and because of the application of that framework to the model cell size. Detailed stratigraphy not represented in the hydrogeologic framework may cause some of mismatch between simulated and observed hydraulic gradients and heads. It is possible that different parameter zone boundaries could be selected that would provide a similar or better model fit and that additional zones exist that are not simulated because geologic or hydrologic data were not available to delineate them. It is also possible that faults that are not simulated with the HFB Package could act as similar barriers to groundwater flow, but that water-level data were not available to delineate these areas.

Recharge probably varies more across the assigned zones than is simulated. For instance, recharge is dependent on vertical hydraulic conductivity of the material both at the surface and at the groundwater table. Flow can be horizontal at either of these locations until a more permeable material is encountered. Recharge is also dependent on irrigation practices and can vary on a field-by-field basis.

Observations of water levels and groundwater discharge constrain model calibration. Uncertainty in these observations introduces uncertainty in the results of the numerical model. Although the water-level and discharge observations used in this model were analyzed prior to and throughout calibration, there is uncertainty regarding the accuracy of the observation data. Discharge observations were based on limited data and might not represent the system correctly.

\section{Appropriate Uses of the Model}

This model was developed to test the conceptual groundwater budget in the model focus area and to develop a tool to estimate the changes in storage in Parowan Valley (HA 281). The model can also be used to investigate other effects on the natural system, including (1) the effects of different amounts of recharge, (2) different interpretations of the extent or offset of faults or fault zones, or (3) different conceptual models of depositional environments or tectonic/structural events that would affect the spatial variation of hydraulic properties.

Although this is a transient model, storage properties were not calibrated outside of Parowan Valley (HA 281). The model can be used for simulation of changes outside of Parowan Valley, but those changes would be based on the storage properties determined for Parowan Valley, which might not accurately represent storage properties in other areas of the model.

The model and statistics from programs such as UCODE_2014 (Poeter and others, 2008 and 2014) and OPR-PPR (Tonkin and others, 2007) can be used to guide data collection of greatest use in reducing prediction uncertainty. The model can be used less formally to guide data collection by consideration of zonation and parameter values that were needed to achieve calibration in select areas and what data could be collected to verify or dispute the model parameters.

\section{Summary}

The groundwater model described in this report is a new version of previously published steady-state numerical groundwater flow models of the Great Basin carbonate and alluvial aquifer system, and was developed in conjunction with U.S. Geological Survey (USGS) studies in Parowan, Pine, and Wah Wah Valleys, Utah. This version of the model is GBCAAS v. 3.0 and supersedes previous versions. The objectives of the model for Parowan Valley were to simulate revised conceptual estimates of recharge and discharge, to estimate aquifer storage properties and the amount of reduction in storage as a result of historical groundwater withdrawals, and to assess reduction in groundwater withdrawals necessary to mitigate groundwater-level declines in the basin. The objectives of the model for the area near Pine and Wah Wah Valleys were to recalibrate the model using recent observations of groundwater levels and evapotranspiration of groundwater; to provide revised estimates of simulated recharge, hydraulic conductivity, and interbasin flow; and to simulate the effects of proposed groundwater withdrawals on the regional flow system. Meeting these objectives required the addition of 15 transient calibration stress periods and 14 projection stress periods, aquifer storage properties, historical withdrawals in Parowan Valley, and observations of water-level changes in Parowan Valley.

Fifteen transient stress periods were added to the previous steady-state model to allow calibration to transient conditions 
of recharge and groundwater withdrawals in Parowan Valley from March 1940 to November 2013. Fourteen stress periods were used for a projection simulation of 5,000 years. Recharge in Parowan Valley and withdrawals from wells in Parowan Valley and two nearby wells in Cedar City Valley vary for each stress period. Stresses, including recharge, are the same in each stress period as in the steady-state stress period for all areas outside of Parowan Valley, and simulated water-levels do not change during the transient calibration period outside of areas near Parowan Valley. Simulated storage properties outside of Parowan Valley were set the same as the Parowan Valley properties and are not considered calibrated.

Model observations in GBCAAS v. 3.0 are groundwater levels at wells and discharge locations; water-level changes; and discharge to springs, ETg, rivers, and lakes. All observations used in the model outside of Parowan Valley are considered representative of steady-state conditions. Composite scaled sensitivities indicate the observations of discharge to rivers and springs provide more information about model parameters in the model focus area than do water-level observations. Water levels and water-level changes, however, provide the only information about specific yield and specific storage parameters and provide more information about recharge and withdrawals in Parowan Valley than any other observation group. Model evaluation indicated this model provides a reasonable representation of the groundwater system.

Comparisons of simulated water levels and measured water levels in Parowan Valley indicated that the model fits the overall trend of declining water levels and provides reasonable estimates of long-term reduction in storage and of storage changes from 2012 to 2013. The conceptual and simulated groundwater budgets for Parowan Valley from November 2012 to November 2013 are similar, with recharge of about 20,000 acre-feet and discharge of about 45,000 acre-feet. In the transient simulation, historical withdrawals (averaging 28,000 acre-feet per year) cause major changes in the groundwater system in Parowan Valley, including the cessation of almost all natural discharge in the valley to ETg and springs and the long-term removal of water from storage.

Simulated recharge in Pine Valley of 11,000 acre-feet per year (acre- $\mathrm{ft} / \mathrm{yr}$ ) and in Wah Wah Valley of 3,200 acre-ft/yr is substantially less in GBCAAS v. 3.0 than in previous model versions. In addition, the valleys have less simulated inflow from and outflow to other hydrographic areas than in previous model versions. The effects of groundwater development in these valleys, however, are independent of the amount of water recharging in and flowing through the valleys. Groundwater withdrawals in Pine and Wah Wah Valleys will decrease groundwater storage (causing drawdown) until discharge in surrounding areas and mountain springs around the two valleys is reduced by the rate of withdrawal.

The model was used to estimate that reducing withdrawals in Parowan Valley from 35,000 to about 22,000 acre-ft/yr would likely stabilize groundwater levels in the valley if recharge varies as it did from about 1950 to 2012. The model simulations also demonstrate that withdrawals of
15,000 acre-ft/yr from Pine Valley and 6,500 acre-ft/yr from Wah Wah Valley could ultimately (long-term steady-state) cause water-level declines of more than 1,900 feet near the withdrawal wells and of more than 5 feet in an area of about 10,500 square miles. The timing of drawdown and capture and the ultimate amount of drawdown are dependent on the proximity of the withdrawals to areas of simulated natural groundwater discharge, simulated transmissivity, and simulated storage properties. The model projections are considered a representation of possible effects.

\section{References}

Alley, W.M., Reilly, T.E., and Franke, O.L, 1999, Sustainability of ground-water resources: U.S. Geological Survey Circular 1186, 79 p.

Anderman, E.R., and Hill, M.C., 2000, MODFLOW-2000, the U.S. Geological Survey modular ground-water model-Documentation of the Hydrogeologic-Unit Flow (HUF) Package: U.S. Geological Survey Open-File Report 2000-342, 89 p.

Anderman, E.R., and Hill, M.C., 2003, MODFLOW-2000, the U.S. Geological Survey modular ground-water modelThree additions to the Hydrogeologic-Unit Flow (HUF) Package: Alternative storage for the uppermost active cells, flows in hydrogeologic units, and the hydraulic-conductivity depth-dependence (KDEP) capability: U.S. Geological Survey Open-File Report 2003-347, 36 p.

Banta, E.R., and Provost, A.M., 2008, User guide for HUFPrint, a tabulation and visualization utility for the Hydrogeologic-Unit Flow (HUF) Package of MODFLOW: U.S. Geological Survey Techniques and Methods 6-A27, 13 p.

Barlow, P.M., and Leake, S.A., 2012, Streamflow depletion by wells-Understanding and managing the effects of groundwater pumping on streamflow: U.S. Geological Survey Circular 1376, 84 p.

Bjorklund, L.J., Sumsion, C.T., and Sandberg, G.W., 1978, Ground-water resources of the Parowan-Cedar City drainage basin, Iron County, Utah: Utah Department of Natural Resources Technical Publication No. 60, 93 p., 8 plates.

Bredehoeft, J.D., Papadopulos, S.S., and Cooper, H.H., 1982, Groundwater: the water-budget myth in Scientific Basis of Water-Resource Management, Studies in Geophysics: Washington, D.C., National Academy Press p. 51-57.

Brooks, L.E., 2017, MODFLOW-LGR datasets for the Great Basin carbonate and alluvial aquifer system model version 3.0: Revisions in southwestern Utah and east central Nevada: U.S. Geological Survey data release, http://doi.org/10.5066/F76T0JW1. 
Brooks, L.E., Masbruch, M.D., Sweetkind, D.S., and Buto, S.G., 2014, Steady-state numerical flow model of the Great Basin carbonate and alluvial aquifer system study area: U.S. Geological Survey Scientific Investigations Report 20145213, 124 p., 2 plates.

Brooks, L.E., and Mason, J.L., 2005, Hydrology and simulation of ground-water flow in Cedar Valley, Iron County, Utah: U.S. Geological Survey Scientific Investigations Report 2005-5170, 114 p.

Burden, C.B., and others, 2016, Groundwater conditions in Utah, Spring of 2016: Utah Department of Natural Resources Cooperative Investigations Report No. 57, 118 p.

Caine, J.S., Evans, J.P., and Forster, C.B., 1996, Fault zone architecture and permeability structure: Geology, v. 24, p. 1025-1028, doi: 10.1130/0091-7613.

Cederberg, J.R., Sweetkind, D.S., Buto, S.G., and Masbruch, M.D., 2011, Three-dimensional hydrogeologic framework, appendix 1 of Heilweil, V.M., and Brooks, L.E., eds., Conceptual model of the Great Basin carbonate and alluvial aquifer system: U.S. Geological Survey Scientific Investigations Report 2010-5193, p. 127-142.

Christensen, Steen, and Cooley, R.L., 1999, Evaluation of confidence intervals for a steady-state leaky aquifer model: Advances in Water Resources, v. 22, no. 8, p. 807-817.

Faunt, C.C., Blainey, J.B., Hill, M.C., D’Agnese, F.A., and O'Brien, G.M., 2010, Transient numerical model, chapter F of Belcher, W.R., and Sweetkind, D.S., eds., 2010, Death Valley regional groundwater flow system, Nevada and California-Hydrogeologic framework and transient groundwater flow model: U.S. Geological Survey Professional Paper 1711, p. 251-344.

Flint, A.L., Flint, L.E., and Masbruch, M.D., 2011, Input, calibration, uncertainty, and limitations of the Basin Characterization Model, appendix 3 of Heilweil, V.M., and Brooks, L.E., eds., Conceptual model of the Great Basin carbonate and alluvial aquifer system: U.S. Geological Survey Scientific Investigations Report 2010-5193, p. 149-164.

Gardner, P.M., Masbruch, M.D., Plume, R.W., and Buto, S.G., 2011, Regional potentiometric-surface map of the Great Basin carbonate and alluvial aquifer system in Snake Valley and surrounding areas, Juab, Millard, and Beaver Counties, Utah, and White Pine and Lincoln Counties, Nevada: U.S. Geological Survey Scientific Investigations Map 3193, 2 sheets.

Haitjema, Henk, 2003, The role of hand-calculations in groundwater flow modeling in Poeter, E.P., Zheng, Chunmiao, Hill, M.C., and Doherty, John, organizing committee, MODFLOW and More 2003: Understanding through modeling, Golden, Colorado, [Proceedings], p. 441-445.
Harbaugh, A.W., 1990, A computer program for calculating subregional water budgets using results from the U.S. Geological Survey modular three-dimensional finite-difference ground-water flow model: U.S. Geological Survey OpenFile Report 90-392, 24 p.

Harbaugh, A.W., 2005, MODFLOW-2005, the U.S. Geological Survey modular ground-water model-The groundwater flow process: U.S. Geological Survey Techniques and Methods 6-A16, variously $\mathrm{p}$.

Harbaugh, A.W., and Hill, M.C., 2009, Obs.pdf provided with MODFLOW-2005 model, http://water.usgs.gov/nrp/ gwsoftware/modflow2005/modflow2005.html, accessed on February 14, 2013.

Harrill, J.R., Gates, J.S., and Thomas, J.M., 1988, Major ground-water flow systems in the Great Basin region of Nevada, Utah, and adjacent states: U.S. Geological Survey Hydrologic Investigations Atlas HA-694-C, 2 sheets, scale 1:1,000,000.

Harrill, J.R., and Prudic, D.E., 1998, Aquifer systems in the Great Basin region of Nevada, Utah, and adjacent states - Summary Report: U.S. Geological Survey Professional Paper 1409-A, 66 p.

Heilweil, V.M., and Brooks, L.E., eds., 2011, Conceptual model of the Great Basin carbonate and alluvial aquifer system: U.S. Geological Survey Scientific Investigations Report 2010-5193, 191 p.

Hill, M.C., and Tiedeman, C.R., 2007, Effective groundwater model calibration: with analysis of data, sensitivities, predictions, and uncertainty: Hoboken, N.J., John Wiley and Sons, Inc., 455 p.

Holmes, W.F., 1984, Ground-water hydrology and projected effects of groundwater withdrawals in the Sevier Desert, Utah: Utah Department of Natural Resources Technical Publication No. 79, 54 p., 1 pl.

Marston, T.M., 2017, Water resources of Parowan Valley, Iron County, Utah: U.S. Geological Survey Scientific Investigations Report 2017-5033, 45 p.

Masbruch, M.D., 2011a, Current study groundwater recharge estimates for predevelopment conditions and ranges of previously reported estimates of groundwater recharge for each hydrographic area within the Great Basin carbonate and alluvial aquifer system study area, appendix 4 of Heilweil, V.M., and Brooks, L.E., eds., Conceptual model of the Great Basin carbonate and alluvial aquifer system: U.S. Geological Survey Scientific Investigations Report 2010-5193, p. $165-170$. 
Masbruch, M.D., 2011b, Current study groundwater discharge estimates for predevelopment conditions and ranges of previously reported estimates of groundwater discharge for each hydrographic area within the Great Basin carbonate and alluvial aquifer system study area, appendix 5 of Heilweil, V.M., and Brooks, L.E., eds., Conceptual model of the Great Basin carbonate and alluvial aquifer system: U.S. Geological Survey Scientific Investigations Report 2010-5193, p. 171-176.

Masbruch, M.D., Gardner, P.M., and Brooks, L.E., 2014, Hydrology and numerical simulation of groundwater movement and heat transport in Snake Valley and surrounding areas, Juab, Millard, and Beaver Counties, Utah, and White Pine and Lincoln Counties, Nevada: U.S. Geological Survey Scientific Investigations Report 2014-5103, 108 p. http://dx.doi.org/10.3133/sir20145103.

Masbruch, M.D., Heilweil, V.M., Buto, S.G., Brooks, L.E., Susong, D.D., Flint, A.L., Flint, L.E., and Gardner, P.M., 2011, Estimated groundwater budgets, chapter D of Heilweil, V.M., and Brooks, L.E., eds., Conceptual model of the Great Basin carbonate and alluvial aquifer system: U.S. Geological Survey Scientific Investigations Report 2010 5193, p. 171-176.

Mathey, S.B., ed., 1998, National Water Information System (NWIS): U.S. Geological Survey Fact Sheet 029-98, 2 p.

Mehl, S.W., and Hill, M.C., 2013, MODFLOW-LGR-Documentation of ghost node local grid refinement (LGR2) for multiple areas and the boundary flow and head (BFH2) Package: U.S. Geological Survey Techniques and Methods 6-A44, 43 p.

Poeter, E.P., Hill, M.C., Banta, E.R., Mehl, Steffen, and Christensen, Steen, 2008, UCODE_2005 and six other computer codes for universal sensitivity analysis, calibration, and uncertainty evaluation: U.S. Geological Survey Techniques and Methods 6-A11, $283 \mathrm{p}$.

Poeter, E.P., Hill, M.C., Lu, Dan, Tiedeman, C.R., and Mehl, Steffen, 2014, UCODE_2014, with new capabilities to define parameters unique to predictions, calculate weights using simulated values, estimate parameters with SVD, evaluate uncertainty with MCMC, and more: Integrated Groundwater Modeling Center Report Number GWMI 2014-02, 172 p.

Reilly, T.E., and Harbaugh, A.W., 2004, Guidelines for evaluating ground-water flow models: U.S. Geological Survey Scientific Investigations Report 2004-5038, 30 p.

Robinson, T.W., 1958, Phreatophytes: U.S. Geological Survey Water-Supply Paper 1423, 84 p.
San Juan, C.A., Belcher, W.R., Laczniak, R.J., and Putnam, H.M., 2010, Hydrologic components for model development, chap. C of Belcher, W.R., and Sweetkind, D.S., eds., Death Valley regional ground-water flow system, Nevada and California-Hydrologic framework and transient ground-water flow model: U.S. Geological Survey Professional Paper 1711, p. 95-132.

Stephens, J.C., 1974, Hydrologic reconnaissance of the Wah Wah Valley drainage basin, Millard and Beaver Counties, Utah: Utah Department of Natural Resources Technical Publication No. 47, 53 p.

Stephens, J.C., 1976, Hydrologic reconnaissance of the Pine Valley drainage basin, Millard, Beaver, and Iron Counties, Utah: Utah Department of Natural Resources Technical Publication No. 51, 38 p.

Stolp, B.J., Brooks, L.E., Solder, J.E, 2017, Hydrology and numerical simulation of groundwater flow and streamflow depletion by well withdrawals in the Malad-Lower Bear River Area, Box Elder County, Utah: U.S. Geological Survey Scientific Investigation Report 2017-5011, 113 p., 6 appendixes, https://doi.org/10.3133/sir20175011.

Sweetkind, D.S., Cederberg, J.R., Masbruch, M.D., and Buto, S.G., 2011a, Hydrogeologic framework, chapter B of Heilweil, V.M., and Brooks, L.E., eds., Conceptual model of the Great Basin carbonate and alluvial aquifer system: U.S. Geological Survey Scientific Investigations Report 2010-5193, p. 15-50.

Sweetkind, D.S., Masbruch, M.D., Heilweil, V.M., and Buto, S.G., 2011b, Groundwater flow, chapter C of Heilweil, V.M., and Brooks, L.E., eds., Conceptual model of the Great Basin carbonate and alluvial aquifer system: U.S. Geological Survey Scientific Investigations Report 2010-5193, p. $15-50$.

Thomas, H.E., and Taylor, G.H., 1946, Geology and groundwater resources of Cedar City and Parowan Valleys, Iron County, Utah: U.S. Geological Survey Water-Supply Paper 993, 210 p., 27 plates.

Tonkin, M.J., Tiedeman, C.R., Ely, D.M., and Hill, M.C., 2007, OPR-PPR, a computer program for assessing data importance to model predictions using linear statistics: U.S. Geological Survey Techniques and Methods Report TM-6E2, $115 \mathrm{p}$.

U.S. Geological Survey EROS Data Center, 1999, 1 arc-second (30 meter) National Elevation Dataset: U.S. Geological Survey dataset, accessed September 15, 2008, at http://ned.usgs.gov/. 
Welch, A.H., Bright, D.J., and Knochenmus, L.A., eds., 2007, Water resources of the Basin and Range carbonate-rock aquifer system, White Pine County, Nevada, and adjacent areas in Nevada and Utah: U.S. Geological Survey Scientific Investigations Report 2007-5261, 96 p., 4 pls., with downloadable appendix, at http://pubs.usgs.gov/sir/2007/5261/. 


\section{Appendix 1. Observations and Error Analysis Used in the Groundwater Model}

Table 1-1. Selected springs not simulated explicitly in the GBCAAS v. 3.0 groundwater model, model focus area, Utah and Nevada. [Site identification number: unique identifier in U.S. Geological Survey National Water Information System. Spring name: spring name in the U.S. Geological Survey National Water Information System; - , no data for this item in the U.S. Geological Survey National Water Information System. Abbreviations: HA, hydrographic area; \#, number; GWSI, U.S Geological Survey Groundwater Site Inventory System; ETg, simulated evapotranspiration from groundwater]

\begin{tabular}{|c|c|c|c|c|c|c|c|}
\hline HA \# & HA name & Site identification number & Spring name & $\begin{array}{c}\text { Spring altitude } \\
\text { (feet) }\end{array}$ & $\begin{array}{l}\text { Average dis- } \\
\text { charge (cubic } \\
\text { feet per day) }\end{array}$ & Source of data & Reason for removal from simulation \\
\hline 254 & Snake Valley & 395934113415401 & REDDEN & 4,289 & 61,603 & GWSI & Combined with ETg \\
\hline 257 & Tule Valley & 392527113290901 & COYOTE & 4,420 & 70,587 & GWSI & Combined with ETg \\
\hline 257 & Tule Valley & 392128113305401 & - & 4,420 & 4,812 & GWSI & Combined with ETg \\
\hline 257 & Tule Valley & 392146113310401 & - & 4,418 & 433 & GWSI & Combined with ETg \\
\hline 257 & Tule Valley & 392156113305501 & WILLOW & 4,415 & 3,080 & GWSI & Combined with ETg \\
\hline 283 & Beaver Valley & 381639112394001 & - & 5,840 & 77,004 & GWSI & Combined with area springs \\
\hline
\end{tabular}

Table 1-2. Springs added to the GBCAAS v. 3.0 groundwater model, model focus area, Utah and Nevada.

[HA, hydrographic area; \#, number]

\begin{tabular}{|c|c|c|c|c|c|c|c|c|}
\hline $\begin{array}{l}\text { Observation } \\
\text { name }\end{array}$ & HA\# & $\begin{array}{l}\text { Hydrographic } \\
\text { area name }\end{array}$ & $\begin{array}{l}\text { Model } \\
\text { row }\end{array}$ & $\begin{array}{l}\text { Model } \\
\text { column }\end{array}$ & $\begin{array}{l}\text { Simulated } \\
\text { altitude } \\
\text { (feet) }\end{array}$ & $\begin{array}{c}\text { Model } \\
\text { observation } 1 \\
\text { (cubic feet } \\
\text { per day) }\end{array}$ & $\begin{array}{l}\text { Model variance } \\
\text { (cubic feet } \\
\text { per day, squared) }\end{array}$ & Source of observation and variance data \\
\hline S254_clay & 254 & Snake Valley & 258 & 237 & 5,381 & $-30,653$ & 497,056 & Masbruch and others (2014, model archive) \\
\hline S254_dearden & 254 & Snake Valley & 264 & 234 & 5,423 & $-576,335$ & $4,019,166,390$ & Masbruch and others (2014, model archive) \\
\hline S254_miller & 254 & Snake Valley & 208 & 243 & 4,744 & $-32,878$ & $2,188,944$ & Masbruch and others (2014, model archive) \\
\hline S281area & 281 & Parowan Valley & $\begin{array}{l}321 \text { to } \\
323\end{array}$ & $\begin{array}{l}301 \text { to } \\
303\end{array}$ & $\begin{array}{l}5,702 \\
\text { to } \\
5,738\end{array}$ & $-238,500$ & $14,223,000,000$ & $\begin{array}{l}\text { Observation from Thomas and Taylor ( } 1946 \text {, } \\
\text { p. } 170-172 \text {, Paragonah district). Variance cal- } \\
\text { culated from estimated coefficient of variation } \\
\text { of } 0.5 \text {. }\end{array}$ \\
\hline${ }^{2}$ S281area2 & 281 & Parowan Valley & & & & 0 & $12,713,013,500$ & $\begin{array}{l}\text { Marston, 2017, p. } 28 \text {. Model variance set high } \\
\text { to minimize effect of } 0 \text { discharge on regression. }\end{array}$ \\
\hline S281_1 & 281 & Parowan Valley & 325 & 306 & 6,880 & $-436,153$ & $9,386,909,680$ & $\begin{array}{l}\text { Red Creek above power plant diversion near } \\
\text { Paragonah, UT (Marston, 2017, table } 2,2013 \\
\text { measurements) }+400 \text { gallons per minute } \\
\text { diverted above measurement location (Marston, } \\
2017, \text { p. 10). Measurements have a coefficient } \\
\text { of variation of } 0.22 \text {. Assume } 0.22 \text { applies to } \\
\text { total measurement to get model variance }\end{array}$ \\
\hline $\mathrm{S} 281 \_2$ & 281 & Parowan Valley & 326 & 305 & 6,760 & $-69,195$ & $1,181,107,890$ & $\begin{array}{l}\text { South Fork Red Creek near Paragonah, UT } \\
\text { (Marston, 2017, table 2, } 2013 \text { measurements). }\end{array}$ \\
\hline
\end{tabular}

\footnotetext{
${ }^{1}$ Discharge is considered negative in MODFLOW. A larger discharge, therefore, is a more negative number.
}

${ }^{2}$ Discharge in model stress period 16, which simulates conditions in 2013. 
Table 1-3. Changes to springs simulated using the Drain Package in the GBCAAS v. 3.0 groundwater model, model focus area, Utah and Nevada.

[Empty rows indicate the spring is not simulated in that model layer]

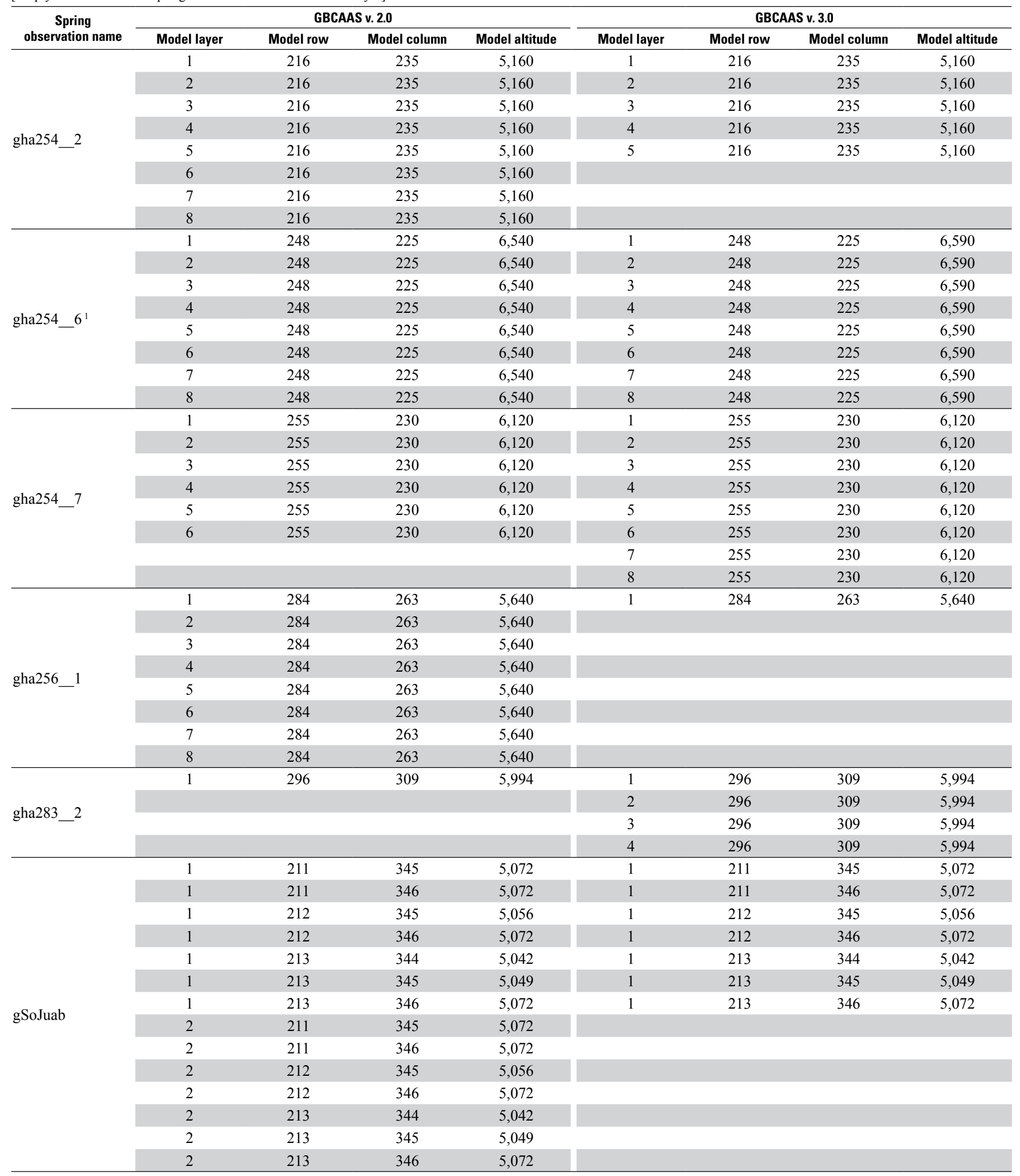

\footnotetext{
${ }^{1}$ Simulated altitude of spring was lowered in GBCAAS v. 1.0 and GBCAAS v. 2.0 to allow simulated discharge to more closely match observed discharge.
} Changes in the GBCAAS v. 3.0 model allow sufficient simulated discharge with the spring at the correct altitude. 
Table 1-4. Changes to the riverbed hydraulic conductivity parameter and river observations in the GBCAAS v. 3.0 groundwater model, model focus area, Utah and Nevada.

\begin{tabular}{|c|c|c|c|c|c|c|c|c|c|c|}
\hline \multirow[b]{2}{*}{$\begin{array}{l}\text { Model } \\
\text { layer }\end{array}$} & \multirow[b]{2}{*}{$\begin{array}{l}\text { Model } \\
\text { row }\end{array}$} & \multirow[b]{2}{*}{$\begin{array}{l}\text { Model } \\
\text { column }\end{array}$} & \multicolumn{4}{|c|}{ GBCAAS v. 2.0} & \multicolumn{4}{|c|}{ GBCAAS v. 3.0} \\
\hline & & & $\begin{array}{c}\text { River } \\
\text { observation } \\
\text { name }\end{array}$ & $\begin{array}{c}\text { River observation } \\
\text { value (cubic feet } \\
\text { per day) }\end{array}$ & $\begin{array}{l}\text { Parameter } \\
\text { name }\end{array}$ & $\begin{array}{c}\text { Parameter } \\
\text { value }\end{array}$ & $\begin{array}{c}\text { River } \\
\text { observation } \\
\text { name }\end{array}$ & $\begin{array}{c}\text { River observation } \\
\text { value (cubic feet } \\
\text { per day) }\end{array}$ & $\begin{array}{l}\text { Parameter } \\
\text { name }\end{array}$ & $\begin{array}{c}\text { Parameter } \\
\text { value }\end{array}$ \\
\hline 1 & $221-223$ & $341-346$ & r10219000 & $-1,813,104$ & virgin & 0.5 & r10219000 & $-1,813,104$ & val_wide & 50. \\
\hline 1 & $207-221$ & $321-340$ & r10224000 & $-3,880,026$ & virgin & 0.5 & r10224000 & $-3,880,026$ & val_wide & 50. \\
\hline 1 & $324-327$ & $306-310$ & & & mountain & 50. & r10241400 & $-52,498$ & mountain & 50. \\
\hline 1 & $327-329$ & $307-308$ & & & mountain & 50. & r10241430 & $-84,586$ & mountain & 50. \\
\hline 1 & $332-337$ & $295-297$ & rcedarcity & $-1,846,166$ & mountain & 50. & r10241600 & $-128,097$ & mountain & 50. \\
\hline 1 & $329-336$ & $298-304$ & & & mountain & 50. & r10241500 & $-779,760$ & mountain & 50. \\
\hline 1 & $339-345$ & 289-299 & & & mountain & 50. & r10242000 & $-801,225$ & mountain & 50. \\
\hline
\end{tabular}

The following tables are distributed as part of this report in Microsoft ${ }^{\circledR}$ Excel 2010 format and are available for download at https://doi.org/10.3133/sir20175072.

Table 1-5. Well data, water-level observation, uncertainty, simulated values, and simulated residuals for observations of water levels in wells in the GBCAAS v. 3.0 groundwater model, Great Basin carbonate and alluvial aquifer system study area.

Table 1-6. Comparison of observed and simulated discharge for each discharge observation in the GBCAAS v. 3.0 groundwater model, Great Basin carbonate and alluvial aquifer system study area. 


\section{Appendix 2. Model Parameter Statistics}

This appendix presents statistics for model parameters in the GBCAAS v. 3.0 groundwater model in the model focus area described in this report. The statistics for all parameters are available in the model archive. Distributions of parameters are also available from data provided in the model archive.

Table 2-1. Comparison of parameter values in different versions of the Great Basin carbonate and alluvial aquifer system groundwater model.

[Values rounded to three significant figures. Changes in parameter values are highlighted in red. -, parameter not in model version]

\begin{tabular}{|c|c|c|c|c|c|}
\hline \multicolumn{2}{|c|}{$\begin{array}{l}\text { GBCAAS v. } 1.0 \text { (Brooks and } \\
\text { others, 2014) }\end{array}$} & \multicolumn{2}{|c|}{$\begin{array}{l}\text { GBCAAS v. } 2.0 \text { (Stolp and } \\
\text { others, 2017) }\end{array}$} & \multicolumn{2}{|c|}{ GBCAAS v. 3.0} \\
\hline $\begin{array}{l}\text { Parameter } \\
\text { name }\end{array}$ & $\begin{array}{l}\text { Parameter } \\
\text { value }\end{array}$ & $\begin{array}{l}\text { Parameter } \\
\text { name }\end{array}$ & $\begin{array}{l}\text { Parameter } \\
\text { value }\end{array}$ & $\begin{array}{l}\text { Parameter } \\
\text { name }\end{array}$ & $\begin{array}{l}\text { Parameter } \\
\text { value }\end{array}$ \\
\hline $\operatorname{rch} 42$ & 0.749 & $\operatorname{rch} 42$ & 0.749 & $\operatorname{rch} 42$ & 0.749 \\
\hline $\operatorname{rch} 48$ & 0.4 & $\operatorname{rch} 48$ & 0.4 & $\operatorname{rch} 48$ & 0.4 \\
\hline $\operatorname{rch} 54$ & 1.38 & $\operatorname{rch} 54$ & 1.38 & $\operatorname{rch} 54$ & 1.38 \\
\hline rch62 & 1. & $\operatorname{rch} 62$ & 1. & rch62 & 1. \\
\hline rch117 & 1.1 & $\operatorname{rch} 117$ & 1.1 & rch117 & 1.1 \\
\hline rch140 & 0.701 & $\operatorname{rch} 140$ & 0.701 & $\operatorname{rch} 140$ & 0.701 \\
\hline rch141 & 1.12 & $\operatorname{rch} 141$ & 1.12 & rch141 & 1.12 \\
\hline rch144 & 0.6 & $\operatorname{rch} 144$ & 0.6 & rch144 & 0.6 \\
\hline rch147 & 0.133 & $\operatorname{rch} 147$ & 0.133 & $\operatorname{rch} 147$ & 0.133 \\
\hline $\operatorname{rch} 150$ & 1.3 & $\operatorname{rch} 150$ & 1.3 & $\operatorname{rch} 150$ & 1.3 \\
\hline rch154 & 0.846 & $\operatorname{rch} 154$ & 0.846 & $\operatorname{rch} 154$ & 0.846 \\
\hline rch157 & 0.374 & $\operatorname{rch} 157$ & 0.374 & rch157 & 0.374 \\
\hline rch161 & 0.963 & $\operatorname{rch} 161$ & 0.963 & $\operatorname{rch} 161$ & 0.963 \\
\hline rch172 & 0.436 & $\operatorname{rch} 172$ & 0.436 & $\operatorname{rch} 172$ & 0.436 \\
\hline rch175 & 0.579 & $\operatorname{rch} 175$ & 0.579 & $\operatorname{rch} 175$ & 0.579 \\
\hline rch179 & 1.08 & $\operatorname{rch} 179$ & 1.08 & $\operatorname{rch} 179$ & 1.08 \\
\hline rch180 & 1.62 & $\operatorname{rch} 180$ & 1.62 & $\operatorname{rch} 180$ & 1.62 \\
\hline $\operatorname{rch} 184$ & 0.901 & $\operatorname{rch} 184$ & 0.901 & $\operatorname{rch} 184$ & 0.901 \\
\hline rch189 & 0.451 & rch189 & 0.451 & $\operatorname{rch} 189$ & 0.451 \\
\hline $\operatorname{rch} 202$ & 0.192 & $\operatorname{rch} 202$ & 0.192 & $\operatorname{rch} 202$ & 0.192 \\
\hline rch204 & 0.4 & $\operatorname{rch} 204$ & 0.4 & $\operatorname{rch} 204$ & 0.4 \\
\hline $\operatorname{rch} 207$ & 1.4 & $\operatorname{rch} 207$ & 1.4 & $\operatorname{rch} 207$ & 1.4 \\
\hline $\operatorname{rch} 212$ & 0.99 & $\operatorname{rch} 212$ & 0.99 & $\operatorname{rch} 212$ & 0.99 \\
\hline $\operatorname{rch} 222$ & 0.501 & $\operatorname{rch} 222$ & 0.501 & $\operatorname{rch} 222$ & 0.501 \\
\hline $\operatorname{rch} 251$ & 2.3 & $\operatorname{rch} 251$ & 2.3 & $\operatorname{rch} 251$ & 2.3 \\
\hline $\operatorname{rch} 254$ & 1.12 & $\operatorname{rch} 254$ & 1.12 & $\operatorname{rch} 254$ & 1.16 \\
\hline- & - & - & - & $\operatorname{rch} 2541$ & 0.35 \\
\hline- & - & - & - & $\operatorname{rch} 255$ & 0.471 \\
\hline $\operatorname{rch} 259$ & 1.22 & $\operatorname{rch} 259$ & 1.22 & $\operatorname{rch} 259$ & 1.22 \\
\hline $\operatorname{rch} 260$ & 3.24 & $\operatorname{rch} 260$ & 3.24 & $\operatorname{rch} 260$ & 3.24 \\
\hline $\operatorname{rch} 262$ & 1.11 & $\operatorname{rch} 262$ & 1.11 & $\operatorname{rch} 262$ & 1.11 \\
\hline $\operatorname{rch} 263$ & 0.46 & $\operatorname{rch} 263$ & 0.46 & $\operatorname{rch} 263$ & 0.46 \\
\hline $\operatorname{rch} 265$ & 1.04 & $\operatorname{rch} 265$ & 1.04 & $\operatorname{rch} 265$ & 1.04 \\
\hline $\operatorname{rch} 266$ & 1.5 & $\operatorname{rch} 266$ & 1.5 & $\operatorname{rch} 266$ & 1.5 \\
\hline $\operatorname{rch} 267$ & 1.2 & $\operatorname{rch} 267$ & 1.2 & $\operatorname{rch} 267$ & 1.2 \\
\hline rchrun2671 & 1. & rchrun2671 & 1. & rchrun2671 & 1. \\
\hline
\end{tabular}

Table 2-1. Comparison of parameter values in different versions of the Great Basin carbonate and alluvial aquifer system groundwater model.-Continued

[Values rounded to three significant figures. Changes in parameter values are highlighted in red. - , parameter not in model version]

\begin{tabular}{|c|c|c|c|c|c|}
\hline \multicolumn{2}{|c|}{$\begin{array}{l}\text { GBCAAS v. } 1.0 \text { (Brooks and } \\
\text { others, 2014) }\end{array}$} & \multicolumn{2}{|c|}{$\begin{array}{l}\text { GBCAAS v. } 2.0 \text { (Stolp and } \\
\text { others, 2017) } \\
\end{array}$} & \multicolumn{2}{|c|}{ GBCAAS v. 3.0} \\
\hline $\begin{array}{l}\text { Parameter } \\
\text { name }\end{array}$ & $\begin{array}{l}\text { Parameter } \\
\text { value }\end{array}$ & $\begin{array}{l}\text { Parameter } \\
\text { name }\end{array}$ & $\begin{array}{l}\text { Parameter } \\
\text { value }\end{array}$ & $\begin{array}{l}\text { Parameter } \\
\text { name }\end{array}$ & $\begin{array}{l}\text { Parameter } \\
\text { value }\end{array}$ \\
\hline $\operatorname{rch} 270$ & 1.94 & $\operatorname{rch} 270$ & 1.94 & $\operatorname{rch} 270$ & 1.94 \\
\hline $\operatorname{rch} 272$ & 0.908 & $\operatorname{rch} 272$ & 0.908 & $\operatorname{rch} 272$ & 0.908 \\
\hline rchrun 272 & 1.33 & rchrun 272 & 1.33 & rchrun 272 & 1.33 \\
\hline - & - & rchrun 2721 & 66.5 & rchrun 2721 & 66.5 \\
\hline- & - & rchrun 2722 & 24.1 & rchrun 2722 & 24.1 \\
\hline $\mathrm{rch} 273$ & 1.47 & $\operatorname{rch} 273$ & 1.47 & $\operatorname{rch} 273$ & 1.47 \\
\hline rchimp273 & 0.5 & rchimp273 & 0.5 & rchimp273 & 0.5 \\
\hline - & - & rchimp2731 & 1.09 & rchimp2731 & 1.09 \\
\hline - & - & rchimp2737 & 1.08 & rchimp2737 & 1.08 \\
\hline- & - & $\operatorname{rch} 2735$ & 2.4 & $\operatorname{rch} 2735$ & 2.4 \\
\hline $\operatorname{rch} 275$ & 6.64 & $\operatorname{rch} 275$ & 6.64 & $\operatorname{rch} 275$ & 6.64 \\
\hline $\mathrm{rch} 280$ & 0.441 & $\operatorname{rch} 280$ & 0.441 & - & - \\
\hline $\operatorname{rch} 281$ & 1.21 & $\operatorname{rch} 281$ & 1.21 & $\operatorname{rch} 281$ & 1.08 \\
\hline - & - & - & - & $\operatorname{rch} 2812$ & 0.987 \\
\hline- & - & - & - & rchirr281 & 0.58 \\
\hline - & - & - & - & rchirr281B & 0.921 \\
\hline $\mathrm{rch} 282$ & 1.82 & $\operatorname{rch} 282$ & 1.82 & $\operatorname{rch} 282$ & 1.82 \\
\hline - & - & - & - & $\operatorname{rch} 2821$ & 1.21 \\
\hline $\operatorname{rch} 283$ & 1.03 & $\operatorname{rch} 283$ & 1.03 & $\operatorname{rch} 283$ & 1.07 \\
\hline $\mathrm{rch} 286$ & 1.46 & $\operatorname{rch} 286$ & 1.46 & $\operatorname{rch} 286$ & 1.44 \\
\hline- & - & - & - & $\operatorname{rch} 287$ & 1.85 \\
\hline rch364 & 1.33 & $\operatorname{rch} 364$ & 1.33 & $\operatorname{rch} 364$ & 1.33 \\
\hline rch999 & 0.099 & rch999 & 0.099 & rch999 & 0.099 \\
\hline rch9999 & 0.01 & rch9999 & 0.01 & rch9999 & 0.01 \\
\hline in_ha59 & 1. & in_ha59 & 1. & in_ha59 & 1. \\
\hline out_ha167 & 1. & out_ha167 & 1. & out_ha167 & 1. \\
\hline - & - & pumpage & 0.995 & pumpage273 & 0.995 \\
\hline - & - & - & - & PPsouth & 0.95 \\
\hline - & - & - & - & PPnorth & 0.901 \\
\hline UBFAU1_hk & 4.85 & UBFAU1_hk & 4.85 & UBFAU1_hk & 4.85 \\
\hline UBFAU12HK & 0.12 & UBFAU12HK & 0.12 & UBFAU12HK & 0.12 \\
\hline UBFAU13HK & 117. & UBFAU13HK & 117. & UBFAU13HK & 117. \\
\hline- & - & - & - & UBFAU14HK & 9.53 \\
\hline UBFAU2_hk & 0.811 & UBFAU2_hk & 0.811 & UBFAU2_hk & 0.811 \\
\hline UBFAU23hk & 0.191 & UBFAU23hk & 0.191 & UBFAU23hk & 0.191 \\
\hline UBFAU3_HK & 3.37 & UBFAU3_HK & 3.37 & UBFAU3_HK & 3.37 \\
\hline
\end{tabular}


Table 2-1. Comparison of parameter values in different versions of the Great Basin carbonate and alluvial aquifer system groundwater model.-Continued

[Values rounded to three significant figures. Changes in parameter values are highlighted in red. -, parameter not in model version]

\begin{tabular}{|c|c|c|c|c|c|}
\hline \multicolumn{2}{|c|}{$\begin{array}{c}\text { GBCAAS v. } 1.0 \text { (Brooks and } \\
\text { others, 2014) }\end{array}$} & \multicolumn{2}{|c|}{$\begin{array}{l}\text { GBCAAS v. } 2.0 \text { (Stolp and } \\
\text { others, 2017) }\end{array}$} & \multicolumn{2}{|c|}{ GBCAAS v. 3.0} \\
\hline $\begin{array}{l}\text { Parameter } \\
\text { name }\end{array}$ & $\begin{array}{l}\text { Parameter } \\
\text { value }\end{array}$ & $\begin{array}{l}\text { Parameter } \\
\text { name }\end{array}$ & $\begin{array}{l}\text { Parameter } \\
\text { value }\end{array}$ & $\begin{array}{l}\text { Parameter } \\
\text { name }\end{array}$ & $\begin{array}{c}\text { Parameter } \\
\text { value }\end{array}$ \\
\hline UBFAU31HK & 8.03 & UBFAU31HK & 8.03 & UBFAU31HK & 8.03 \\
\hline - & - & UBFAU32HK & 68.1 & UBFAU32HK & 68.1 \\
\hline UBFAU34HK & 1. & UBFAU34HK & 1. & UBFAU34HK & 1. \\
\hline UBFAU35HK & 38.8 & UBFAU35HK & 38.8 & UBFAU35HK & 38.8 \\
\hline UBFAU36HK & 14.7 & UBFAU36HK & 14.7 & UBFAU36HK & 14.7 \\
\hline UBFAU4_HK & 0.386 & UBFAU4_HK & 0.386 & UBFAU4_HK & 0.386 \\
\hline UBFAU41HK & 2.03 & UBFAU41HK & 2.03 & UBFAU41HK & 2.03 \\
\hline UBFAU45HK & 22.5 & UBFAU45HK & 22.5 & UBFAU45HK & 22.5 \\
\hline - & - & - & - & UBFAU46HK & 17.1 \\
\hline UBFAU48HK & 0.229 & UBFAU48HK & 0.229 & UBFAU48HK & 0.229 \\
\hline LBFAU1_HK & 0.042 & LBFAU1_HK & 0.042 & LBFAU1_HK & 0.042 \\
\hline- & - & - & - & LBFAU11HK & 0.096 \\
\hline LBFAU3_hk & 0.5 & LBFAU3_hk & 0.5 & LBFAU3_hk & 0.5 \\
\hline LBFAU4_HK & 0.3 & LBFAU4_HK & 0.3 & LBFAU4_HK & 0.3 \\
\hline LBFAU5_hk & 0.229 & LBFAU5_hk & 0.229 & LBFAU5_hk & 0.229 \\
\hline VU1_hk & 0.474 & VU1_hk & 0.474 & VU1_hk & 0.474 \\
\hline VU2_hk & 0.003 & VU2_hk & 0.003 & VU2_hk & 0.003 \\
\hline VU22hk & 1.57 & VU22hk & 1.57 & VU22hk & 1.57 \\
\hline VU5_hk & 0.083 & VU5_hk & 0.083 & VU5_hk & 0.083 \\
\hline TLCAU1_hk & 0.003 & TLCAU1_hk & 0.003 & TLCAU1_hk & 0.003 \\
\hline TLCAU2_hk & 0.05 & TLCAU2_hk & 0.05 & TLCAU2_hk & 0.06 \\
\hline TNCCU1_HK & 0.021 & TNCCU1_HK & 0.021 & TNCCU1_HK & 0.021 \\
\hline TNCCU2_hk & 0.002 & TNCCU2_hk & 0.002 & TNCCU2_hk & 0.002 \\
\hline TNCCU4_hk & 0.496 & TNCCU4_hk & 0.496 & TNCCU4_hk & 0.496 \\
\hline UCAU1_hk & 0.105 & UCAU1_hk & 0.105 & UCAU1_hk & 0.105 \\
\hline - & - & - & - & UCAU11hk & 0.042 \\
\hline UCAU12hk & 3.63 & UCAU12hk & 3.63 & UCAU12hk & 3.63 \\
\hline UCAU13hk & 0.004 & UCAU13hk & 0.004 & UCAU13hk & 0.004 \\
\hline UCAU14hk & 0.682 & UCAU14hk & 0.682 & UCAU14hk & 0.682 \\
\hline UCAU2_hk & 2.05 & UCAU2_hk & 2.05 & UCAU2_hk & 2.05 \\
\hline UCAU31hk & 0.001 & UCAU31hk & 0.001 & UCAU31hk & 0.001 \\
\hline UCAU5_hk & 0.378 & UCAU5_hk & 0.378 & UCAU5_hk & 0.378 \\
\hline USCU11hk & 0.1 & USCU11hk & 0.1 & USCU11hk & 0.1 \\
\hline USCU13HK & 0.001 & USCU13HK & 0.001 & USCU13HK & 0.001 \\
\hline USCU14hk & 0.004 & USCU14hk & 0.004 & USCU14hk & 0.004 \\
\hline LCAU412hk & 0.003 & LCAU412hk & 0.003 & LCAU412hk & 0.003 \\
\hline LCAU413hk & 5.65 & LCAU413hk & 5.65 & LCAU413hk & 5.65 \\
\hline LCAU414hk & 0.6 & LCAU414hk & 0.6 & LCAU414hk & 0.6 \\
\hline LCAU415hk & 0.364 & LCAU415hk & 0.364 & LCAU415hk & 0.364 \\
\hline LCAU417hk & 0.05 & LCAU417hk & 0.05 & LCAU417hk & 0.05 \\
\hline LCAU418hk & 0.001 & LCAU418hk & 0.001 & LCAU418hk & 0.001 \\
\hline LCAU42_hk & 1.24 & LCAU42_hk & 1.24 & LCAU42_hk & 1.24 \\
\hline
\end{tabular}

Table 2-1. Comparison of parameter values in different versions of the Great Basin carbonate and alluvial aquifer system groundwater model.-Continued

[Values rounded to three significant figures. Changes in parameter values are highlighted in red. - , parameter not in model version]

\begin{tabular}{|c|c|c|c|c|c|}
\hline \multicolumn{2}{|c|}{$\begin{array}{c}\text { GBCAAS v. } 1.0 \text { (Brooks and } \\
\text { others, 2014) }\end{array}$} & \multicolumn{2}{|c|}{$\begin{array}{l}\text { GBCAAS v. } 2.0 \text { (Stolp and } \\
\text { others, 2017) }\end{array}$} & \multicolumn{2}{|c|}{ GBCAAS v. 3.0} \\
\hline $\begin{array}{l}\text { Parameter } \\
\text { name }\end{array}$ & $\begin{array}{c}\text { Parameter } \\
\text { value }\end{array}$ & $\begin{array}{l}\text { Parameter } \\
\text { name }\end{array}$ & $\begin{array}{l}\text { Parameter } \\
\text { value }\end{array}$ & $\begin{array}{l}\text { Parameter } \\
\text { name }\end{array}$ & $\begin{array}{l}\text { Parameter } \\
\text { value }\end{array}$ \\
\hline LCAU421hk & 0.027 & LCAU421hk & 0.027 & LCAU421hk & 0.027 \\
\hline LCAU422hk & 0.07 & LCAU422hk & 0.07 & LCAU422hk & 0.07 \\
\hline LCAU423hk & 0.181 & LCAU423hk & 0.181 & LCAU423hk & 0.181 \\
\hline - & - & - & - & LCAU424hk & 0.012 \\
\hline LCAU43_hk & 0.008 & LCAU43_hk & 0.008 & LCAU43_hk & 0.008 \\
\hline LCAU51_HK & 1.4 & LCAU51_HK & 1.4 & LCAU51_HK & 1.4 \\
\hline LCAU511HK & 0.006 & LCAU511HK & 0.006 & LCAU511HK & 0.002 \\
\hline LCAU512hk & 15.4 & LCAU512hk & 15.4 & LCAU512hk & 15.4 \\
\hline LCAU513HK & 0.001 & LCAU513HK & 0.001 & LCAU513HK & 0.001 \\
\hline LCAU515hk & 0.013 & LCAU515hk & 0.013 & LCAU515hk & 0.013 \\
\hline LCAU516HK & 0.121 & LCAU516HK & 0.121 & LCAU516HK & 0.121 \\
\hline LCAU517HK & 0.686 & LCAU517HK & 0.686 & LCAU517HK & 0.686 \\
\hline LCAU519hk & 6.62 & LCAU519hk & 6.62 & LCAU519hk & 6.62 \\
\hline LCAU5111hk & 0.3 & LCAU5111hk & 0.3 & LCAU5111hk & 0.3 \\
\hline LCAU52_hk & 0.066 & LCAU52_hk & 0.066 & LCAU52_hk & 0.066 \\
\hline LCAU521hk & 0.751 & LCAU521hk & 0.751 & LCAU521hk & 0.681 \\
\hline LCAU522HK & 1.2 & LCAU522HK & 1.2 & LCAU522HK & 1.2 \\
\hline LCAU523hk & 0.005 & LCAU523hk & 0.005 & LCAU523hk & 0.005 \\
\hline LCAU524hk & 7. & LCAU524hk & 7. & LCAU524hk & 20.3 \\
\hline LCAU525hk & 0.104 & LCAU525hk & 0.104 & LCAU525hk & 0.104 \\
\hline LCAU53_HK & 2.48 & LCAU53_HK & 2.48 & LCAU53_HK & 2.48 \\
\hline LCAU536hk & 0.02 & LCAU536hk & 0.02 & LCAU536hk & 0.02 \\
\hline LCAU61_hk & 0.161 & LCAU61_hk & 0.161 & LCAU61_hk & 0.161 \\
\hline - & - & - & - & LCAU610hk & 8.35 \\
\hline LCAU611hk & 7.83 & LCAU611hk & 7.83 & LCAU611hk & 7.83 \\
\hline LCAU612HK & 1.4 & LCAU612HK & 1.4 & LCAU612HK & 1.4 \\
\hline LCAU613HK & 0.707 & LCAU613HK & 0.707 & LCAU613HK & 0.708 \\
\hline LCAU614HK & 0.065 & LCAU614HK & 0.065 & LCAU614HK & 0.065 \\
\hline LCAU615hk & 0.04 & LCAU615hk & 0.04 & LCAU615hk & 0.04 \\
\hline- & 1.99 & LCAU616HK & 1.99 & LCAU616HK & 1.99 \\
\hline LCAU618hk & 0.017 & LCAU618hk & 0.017 & LCAU618hk & 0.017 \\
\hline LCAU619hk & 31.6 & LCAU619hk & 31.6 & LCAU619hk & 35.5 \\
\hline LCAU71_HK & 0.061 & LCAU71_HK & 0.061 & LCAU71_HK & 0.061 \\
\hline LCAU81_hk & 4.03 & LCAU81_hk & 4.03 & LCAU81_hk & 4.03 \\
\hline LCAU811hk & 0.01 & LCAU811hk & 0.01 & LCAU811hk & 0.01 \\
\hline LCAU812hk & 2.51 & LCAU812hk & 2.51 & LCAU812hk & 2.51 \\
\hline NCCU1_hk & 0.002 & NCCU1_hk & 0.002 & NCCU1_hk & 0.002 \\
\hline NCCU11hk & 0.001 & NCCU11hk & 0.001 & NCCU11hk & 0.001 \\
\hline NCCU12HK & 0.005 & NCCU12HK & 0.005 & NCCU12HK & 0.005 \\
\hline NCCU13hk & 0.5 & NCCU13hk & 0.5 & NCCU13hk & 0.5 \\
\hline NCCU14hk & 0. & NCCU14hk & 0. & NCCU14hk & 0. \\
\hline NCCU15hk & 0.249 & NCCU15hk & 0.249 & NCCU15hk & 0.249 \\
\hline
\end{tabular}


Table 2-1. Comparison of parameter values in different versions of the Great Basin carbonate and alluvial aquifer system groundwater model.-Continued

[Values rounded to three significant figures. Changes in parameter values are highlighted in red. - , parameter not in model version]

\begin{tabular}{|c|c|c|c|c|c|}
\hline \multicolumn{2}{|c|}{$\begin{array}{l}\text { GBCAAS v. } 1.0 \text { (Brooks and } \\
\text { others, 2014) }\end{array}$} & \multicolumn{2}{|c|}{$\begin{array}{l}\text { GBCAAS v. } 2.0 \text { (Stolp and } \\
\text { others, 2017) }\end{array}$} & \multicolumn{2}{|c|}{ GBCAAS v. 3.0} \\
\hline $\begin{array}{l}\text { Parameter } \\
\text { name }\end{array}$ & $\begin{array}{l}\text { Parameter } \\
\text { value }\end{array}$ & $\begin{array}{l}\text { Parameter } \\
\text { name }\end{array}$ & $\begin{array}{l}\text { Parameter } \\
\text { value }\end{array}$ & $\begin{array}{l}\text { Parameter } \\
\text { name }\end{array}$ & $\begin{array}{c}\text { Parameter } \\
\text { value }\end{array}$ \\
\hline NCCU16hk & 019 & $\mathrm{NCCl}$ & 0.019 & NCCU16hk & 0.019 \\
\hline NCCU17hk & 8 & NCCU17hk & 88 & NCCU17hk & 0.008 \\
\hline NCCU110hk & 0.083 & NCCU110hk & 0.083 & NCCU110hk & 0.083 \\
\hline NCCU2_hk & 0.048 & NCCU2_hk & 0.048 & NCCU2_hk & 0.048 \\
\hline $\mathrm{NCCl}$ & 98 & $\mathrm{NCC}$ & 8 & NCCU21 & 0.198 \\
\hline NCCU23hk & 0.005 & NCCU23hk & 0.005 & NCCU231 & 0.005 \\
\hline NCCU24hk & 0.003 & NCCU24hk & 0.003 & NCCU24hk & 0.003 \\
\hline NCCU25hk & 0. & NCCU25hk & 0. & NCCU25hk & 0. \\
\hline- & - & NCCU26hk & 0.056 & NCCU26hk & 0.056 \\
\hline NCCU28hk & 0.307 & NCCU28hk & 0.307 & NCCU28hk & 0.307 \\
\hline NCCU29hk & 0.009 & NCCU29hk & 0.009 & NCCU29hk & 0.009 \\
\hline NCCU3_hk & 0.115 & NCCU3_hk & 0.115 & NCCU3_hk & 0.115 \\
\hline NCCU32h & 0.00 & $\mathrm{~N}$ & 4 & k & 0.00 \\
\hline NCCU33HK & 0.002 & NCCU33HK & 0.002 & NCCU33HK & 0.002 \\
\hline NCCU36hk & 0.011 & NCCU36hk & 0.011 & NCCU36hk & 0.011 \\
\hline bfau_vn & 10.7 & bfau_vn & 10.7 & bfau_vn & 10.7 \\
\hline playa_vn & 66.1 & playa_vn & 66.1 & playa_vn & 66.1 \\
\hline playa2vn & 987. & playa2vn & 987. & playa2vn & 987. \\
\hline rock_vn & 1. & rock_vn & 1. & rock_vn & 1. \\
\hline - & - & - & - & SpecStor & 0. \\
\hline- & - & - & - & sy_rock & 0.01 \\
\hline- & - & - & - & sy_fill & 0.074 \\
\hline- & - & - & - & sy3 & 0.03 \\
\hline et_beryl & 1.37 & et_beryl & 1.37 & et_beryl & 1.42 \\
\hline et_colorado & 0.953 & et_colorado & 0.953 & et_colorado & 0.953 \\
\hline et_deathval & 2. & et_deathval & 2. & et_deathval & 2. \\
\hline et_goshute & 1.94 & et_goshute & 1.94 & et_goshute & 1.94 \\
\hline
\end{tabular}

Table 2-1. Comparison of parameter values in different versions of the Great Basin carbonate and alluvial aquifer system groundwater model.-Continued

[Values rounded to three significant figures. Changes in parameter values are highlighted in red. -, parameter not in model version]

\begin{tabular}{|c|c|c|c|c|c|}
\hline \multicolumn{2}{|c|}{$\begin{array}{c}\text { GBCAAS v. } 1.0 \text { (Brooks and } \\
\text { others, 2014) }\end{array}$} & \multicolumn{2}{|c|}{$\begin{array}{l}\text { GBCAAS v. } 2.0 \text { (Stolp and } \\
\text { others, 2017) }\end{array}$} & \multicolumn{2}{|c|}{ GBCAAS v. 3.0} \\
\hline $\begin{array}{l}\text { Parameter } \\
\text { name }\end{array}$ & $\begin{array}{l}\text { Parameter } \\
\text { value }\end{array}$ & $\begin{array}{l}\text { Parameter } \\
\text { name }\end{array}$ & $\begin{array}{l}\text { Parameter } \\
\text { value }\end{array}$ & $\begin{array}{l}\text { Parameter } \\
\text { name }\end{array}$ & $\begin{array}{l}\text { Parameter } \\
\text { value }\end{array}$ \\
\hline et_gsldno & 0.982 & et_gsldno & 0.982 & et_gsldno & 0.982 \\
\hline et_gsldwest & 1.11 & et_gsldwest & 1.11 & et_gsldwest & 1.11 \\
\hline et_gslnorth & 2.5 & et_gslnorth & 2.5 & et_gslnorth & 2.5 \\
\hline et_gslsouth & 2. & et_gslsouth & 2. & et_gslsouth & 2. \\
\hline et265 & 1.5 & et265 & 1.5 & et 265 & 1.5 \\
\hline et_humboldt & 1.43 & et_humboldt & 1.43 & et_humboldt & 1.43 \\
\hline et_marshes & 1.01 & et_marshes & 1.01 & et_marshes & 1.01 \\
\hline et_railroad & 1.12 & et_railroad & 1.12 & et_railroad & 1.12 \\
\hline et_reese & 0.978 & et_reese & 0.978 & et_reese & 0.978 \\
\hline et_sevier & 2.22 & et_sevier & 2.22 & - & - \\
\hline- & - & - & - & EVT_parowan & 2.1 \\
\hline- & - & - & - & EVT1 & 1.02 \\
\hline - & - & - & - & EVT2 & 2.03 \\
\hline- & - & - & - & EVT4 & 4. \\
\hline et268 & 0.986 & et268 & 0.986 & et 268 & 0.986 \\
\hline et 272 & 1.3 & et 272 & 1.3 & et 272 & 1.3 \\
\hline discharge & 0.501 & discharge & 0.501 & discharge & 0.501 \\
\hline river & 50. & river & 50. & river & 50. \\
\hline- & - & river273 & 0.152 & river273 & 0.152 \\
\hline b_dv_n2 & $1.78 \mathrm{E}-7$ & b_dv_n2 & $1.78 \mathrm{E}-07$ & b_dv_n2 & $1.78 \mathrm{E}-07$ \\
\hline b_lvvsz & $1.07 \mathrm{E}-6$ & b_lvvsz & $1.07 \mathrm{E}-06$ & b_lvvsz & $1.07 \mathrm{E}-06$ \\
\hline b_deepck & $1.39 \mathrm{E}-7$ & b_deepck & $1.39 \mathrm{E}-07$ & b_deepck & $1.39 \mathrm{E}-07$ \\
\hline b_steptoe & $2.67 \mathrm{E}-7$ & b_steptoe & $2.67 \mathrm{E}-07$ & b_steptoe & $2.67 \mathrm{E}-07$ \\
\hline b_hfb1 & $1.00 \mathrm{E}-08$ & b_hfb1 & $1.00 \mathrm{E}-08$ & b_hfb1 & $1.00 \mathrm{E}-08$ \\
\hline b_hfb2 & $5.00 \mathrm{E}-07$ & b_hfb2 & $5.00 \mathrm{E}-07$ & b_hfb2 & $5.00 \mathrm{E}-07$ \\
\hline- & - & - & - & b_parowan & $1.54 \mathrm{E}-07$ \\
\hline b_spring & $1.00 \mathrm{E}-05$ & b_spring & $1.00 \mathrm{E}-05$ & b_spring & $1.00 \mathrm{E}-05$ \\
\hline
\end{tabular}


Table 2-2. Model zones, multiplier arrays, and parameter values and statistics for recharge and withdrawals in the GBCAAS v. 3.0 groundwater model, model focus area, Utah and Nevada.

[Data for parameters outside of the model focus area are available in Brooks (2017). All values rounded to two significant figures. Parameter value: dimensionless multiplier of the conceptual recharge rate defined by the model multiplier arrays or of the conceptual pumping rate defined by the Well Package. 95-percent confidence interval: 95 -percent linear confidence interval calculated by UCODE 2014 (Poeter and others, 2008, p. 174). Standard deviation: Calculated by UCODE 2014 (Poeter and others, 2008 , p. 174). Abbreviations: HA, hydrographic area; - , not applicable]

\begin{tabular}{|c|c|c|c|c|c|c|c|}
\hline \multirow{3}{*}{$\begin{array}{l}\text { Parameter } \\
\text { name }\end{array}$} & \multirow{3}{*}{$\begin{array}{l}\text { Model } \\
\text { recharge } \\
\text { zones }\end{array}$} & \multirow{3}{*}{ Model multiplier arrays } & \multirow{3}{*}{$\begin{array}{l}\text { Location by } \mathrm{HA} \\
\text { number }\end{array}$} & \multicolumn{4}{|c|}{ Model estimate of recharge parameter } \\
\hline & & & & \multirow[b]{2}{*}{ Parameter value } & \multicolumn{2}{|c|}{ 95-percent confidence interval } & \multirow[b]{2}{*}{ Standard deviation } \\
\hline & & & & & Low value & High value & \\
\hline rch184 & 184 & $\begin{array}{l}\text { rech_inplace } \\
\text { rech_runoff } \\
\text { rech_base }\end{array}$ & $\begin{array}{l}178 \mathrm{~A}, 179,184,185,186 \mathrm{~A} \\
186 \mathrm{~B}, 253,254,261 \mathrm{~A}\end{array}$ & 0.9 & 0.71 & 1.1 & 0.098 \\
\hline $\operatorname{rch} 202$ & 202 & $\begin{array}{l}\text { rech_inplace } \\
\text { rech_runoff } \\
\text { rech_base }\end{array}$ & $\begin{array}{l}171,181-184,198-206, \\
208-210,216-222,254,280\end{array}$ & 0.19 & 0.16 & 0.23 & 0.018 \\
\hline $\operatorname{rch} 254$ & 254 & $\begin{array}{l}\text { rech_inplace } \\
\text { rech_runoff } \\
\text { rech_base }\end{array}$ & $253,254,257,258$ & 1.2 & 0.94 & 1.4 & 0.11 \\
\hline $\operatorname{rch} 2541$ & 254 & $\begin{array}{l}\text { rech_inplace } \\
\text { rech_runoff } \\
\text { rech_base }\end{array}$ & $183,184,201,254,255$ & 0.35 & 0.21 & 0.49 & 0.072 \\
\hline $\operatorname{rch} 255$ & 255 & $\begin{array}{l}\text { rech_inplace } \\
\text { rech_runoff } \\
\text { rech_base }\end{array}$ & $222,254-257,280$ & 0.47 & 0.33 & 0.61 & 0.071 \\
\hline $\operatorname{rch} 266$ & 266 & $\begin{array}{l}\text { rech_inplace } \\
\text { rech_runoff } \\
\text { rech_base }\end{array}$ & $262,263,265,266,270,287$ & 1.5 & 1.2 & 1.8 & 0.14 \\
\hline $\operatorname{rch} 281$ & 281 & $\begin{array}{l}\text { rech_inplace } \\
\text { InplaceSP2 to Inplace SP16 } \\
\text { rech_runoff } \\
\text { rech_run2 to rech_run16 } \\
\text { rech_base }\end{array}$ & 281 & 1.1 & 0.51 & 1.6 & 0.29 \\
\hline $\operatorname{rch} 2812$ & 2812 & $\begin{array}{l}\text { rech_inplace } \\
\text { InplaceSP2 to Inplace SP16 } \\
\text { rech_runoff } \\
\text { rech_run2 to rech_run16 } \\
\text { rech_base }\end{array}$ & 281 & 0.99 & 0.21 & 1.8 & 0.4 \\
\hline rchirr281 & 2811 & $\begin{array}{l}\text { rech_run5 to rech_run } 16 \\
\text { rech_base }\end{array}$ & 281,282 & 0.58 & -0.02 & 1.2 & 0.31 \\
\hline rchirr281B & 2811 & $\begin{array}{l}\text { rech_runoff } \\
\text { rech_run2 to rech_run4 } \\
\text { rech_base }\end{array}$ & 281,282 & 0.92 & 0.31 & 1.5 & 0.31 \\
\hline $\operatorname{rch} 282$ & 282 & $\begin{array}{l}\text { rech_inplace } \\
\text { rech_runoff } \\
\text { rech_base }\end{array}$ & 282 & 1.8 & 1. & 2.6 & 0.42 \\
\hline $\operatorname{rch} 2821$ & 2821 & $\begin{array}{l}\text { rech_inplace } \\
\text { rech_runoff } \\
\text { rech_base }\end{array}$ & 280,282 & 1.2 & 0.35 & 2.1 & 0.44 \\
\hline $\operatorname{rch} 283$ & 283 & $\begin{array}{l}\text { rech_inplace } \\
\text { rech_runoff } \\
\text { rech_base }\end{array}$ & $256,283,284$ & 1.1 & 0.88 & 1.3 & 0.096 \\
\hline $\operatorname{rch} 286$ & 286 & $\begin{array}{l}\text { rech_inplace } \\
\text { rech_runoff } \\
\text { rech_base } \\
\text { rech_import }\end{array}$ & $257,258,283-287$ & 1.4 & 1.1 & 1.8 & 0.16 \\
\hline rch999 & 999 & $\begin{array}{l}\text { rech_inplace } \\
\text { rech_runoff } \\
\text { rech_base } \\
\text { rech_import }\end{array}$ & scattered & 0.099 & -0.2 & 0.4 & 0.15 \\
\hline rch9999 & 9999 & $\begin{array}{l}\text { rech_inplace } \\
\text { rech_runoff } \\
\text { rech_base } \\
\text { rech_import }\end{array}$ & scattered & 0.01 & -0.85 & 0.87 & 0.44 \\
\hline
\end{tabular}


Table 2-2. Model zones, multiplier arrays, and parameter values and statistics for recharge and withdrawals in the GBCAAS v. 3.0 groundwater model, model focus area, Utah and Nevada.-Continued

[Data for parameters outside of the model focus area are available in Brooks (2017). All values rounded to two significant figures. Parameter value: dimensionless multiplier of the conceptual recharge rate defined by the model multiplier arrays or of the conceptual pumping rate defined by the Well Package. 95-percent confidence interval: 95 -percent linear confidence interval calculated by UCODE_2014 (Poeter and others, 2008, p. 174). Standard deviation: Calculated by UCODE_2014 (Poeter and others, 2008, p. 174).

Abbreviations: HA, hydrographic area; - , not applicable]

\begin{tabular}{|c|c|c|c|c|c|c|c|}
\hline \multirow{3}{*}{$\begin{array}{l}\text { Parameter } \\
\text { name }\end{array}$} & \multirow{3}{*}{$\begin{array}{l}\text { Model } \\
\text { recharge } \\
\text { zones }\end{array}$} & \multirow{3}{*}{ Model multiplier arrays } & \multirow{3}{*}{$\begin{array}{l}\text { Location by HA } \\
\text { number }\end{array}$} & \multicolumn{4}{|c|}{ Model estimate of recharge parameter } \\
\hline & & & & \multirow[b]{2}{*}{ Parameter value } & \multicolumn{2}{|c|}{ 95-percent confidence interval } & \multirow[b]{2}{*}{ Standard deviation } \\
\hline & & & & & Low value & High value & \\
\hline PPnorth & - & $\begin{array}{l}\text { Wells withdrawals in Parowan } \\
\text { Valley (HA 281) }\end{array}$ & 281 & 0.9 & 0.2 & 1.6 & 0.36 \\
\hline PPsouth & - & $\begin{array}{l}\text { Wells withdrawals in Parowan } \\
\text { Valley (HA 281) }\end{array}$ & 281 & 0.95 & 0.5 & 1.4 & 0.23 \\
\hline
\end{tabular}

Table 2-3. Hydrogeologic zones, model zones, and parameter values and statistics for horizontal hydraulic conductivity of the confining units in the GBCAAS v. 3.0 groundwater model, model focus area, Utah and Nevada.

[Data for parameters outside of the model focus area are available in Brooks (2017). All values rounded to two significant figures. Hydraulic conductivity in feet per day. Zone code: hydrogeologic zone from Sweetkind and others (2011a). Model zone: zone number used in MODFLOW files. 95-percent confidence interval: 95-percent linear confidence interval as calculated by UCODE_2014 (Poeter and others, 2008, p. 174). Standard deviation of log values: calculated by UCODE_2014 (Poeter and others, 2008, p. 174).

Abbreviations: HK, horizontal hydraulic conductivity; NCCU, non-carbonate confining unit; USCU, upper siliciclastic confining unit]

\begin{tabular}{|c|c|c|c|c|c|c|c|c|}
\hline \multirow{3}{*}{ Zone code } & Danorintion of & & \multirow{3}{*}{$\begin{array}{l}\text { Model } \\
\text { zone }\end{array}$} & \multirow{3}{*}{$\begin{array}{l}\text { Model HK } \\
\text { parameter }\end{array}$} & \multicolumn{4}{|c|}{ Model estimate of hydraulic conductivity (rounded) } \\
\hline & Description of zone & $\begin{array}{l}\text { nyaraulic } \\
\text { conductivity }\end{array}$ & & & \multirow{2}{*}{$\begin{array}{l}\text { Parameter } \\
\text { value }\end{array}$} & \multicolumn{2}{|c|}{ 95-percent confidence interval } & \multirow{2}{*}{$\begin{array}{c}\text { Standard } \\
\text { deviation of log } \\
\text { values }\end{array}$} \\
\hline & \multicolumn{2}{|c|}{ (Modified from Sweetkind and others, 2011) } & & & & Low value & High value & \\
\hline \multirow[t]{6}{*}{ NCCU 1} & \multirow{6}{*}{$\begin{array}{l}\text { Late Proterozoic siliciclastic rocks such as } \\
\text { the Prospect Mountain Quartzite (north), and } \\
\text { Wood Canyon Formation/Stirling Quartzite } \\
\text { (south). Generally well-developed fracture } \\
\text { network, especially along bedding planes. } \\
\text { Clay interbeds can inhibit connectivity. }\end{array}$} & \multirow[t]{6}{*}{ Moderate } & 11 & nccu11hk & 0.00071 & 0.00045 & 0.0011 & 0.1 \\
\hline & & & 12 & nccu12hk & 0.0045 & 0.0029 & 0.007 & 0.099 \\
\hline & & & 13 & nccu13hk & 0.5 & 0.35 & 0.72 & 0.082 \\
\hline & & & 16 & nccu16hk & 0.018 & 0.009 & 0.038 & 0.16 \\
\hline & & & 17 & nccu17hk & 0.0085 & 0.0066 & 0.011 & 0.057 \\
\hline & & & 18 & nccu24hk & 0.0032 & 0.0023 & 0.0043 & 0.068 \\
\hline \multirow{5}{*}{ NCCU 2} & \multirow{5}{*}{$\begin{array}{l}\text { Foliated metamorphic rocks including } \\
\text { gneiss, schist, slate associated with highly } \\
\text { extended terranes and metamorphic core } \\
\text { complexes. Foliation prohibits development } \\
\text { of well-connected fracture network; matrix is } \\
\text { impermeable. }\end{array}$} & \multirow{5}{*}{ Low } & 2 & nccu2_hk & 0.048 & 0.03 & 0.079 & 0.11 \\
\hline & & & 22 & nccu3_hk & 0.11 & 0.09 & 0.15 & 0.055 \\
\hline & & & 23 & nccu23hk & 0.0053 & 0.0042 & 0.0068 & 0.054 \\
\hline & & & 24 & nccu24hk & 0.0032 & 0.0023 & 0.0043 & 0.068 \\
\hline & & & 28 & nccu28hk & 0.31 & 0.22 & 0.43 & 0.074 \\
\hline \multirow{5}{*}{ NCCU 3} & \multirow{5}{*}{$\begin{array}{l}\text { Plutonic (intrusive) rocks; inferred at } \\
\text { depth from projection of surface geology, } \\
\text { assumption that plutons underlie calderas, } \\
\text { and interpretation of magnetic and gravity } \\
\text { data. May support well-developed fracture } \\
\text { networks where at the surface or within } \\
\text { 1-kilometer of the surface; deeper intrusives } \\
\text { are probably less fractured. At depth, } \\
\text { especially beneath calderas and volcanic } \\
\text { centers, fracture permeability may be reduced } \\
\text { by quartz veins filling fractures or by clay } \\
\text { alteration along fracture walls. }\end{array}$} & \multirow{5}{*}{ Low-moderate } & 3 & nccu3_hk & 0.11 & 0.09 & 0.15 & 0.055 \\
\hline & & & 33 & nccu33hk & 0.0015 & 0.00076 & 0.003 & 0.15 \\
\hline & & & 34 & nccu17hk & 0.0085 & 0.0066 & 0.011 & 0.057 \\
\hline & & & 35 & nccu14hk & 0.00026 & 0.00013 & 0.00052 & 0.16 \\
\hline & & & 36 & nccu36hk & 0.011 & 0.0072 & 0.016 & 0.09 \\
\hline \multirow{2}{*}{ USCU } & \multirow{2}{*}{ Not delineated into zones } & \multirow{2}{*}{ Low } & 13 & uscu13hk & 0.0013 & 0.00064 & 0.0026 & 0.16 \\
\hline & & & 14 & uscu14hk & 0.0036 & 0.0019 & 0.0069 & 0.14 \\
\hline
\end{tabular}


Table 2-4. Hydrogeologic zones, model zones, and parameter values and statistics for horizontal hydraulic conductivity of the carbonate aquifer units in the GBCAAS v. 3.0 groundwater model, model focus area, Utah and Nevada.

[Data for parameters outside of the model focus area are available in Brooks (2017). All values rounded to two significant figures. Hydraulic conductivity in feet per day. Zone code: hydrogeologic zone from Brooks and others (2014, fig.A4-2) and Sweetkind and others (2011a). Model zone: zone number used in MODFLOW files. 95-percent confidence interval: 95-percent linear confidence interval as calculated by UCODE 2014 (Poeter and others, 2008, p. 174). Standard deviation of log values: calculated by UCODE 2014 (Poeter and others, 2008, p. 174). Abbreviations: HK, horizontal hydraulic conductivity; LCAU, lower carbonate aquifer unit; TLCAU, thrusted lower carbonate aquifer unit; UCAU, upper carbonate aquifer unit]

\begin{tabular}{|c|c|c|c|c|c|c|c|c|}
\hline \multirow{3}{*}{ Zone code } & Decorintion & & \multirow{3}{*}{$\begin{array}{l}\text { Model } \\
\text { zone }\end{array}$} & \multirow{3}{*}{$\begin{array}{l}\text { Model HK } \\
\text { parameter }\end{array}$} & \multicolumn{4}{|c|}{ Model estimate of hydraulic conductivity (rounded) } \\
\hline & Description or zoile & conductivity & & & \multirow{2}{*}{$\begin{array}{l}\text { Parameter } \\
\text { value }\end{array}$} & \multicolumn{2}{|c|}{ 95-percent confidence interval } & \multirow{2}{*}{$\begin{array}{c}\text { Standard } \\
\text { deviation of } \\
\text { log values }\end{array}$} \\
\hline & \multicolumn{2}{|l|}{ (Modified from Sweetkind and others, 2011) } & & & & Low value & High value & \\
\hline \multirow[t]{7}{*}{ LCAU 61} & \multirow{7}{*}{$\begin{array}{l}\text { Both lithologic and structural factors enhance } \\
\text { hydraulic conductivity. }\end{array}$} & \multirow[t]{7}{*}{ High } & 61 & lcau61_hk & 0.16 & 0.11 & 0.23 & 0.079 \\
\hline & & & 610 & lcau610hk & 8.4 & 4.4 & 16. & 0.14 \\
\hline & & & 613 & lcau613hk & 0.71 & 0.46 & 1.1 & 0.094 \\
\hline & & & 614 & lcau614hk & 0.065 & 0.042 & 0.1 & 0.096 \\
\hline & & & 615 & lcau615hk & 0.04 & 0.024 & 0.065 & 0.11 \\
\hline & & & 618 & lcau618hk & 0.017 & 0.0093 & 0.031 & 0.13 \\
\hline & & & 619 & lcau619hk & 36. & 13. & 95. & 0.22 \\
\hline \multirow{5}{*}{ LCAU 51} & \multirow{5}{*}{$\begin{array}{l}\text { This is the "base case" for Great Basin } \\
\text { carbonates. }\end{array}$} & \multirow{5}{*}{ Moderate } & 511 & lcau511hk & 0.0023 & 0.0013 & 0.0042 & 0.14 \\
\hline & & & 514 & lcau42_hk & 1.2 & 0.89 & 1.7 & 0.074 \\
\hline & & & 515 & lcau515hk & 0.013 & 0.01 & 0.016 & 0.051 \\
\hline & & & 516 & lcau516hk & 0.12 & 0.098 & 0.15 & 0.048 \\
\hline & & & 518 & lcau524hk & 20. & 14. & 30. & 0.087 \\
\hline \multirow{5}{*}{ LCAU 41} & \multirow{5}{*}{ Extension may disrupt aquifer continuity. } & \multirow{5}{*}{$\begin{array}{l}\text { Moderately } \\
\text { low }\end{array}$} & 414 & lcau414hk & 0.6 & 0.48 & 0.75 & 0.049 \\
\hline & & & 416 & lcau53_hk & 2.5 & 1.7 & 3.6 & 0.081 \\
\hline & & & 417 & lcau417hk & 0.05 & 0.036 & 0.069 & 0.071 \\
\hline & & & 419 & lcau42_hk & 1.2 & 0.89 & 1.7 & 0.074 \\
\hline & & & 4110 & lcau511hk & 0.0023 & 0.0013 & 0.0042 & 0.14 \\
\hline \multirow{3}{*}{ LCAU 52} & \multirow{3}{*}{$\begin{array}{l}\text { Pilot Shale reduces hydraulic conductivity below } \\
\text { "base case." }\end{array}$} & \multirow{3}{*}{$\begin{array}{l}\text { Moderately } \\
\text { low }\end{array}$} & 52 & lcau52_hk & 0.066 & 0.035 & 0.12 & 0.14 \\
\hline & & & 521 & lcau521hk & 0.68 & 0.39 & 1.2 & 0.12 \\
\hline & & & 524 & lcau524hk & 20. & 14. & 30. & 0.087 \\
\hline \multirow{3}{*}{ LCAU 53} & \multirow{3}{*}{$\begin{array}{l}\text { Thin bedded, silty carbonate reduces hydraulic } \\
\text { conductivity below "base case." }\end{array}$} & \multirow{3}{*}{$\begin{array}{l}\text { Moderately } \\
\text { low }\end{array}$} & 53 & lcau53_hk & 2.5 & 1.7 & 3.6 & 0.081 \\
\hline & & & 531 & lcau52_hk & 0.066 & 0.035 & 0.12 & 0.14 \\
\hline & & & 532 & lcau414hk & 0.6 & 0.48 & 0.75 & 0.049 \\
\hline \multirow{4}{*}{ LCAU 42} & \multirow{4}{*}{$\begin{array}{l}\text { Both lithologic and structural factors reduce } \\
\text { hydraulic conductivity. }\end{array}$} & \multirow{4}{*}{ Low } & 42 & lcau42_hk & 1.2 & 0.89 & 1.7 & 0.074 \\
\hline & & & 421 & lcau421hk & 0.027 & 0.014 & 0.054 & 0.15 \\
\hline & & & 423 & lcau423hk & 0.18 & 0.077 & 0.42 & 0.19 \\
\hline & & & 424 & lcau424hk & 0.012 & 0.0012 & 0.12 & 0.51 \\
\hline LCAU 71 & $\begin{array}{l}\text { Contact metamorphic may convert carbonate to } \\
\text { marble and reduce hydraulic conductivity. }\end{array}$ & Low & 71 & lcau71_hk & 0.061 & 0.044 & 0.085 & 0.073 \\
\hline LCAU 72 & $\begin{array}{l}\text { Lowest hydraulic conductivity. Both lithology } \\
\text { and structural factors reduce hydraulic conduc- } \\
\text { tivity. }\end{array}$ & Lowest & 72 & lcau71_hk & 0.061 & 0.044 & 0.085 & 0.073 \\
\hline LCAU 73 & $\begin{array}{l}\text { Lowest hydraulic conductivity. Both lithology } \\
\text { and structural factors reduce hydraulic conduc- } \\
\text { tivity. }\end{array}$ & Lowest & 73 & lcau71_hk & 0.061 & 0.044 & 0.085 & 0.073 \\
\hline TLCAU & Not reported separately from LCAU & $\begin{array}{l}\text { Not reported } \\
\text { separately } \\
\text { from LCAU }\end{array}$ & 2 & tlcau2_hk & 0.06 & 0.011 & 0.33 & 0.38 \\
\hline \multirow{2}{*}{ UCAU 1} & $\begin{array}{l}\text { Fractured carbonate rocks of Pennsylvanian- } \\
\text { Permian age that were deposited in shallow }\end{array}$ & Higl & 1 & ucau1_hk & 0.11 & 0.067 & 0.16 & 0.099 \\
\hline & $\begin{array}{l}\text { well-developed fracture network; in thick upper } \\
\text { Paleozoic carbonate rocks. }\end{array}$ & Ingit & 12 & ucau12hk & 3.6 & 2.1 & 6.1 & 0.12 \\
\hline
\end{tabular}


Table 2-4. Hydrogeologic zones, model zones, and parameter values and statistics for horizontal hydraulic conductivity of the carbonate aquifer units in the GBCAAS v. 3.0 groundwater model, model focus area, Utah and Nevada._Continued

[Data for parameters outside of the model focus area are available in Brooks (2017). All values rounded to two significant figures. Hydraulic conductivity in feet per day. Zone code: hydrogeologic zone from Brooks and others (2014, fig.A4-2) and Sweetkind and others (2011a). Model zone: zone number used in MODFLOW files. 95-percent confidence interval: 95-percent linear confidence interval as calculated by UCODE_ 2014 (Poeter and others, 2008, p. 174). Standard deviation of log values: calculated by UCODE_2014 (Poeter and others, 2008, p. 174). Abbreviations: HK, horizontal hydraulic conductivity; LCAU, lower carbonate aquifer unit; TLCAU, thrusted lower carbonate aquifer unit; UCAU, upper carbonate aquifer unit]

\begin{tabular}{|c|c|c|c|c|c|c|c|c|}
\hline \multirow{3}{*}{ Zone code } & \multirow{3}{*}{$\begin{array}{c}\text { Description of zone } \\
\text { (Modified from Sweetkind and others, 2011) }\end{array}$} & \multirow{3}{*}{$\begin{array}{c}\text { Relative } \\
\text { hydraulic } \\
\text { conductivity }\end{array}$} & \multirow{3}{*}{$\begin{array}{c}\text { Model } \\
\text { zone }\end{array}$} & \multirow{3}{*}{$\begin{array}{c}\text { Model HK } \\
\text { parameter }\end{array}$} & \multicolumn{4}{|c|}{ Model estimate of hydraulic conductivity (rounded) } \\
\hline & & & & & \multirow{2}{*}{$\begin{array}{l}\text { Parameter } \\
\text { value }\end{array}$} & \multicolumn{2}{|c|}{ 95-percent confidence interval } & \multirow{2}{*}{$\begin{array}{c}\text { Standard } \\
\text { deviation of } \\
\text { log values }\end{array}$} \\
\hline & & & & & & Low value & High value & \\
\hline \multirow{2}{*}{ UCAU 2} & \multirow{2}{*}{$\begin{array}{l}\text { Very thick, silty carbonate rocks deposited in the } \\
\text { Oquirrh basin during Pennsylvanian time. Gen- } \\
\text { erally well-developed fracture network; in thick } \\
\text { upper Paleozoic carbonate rocks. Generally } \\
\text { more silty than the shallow-water carbonates of } \\
\text { zone 1; may reduce permeability somewhat. }\end{array}$} & \multirow{2}{*}{$\begin{array}{l}\text { Moderate to } \\
\text { high }\end{array}$} & 2 & ucau2_hk & 2.1 & 0.87 & 4.8 & 0.19 \\
\hline & & & 21 & ucau1_hk & 0.11 & 0.067 & 0.16 & 0.099 \\
\hline UCAU 3 & $\begin{array}{l}\text { Continental siliciclastic rocks and other Upper } \\
\text { Paleozoic and Mesozoic rocks of the Colorado } \\
\text { Plateau. Section is much thinner than in zones } \\
1 \text { and } 2 \text { and contains Triassic siliciclastic rocks, } \\
\text { such as Chinle and Moenkopi Formations, that } \\
\text { are shaly. }\end{array}$ & Moderate & 3 & ucau1_hk & 0.11 & 0.067 & 0.16 & 0.099 \\
\hline UCAU 4 & $\begin{array}{l}\text { Carbonate rocks deposited in deep water, gener- } \\
\text { ally thin bedded, shaly Pennsylvanian-Permian } \\
\text { rocks. Thin bedding and fine-grained interbeds } \\
\text { may preclude development of good fracture } \\
\text { network and reduce overall permeability. }\end{array}$ & $\begin{array}{l}\text { Low to } \\
\text { moderate }\end{array}$ & 4 & ucau1_hk & 0.11 & 0.067 & 0.16 & 0.099 \\
\hline
\end{tabular}

Table 2-5. Hydrogeologic zones, model zones, and parameter values and statistics for horizontal hydraulic conductivity of the volcanic and basin-fill units in the GBCAAS v. 3.0 groundwater model, model focus area, Utah and Nevada.

[Data for parameters outside of the model focus area are available in Brooks (2017). All values rounded to two signficant figures. Hydraulic conductivity in feet per day. Zone code: hydrogeologic zone from Sweetkind and others, 2011. Model zone: zone number used in MODFLOW files. 95-percent confidence interval: 95-percent linear confidence interval as calculated by UCODE_2014 (Poeter and others, 2008, p. 174). Standard deviation of log values: calculated by UCODE 2014 (Poeter and others, 2008, p. 174). Abbreviations: HK, horizontal hydraulic conductivity; VU, volcanic unit; LBFAU, lower basin-fill aquifer unit; UBFAU, upper basin-fill aquifer unit]

\begin{tabular}{|c|c|c|c|c|c|c|c|c|}
\hline \multirow{3}{*}{ Zone code } & & & \multirow{3}{*}{$\begin{array}{l}\text { Model } \\
\text { zone }\end{array}$} & \multirow{3}{*}{$\begin{array}{l}\text { Model HK } \\
\text { parameter }\end{array}$} & \multicolumn{4}{|c|}{ Model estimate of hydraulic conductivity (rounded) } \\
\hline & Description or zone & $\begin{array}{l}\text { nyaraulic } \\
\text { conductivity }\end{array}$ & & & \multirow{2}{*}{$\begin{array}{l}\text { Parameter } \\
\text { value }\end{array}$} & \multicolumn{2}{|c|}{ 95-percent confidence interval } & \multirow{2}{*}{$\begin{array}{l}\text { Standard } \\
\text { deviation of } \\
\text { log values }\end{array}$} \\
\hline & \multicolumn{2}{|l|}{ (Modified from Sweetkind and others, 2011) } & & & & Low value & High value & \\
\hline \multirow[t]{2}{*}{ VU 1} & Welded ash-flow tuff, generally in thick se- & High & 1 & vul_hk & 0.47 & 0.37 & 0.61 & 0.055 \\
\hline & $\begin{array}{l}\text { work. Permeability may be reduced somewhat } \\
\text { inside calderas due to lithologic heterogeneity. }\end{array}$ & & 12 & vu2_hk & 0.003 & 0.002 & 0.007 & 0.15 \\
\hline VU 2 & $\begin{array}{l}\text { Local lava flows; areas of rhyolite to andesite } \\
\text { lava flows that form localized accumulations, } \\
\text { not widespread sheets. Can be highly fractured, } \\
\text { but fracture pattern is typically disorganized and } \\
\text { fractures are short. }\end{array}$ & $\begin{array}{l}\text { Moderate to } \\
\text { high }\end{array}$ & 2 & vu2_hk & 0.003 & 0.002 & 0.007 & 0.15 \\
\hline VU 3 & $\begin{array}{l}\text { Prevolcanic basins; areas where significant } \\
\text { amounts of sedimentary rocks may underlie } \\
\text { outcrops of volcanic rocks. Consists of early } \\
\text { Cenozoic lake beds and generally fine-grained } \\
\text { deposits; can include some sandy or coarse- } \\
\text { grained material. }\end{array}$ & Moderate & 31 & vu5_hk & 0.083 & 0.06 & 0.11 & 0.072 \\
\hline VU 4 & Shallow or outcropping basalt. & Moderate & 4 & vul_hk & 0.47 & 0.37 & 0.61 & 0.055 \\
\hline VU 5 & Mesozoic and Cenozoic sedimentary rocks. & $\begin{array}{l}\text { Low to } \\
\text { moderate }\end{array}$ & & & & & & \\
\hline VU 6 & $\begin{array}{l}\text { Heterogenous rocks, includes tuff, rhyolite to } \\
\text { basalt lava flows, and interbedded sedimentary } \\
\text { rocks. Heterogeneity may reduce overall perme- } \\
\text { ability. }\end{array}$ & $\begin{array}{l}\text { Low to } \\
\text { moderate }\end{array}$ & 5 & vu5_hk & 0.083 & 0.06 & 0.11 & 0.072 \\
\hline
\end{tabular}


Table 2-5. Hydrogeologic zones, model zones, and parameter values and statistics for horizontal hydraulic conductivity of the volcanic and basin fill units in the GBCAAS v. 3.0 groundwater model, model focus area, Utah and Nevada.-Continued

[Data for parameters outside of the model focus area are available in Brooks (2017). All values rounded to two signficant figures. Hydraulic conductivity in feet per day. Zone code: hydrogeologic zone from Sweetkind and others, 2011. Model zone: zone number used in MODFLOW files. 95-percent confidence interval: 95-percent linear confidence interval as calculated by UCODE 2014 (Poeter and others, 2008, p. 174). Standard deviation of log values: calculated by UCODE 2014 (Poeter and others, 2008, p. 174). Abbreviations: HK, horizontal hydraulic conductivity; VU, volcanic unit; LBFAU, lower basin-fill aquifer unit; UBFAU, upper basin-fill aquifer unit]

\begin{tabular}{|c|c|c|c|c|c|c|c|c|}
\hline \multirow{3}{*}{ Zone code } & \multirow{3}{*}{$\begin{array}{c}\text { Description of zone } \\
\text { (Modified from Sweetkind and others, } 2011\end{array}$} & \multirow{3}{*}{$\begin{array}{c}\text { Relative } \\
\text { hydraulic } \\
\text { conductivity }\end{array}$} & \multirow{3}{*}{$\begin{array}{l}\text { Model } \\
\text { zone }\end{array}$} & \multirow{3}{*}{$\begin{array}{l}\text { Model HK } \\
\text { parameter }\end{array}$} & \multicolumn{4}{|c|}{ Model estimate of hydraulic conductivity (rounded) } \\
\hline & & & & & \multirow{2}{*}{$\begin{array}{l}\text { Parameter } \\
\text { value }\end{array}$} & \multicolumn{2}{|c|}{ 95-percent confidence interval } & \multirow{2}{*}{$\begin{array}{c}\text { Standard } \\
\text { deviation of } \\
\text { log values }\end{array}$} \\
\hline & & & & & & Low value & High value & \\
\hline \multirow{2}{*}{ VU 7} & \multirow{2}{*}{$\begin{array}{l}\text { Intracaldera ash-flow tuff and other rocks related } \\
\text { to caldera collapse. Permeability of volcanic } \\
\text { rocks may be reduced inside calderas. Unit has } \\
\text { the potential to be hydrothermally altered. }\end{array}$} & \multirow{2}{*}{$\begin{array}{l}\text { Moderate, } \\
\text { variable }\end{array}$} & 7 & vu2_hk & 0.003 & 0.002 & 0.007 & 0.15 \\
\hline & & & 71 & vul_hk & 0.47 & 0.37 & 0.61 & 0.055 \\
\hline \multirow{2}{*}{ LBFAU 1} & \multirow{2}{*}{$\begin{array}{l}\text { Welded ash-flow tuff; thick sequences that fill } \\
\text { the bottoms of Cenozoic basins within and } \\
\text { surrounding volcanic fields. Generally well- } \\
\text { developed fracture network. Permeability may } \\
\text { be reduced somewhat inside calderas because of } \\
\text { lithologic heterogeneity. }\end{array}$} & \multirow{2}{*}{ High } & 1 & lbfau1_hk & 0.042 & 0.007 & 0.26 & 0.4 \\
\hline & & & 11 & lbfau11hk & 0.096 & 0.008 & 1.2 & 0.56 \\
\hline \multirow{2}{*}{ LBFAU 2} & \multirow{2}{*}{$\begin{array}{l}\text { Intracaldera ash-flow tuff and other rocks, where } \\
\text { calderas extend from mountain ranges into } \\
\text { intervening valleys. Permeability of volcanic } \\
\text { rocks may be reduced inside calderas. Unit has } \\
\text { the potential to be hydrothermally altered. }\end{array}$} & \multirow{2}{*}{$\begin{array}{l}\text { Moderate, } \\
\text { variable }\end{array}$} & 2 & vu2_hk & 0.003 & 0.002 & 0.007 & 0.15 \\
\hline & & & 21 & vul_hk & 0.47 & 0.37 & 0.61 & 0.055 \\
\hline LBFAU 3 & $\begin{array}{l}\text { Local lava flows; areas of more localized lava } \\
\text { flows, generally andesite or rhyolite, that fill } \\
\text { the bottoms of Cenozoic basins within and } \\
\text { surrounding volcanic centers. Can be highly } \\
\text { fractured, but fracture pattern is typically } \\
\text { disorganized and fractures are short. }\end{array}$ & $\begin{array}{l}\text { Moderate to } \\
\text { high }\end{array}$ & 3 & lbfau3_hk & 0.5 & 0.13 & 1.9 & 0.3 \\
\hline LBFAU 4 & $\begin{array}{l}\text { Prevolcanic Cenozoic sedimentary rocks; } \\
\text { generally lake-bed and other fine-grained } \\
\text { deposits, but can include some sandy or coarse- } \\
\text { grained material. }\end{array}$ & Moderate & 4 & lbfau4_hk & 0.3 & 0.091 & 0.99 & 0.26 \\
\hline LBFAU 5 & $\begin{array}{l}\text { Generally coarse-grained basin fill. Deep burial } \\
\text { and cementation may reduce permeability. }\end{array}$ & Moderate & 5 & lbfau5_hk & 0.23 & 0.1 & 0.52 & 0.18 \\
\hline \multirow{2}{*}{ UBFAU 1} & \multirow{2}{*}{$\begin{array}{l}\text { Near-surface basalt flows, mostly thin flows } \\
\text { overlying or within coarse-grained basin fill. } \\
\text { Basalts can have high fracture permeability and } \\
\text { permeable zones at contacts between flows. } \\
\text { Local alteration may reduce permeability. }\end{array}$} & \multirow{2}{*}{ Moderate } & 11 & ubfau31hk & 8. & 6.8 & 9.5 & 0.038 \\
\hline & & & 14 & ubfau14hk & 9.5 & 5. & 18 & 0.14 \\
\hline UBFAU 2 & $\begin{array}{l}\text { Prevolcanic and synvolcanic sediments. Early } \\
\text { Cenozoic lake beds and generally fine-grained } \\
\text { deposits. }\end{array}$ & $\begin{array}{l}\text { Moderate to } \\
\text { low }\end{array}$ & 2 & ubfau2_hk & 0.81 & 0.52 & 1.3 & 0.099 \\
\hline \multirow{5}{*}{ UBFAU 3} & \multirow{5}{*}{$\begin{array}{l}\text { Areas of Pleistocene lakes and modern playas } \\
\text { consisting of fine-grained surficial sediments. }\end{array}$} & \multirow{5}{*}{$\begin{array}{l}\text { Moderate to } \\
\text { low }\end{array}$} & 3 & ubfau3_hk & 3.4 & 2.6 & 4.4 & 0.059 \\
\hline & & & 31 & ubfau31hk & 8. & 6.8 & 9.5 & 0.038 \\
\hline & & & 34 & ubfau34hk & 1. & 0.71 & 1.4 & 0.075 \\
\hline & & & 35 & ubfau35hk & 39. & 29. & 53. & 0.068 \\
\hline & & & 36 & ubfau36hk & 15. & 8.3 & 26. & 0.13 \\
\hline \multirow{8}{*}{ UBFAU 4} & \multirow{8}{*}{$\begin{array}{l}\text { Undivided basin fill. Inferred to be late Cenozoic } \\
\text { alluvial sands and gravels. }\end{array}$} & \multirow{8}{*}{ Moderate } & 4 & ubfau4_hk & 0.39 & 0.3 & 0.5 & 0.059 \\
\hline & & & 41 & ubfau41hk & 2. & 1.6 & 2.6 & 0.055 \\
\hline & & & 42 & ubfau31hk & 8. & 6.8 & 9.5 & 0.038 \\
\hline & & & 43 & ubfau35hk & 39. & 29. & 53. & 0.068 \\
\hline & & & 45 & ubfau45hk & 22. & 18. & 28. & 0.052 \\
\hline & & & 46 & ubfau46hk & 17. & 11. & 26. & 0.093 \\
\hline & & & 48 & ubfau48hk & 0.23 & 0.15 & 0.36 & 0.099 \\
\hline & & & 49 & ubfau13hk & 120. & 49. & 280 . & 0.2 \\
\hline
\end{tabular}


Table 2-6. Parameter values and statistics for horizontal-to-vertical anisotropy of all hydrogeologic units in the GBCAAS v. 3.0 groundwater model, model focus area, Utah and Nevada.

[Data for parameters outside of the model focus area are available in Brooks (2017). All values rounded to two significant figures. Parameter values are dimensionless. Model zone: zone number used in MODFLOW files. 95-percent confidence interval: 95-percent linear confidence interval as calculated by UCODE 2014 (Poeter and others, 2008, p. 174). Standard deviation of log values: calculated by UCODE_2014 (Poeter and others, 2008 , p. 174). Abbreviations: HGU, hydrogeologic unit; NCCU, non-carbonate confining unit; LCAU, lower carbonate aquifer unit; TLCAU, thrusted lower carbonate aquifer unit; USCU, upper siliciclastic confining unit; UCAU, upper carbonate aquifer unit; VU, volcanic unit; LBFAU, lower basin-fill aquifer unit; UBFAU, upper basin-fill aquifer unit]

\begin{tabular}{|c|c|c|c|c|c|c|}
\hline \multirow{3}{*}{$\begin{array}{l}\text { Parameter } \\
\text { name }\end{array}$} & \multirow{3}{*}{$\begin{array}{c}\text { Hydrogeologic } \\
\text { unit }\end{array}$} & \multirow{3}{*}{ Model zone } & \multicolumn{4}{|c|}{ Model estimate of horizontal-to-vertical anisotropy (rounded) } \\
\hline & & & \multirow{2}{*}{$\begin{array}{l}\text { Parameter } \\
\text { value }\end{array}$} & \multicolumn{2}{|c|}{ 95-percent confidence interval } & \multirow{2}{*}{$\begin{array}{c}\text { Standard } \\
\text { deviation o } \\
\text { log values }\end{array}$} \\
\hline & & & & Low value & High value & \\
\hline \multirow{11}{*}{ rock_vn } & $\mathrm{NCCU}$ & All & \multirow{11}{*}{1} & \multirow{11}{*}{0.69} & \multirow{11}{*}{1.5} & \multirow{11}{*}{0.083} \\
\hline & LCAU & All & & & & \\
\hline & TLCAU & All & & & & \\
\hline & USCU & All & & & & \\
\hline & UCAU & All & & & & \\
\hline & VU & $\begin{array}{l}\text { All in model } \\
\text { focus area }\end{array}$ & & & & \\
\hline & LBFAU & 1 & & & & \\
\hline & LBFAU & 11 & & & & \\
\hline & LBFAU & 2 & & & & \\
\hline & LBFAU & 21 & & & & \\
\hline & LBFAU & 3 & & & & \\
\hline \multirow{13}{*}{ bfau_vn } & LBFAU & 4 & \multirow{13}{*}{11} & \multirow{13}{*}{4.8} & \multirow{13}{*}{24} & \multirow{13}{*}{0.18} \\
\hline & LBFAU & 5 & & & & \\
\hline & UBFAU & 11 & & & & \\
\hline & UBFAU & 14 & & & & \\
\hline & UBFAU & 2 & & & & \\
\hline & UBFAU & 4 & & & & \\
\hline & UBFAU & 41 & & & & \\
\hline & UBFAU & 42 & & & & \\
\hline & UBFAU & 43 & & & & \\
\hline & UBFAU & 45 & & & & \\
\hline & UBFAU & 46 & & & & \\
\hline & UBFAU & 48 & & & & \\
\hline & UBFAU & 49 & & & & \\
\hline \multirow{5}{*}{ playa_vn } & UBFAU & 3 & \multirow{5}{*}{66} & \multirow{5}{*}{36} & \multirow{5}{*}{120} & \multirow{5}{*}{0.13} \\
\hline & UBFAU & 31 & & & & \\
\hline & UBFAU & 34 & & & & \\
\hline & UBFAU & 35 & & & & \\
\hline & UBFAU & 36 & & & & \\
\hline
\end{tabular}


Table 2-7. Parameter values and statistics for evapotranspiration conductance or rate multiplier, drain leakance, and river conductivity in the GBCAAS v. 3.0 groundwater model, model focus area, Utah and Nevada.

[Data for parameters outside of the model focus area are available in Brooks (2017). All values rounded to two significant figures. Evapotranspiration (et) parameters: dimensionless multipliers of the conductance. Evapotranspiration (EVT) parameters: dimensionless multipliers of the maximum evapotranspiration rate. Discharge parameter: per day for drains, feet per day for rivers. River parameter: feet per day. 95-percent confidence interval: 95-percent linear confidence interval as calculated by UCODE 2014 (Poeter and others, 2008, p. 174). Standard deviation of log values: Calculated by UCODE 2014 (Poeter and others, 2008, p. 174). Abbreviation: -, not applicable]

\begin{tabular}{|c|c|c|c|c|c|c|}
\hline \multirow{3}{*}{$\begin{array}{l}\text { Parameter } \\
\text { name }\end{array}$} & \multirow{3}{*}{$\begin{array}{c}\text { Hydrogeologic area } \\
\text { number }\end{array}$} & \multicolumn{4}{|c|}{ Model estimate of parameter } & \multirow{3}{*}{$\begin{array}{l}\text { Standard } \\
\text { deviation }\end{array}$} \\
\hline & & \multirow{2}{*}{$\begin{array}{l}\text { Parameter } \\
\text { value }\end{array}$} & \multicolumn{2}{|c|}{ 95-percent confidence interval } & \multirow{2}{*}{$\begin{array}{c}\text { Standard } \\
\text { deviation of log } \\
\text { values }\end{array}$} & \\
\hline & & & Low value & High value & & \\
\hline et_beryl & 280 to 284 & 1.4 & 1. & 2. & 0.075 & - \\
\hline et_gsldwest & $\begin{array}{c}184,185,253,254 \\
257,258,259,261 \mathrm{~A}\end{array}$ & 1.1 & 0.93 & 1.3 & 0.039 & - \\
\hline $\begin{array}{l}\mathrm{EVT}_{-} \\
\text {parowan }\end{array}$ & 281 & 2.1 & 1.2 & 3. & - & 0.44 \\
\hline EVT1 & 287 & 1. & 0.44 & 1.6 & - & 0.29 \\
\hline EVT2 & $254,257,286$ & 2. & 1.3 & 2.8 & - & 0.37 \\
\hline EVT4 & $254,285,287$ & 4. & 3.1 & 4.9 & - & 0.46 \\
\hline discharge & multiple & 0.5 & 0.22 & 1.2 & 0.19 & - \\
\hline river & multiple & 50. & 0.39 & 6,400 & 1.1 & - \\
\hline
\end{tabular}

Table 2-8. Parameter values and statistics for the hydraulic conductivity of horizontal-flow barriers in the GBCAAS v. 3.0 groundwater model, model focus area, Utah and Nevada.

[Data for parameters outside of the model focus area are available in Brooks (2017). All values rounded to two significant figures. Hydraulic conductivity of horizontal-flow barrier in feet per day. 95-percent confidence interval: 95-percent linear confidence interval as calculated by UCODE_2014 (Poeter and others, 2008, p. 174). Standard deviation of log values: calculated by UCODE_2014 (Poeter and others, 2008, p. 174)]

\begin{tabular}{|c|c|c|c|c|}
\hline \multirow{3}{*}{ Parameter name } & \multicolumn{4}{|c|}{ Model estimate of hydraulic conductivity of horizontal-flow barrier } \\
\hline & \multirow{2}{*}{ Parameter value } & \multicolumn{2}{|c|}{ 95-percent confidence interval } & \multirow{2}{*}{$\begin{array}{c}\text { Standard deviation of } \\
\text { log values }\end{array}$} \\
\hline & & Low value & High value & \\
\hline b_hfb1 & $1.0 \mathrm{E}-08$ & $1.3 \mathrm{E}-10$ & 7.9E-07 & 0.97 \\
\hline b_hfb2 & $5.0 \mathrm{E}-07$ & $1.7 \mathrm{E}-08$ & $1.5 \mathrm{E}-05$ & 0.75 \\
\hline b_deepck & $1.4 \mathrm{E}-07$ & $6.2 \mathrm{E}-08$ & $3.1 \mathrm{E}-07$ & 0.18 \\
\hline b_parowan & $1.5 \mathrm{E}-07$ & $6.8 \mathrm{E}-11$ & $3.5 \mathrm{E}-04$ & 1.70 \\
\hline
\end{tabular}

Table 2-9. Parameter values and statistics for storage properties in the GBCAAS v. 3.0 groundwater model, model focus area, Utah and Nevada.

[Data for parameters outside of the model focus area are available in Brooks (2017). All values rounded to two significant figures. Specific yield (SY) parameters are dimensionlesss. Specific storage in per foot. 95-percent confidence interval: 95-percent linear confidence interval as calculated by UCODE_2014 (Poeter and others, 2008, p. 174). Standard deviation of log values: calculated by UCODE_2014 (Poeter and others, 2008, p. 174)]

\begin{tabular}{|c|c|c|c|c|c|}
\hline \multirow{3}{*}{$\begin{array}{l}\text { Parameter } \\
\text { name }\end{array}$} & \multirow{3}{*}{ Hydrogeologic unit } & \multicolumn{4}{|c|}{ Model estimate of parameter } \\
\hline & & \multirow{2}{*}{$\begin{array}{c}\text { Parameter } \\
\text { value, in feet } \\
\text { per day }\end{array}$} & \multicolumn{2}{|c|}{ 95-percent confidence interval } & \multirow{2}{*}{$\begin{array}{l}\text { Standard } \\
\text { deviation }\end{array}$} \\
\hline & & & $\begin{array}{l}\text { Low value, in } \\
\text { feet per day }\end{array}$ & $\begin{array}{l}\text { High value, in } \\
\text { feet per day }\end{array}$ & \\
\hline sy_fill & Most basin fill & 0.074 & 0.014 & 0.4 & 0.37 \\
\hline sy_rock & All rock units & 0.0099 & 0.00046 & 0.21 & 0.68 \\
\hline sy3 & $\begin{array}{l}\text { Basin fill in southern } \\
\text { Parowan Valley, Utah }\end{array}$ & 0.03 & 0.013 & 0.07 & 0.19 \\
\hline SpecStor & All & $1.20 \mathrm{E}-07$ & $6.60 \mathrm{E}-11$ & 0.00022 & 1.7 \\
\hline
\end{tabular}


For additional information, contact:

Director, Utah Water Science Center U.S. Geological Survey

2329 West Orton Circle

Salt Lake City, UT 84119-2047

801 908-5000

http://ut.water.usgs.gov/ 



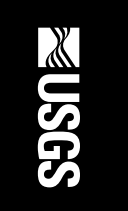

